University of Rhode Island

DigitalCommons@URI

Open Access Master's Theses

1972

\title{
Selected Portrayals of Mau Mau
}

Mary Anne Tilton

University of Rhode Island

Follow this and additional works at: https://digitalcommons.uri.edu/theses

\section{Recommended Citation}

Tilton, Mary Anne, "Selected Portrayals of Mau Mau" (1972). Open Access Master's Theses. Paper 1802. https://digitalcommons.uri.edu/theses/1802

This Thesis is brought to you for free and open access by DigitalCommons@URI. It has been accepted for inclusion in Open Access Master's Theses by an authorized administrator of DigitalCommons@URI. For more information, please contact digitalcommons-group@uri.edu. 
SELECTED PORTPAYALS OF MAU MAL

\author{
$3 Y$ \\ MARY ANNE TIETON
}

A THESIS SUBYITIED IN PARTIL FUIFILIMEMT OF THE REQUIREMENAS FOR THE DEEREE OF

MASTER OF ARTS

$I N$

H ISTOK

UNIVEASITY OF RHODE ISLAND

$\pm 97:$ 


\section{ABSTRACT}

The general public seldom, if ever, has access to government documents until many years after an event. The public's atticudes and ideas are molded by exposure to various points of view and interpretations expressed in novels, personal memoirs, and newspaper accounts. For many years the interpretations of the causes, the growth, and the activities of the African revolutionary group known as Mau Mau in Kenya have been shaped by novels and personal memoirs written by Americans, Europeans, and white Kenyans. Generally, these persons were opposed to Mau Mali. In recent years, especially since Kenyan independence in 1963, more novels and personal memoirs witten by black kenyans involved in Mau Mau or having knowledge of it have been published. Only by examining selected writings of both groups may one have some approximate concept of this very important event in modern history. Personal memoirs and novels concerning Mau Mai writter by both groups have been selected. There is no attempt to examine all personal memoirs or novels. In examining each work, the author's nationality and the publication date are noted. Each author's interpretation concerning the background, causes, activities, leadership, results, and nature of the Mau Mau is examined. 
Each author's concoptualisation of Mau Mau--its development, causes, tactics--is greatly affected by his background, his educational, sociological, and more particularly, his racial background. Differences in racial background explain the basic misunderstandings, points of view, attitudes, and interest. There were basically two points of view--that of the white, i.e., the white settler, the European, and the American on the one hand, and that of the black Kenyan, on the other. The blacks' points of view were not afforded exposure through personal memoirs, novels, movies, television news broadcasts, although the whites' were. Access to media and the media themselves were controlied dy whites. The whites cuncentrated on the horror of the Mau Mau in order to rationalize their own behavior and that of their government. The blacks riay have violence as the only means that would convey to the wirites the blacks' feelings and ideas. Tha blacks felt that only their skin color prevented them from participating in the white society, government, and economy. The blacks were utilizing force to bring about change while the whites were utilizing force in an effort to maintain their status quo. 
TABLE OF CONTENTS

CHAFTER

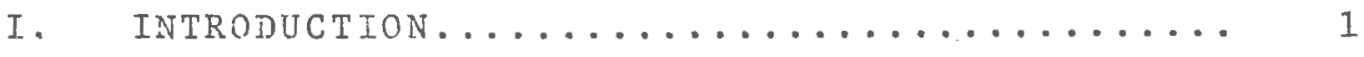
CHAPIER

II. HISTORICAL BACKGROUND TO THE MAU MAU REVOLT 6 CHAPTER

III. WHITE PERSONAL MEMOIRS ............... 32 CHAPTER.

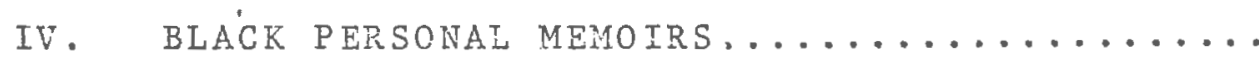
CHAPTER

V. WHITE NOVELS................................. 113 CHAPTER

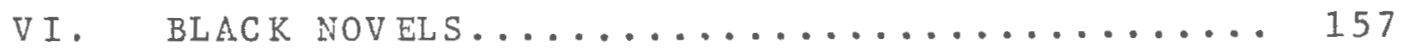
CHAPTER

VII. CONCLUSIONS....................... 183 BIBLIOGRAPHY ........................... 197 


\section{INTRODUCTION}

The African continent was the most highly colonized area in tha world diring the twentieth century until most of the European colonies achieved independence in the decades of the 1950's and the 1960's. Vestiges of colonization are still evident in Africa, the most striking examples being the Portuguese colonies of Angola and Mozambique. Some colonies have acquired independence through violence; in other instances the transition has been accompifshed through careful structuring and education. In still other instances, independence has been granted with only a little preparation and with the desire to avoid violence.

In the case of Kenya, two points immediately come to mind. During the decade of the $1950^{\prime} \mathrm{s}$, Kenya was the scene of the bloody, violent "Mau Mau" uprising. Secondly, since the revolt, Kenya has acquired the reputation of having one of the most stable governments in Africa. Although Britain and her cclonial governmenta have seen many disturbances since World War II, the Mau Mau revolt seems to have been the most publicized and the most violent. 
Kenya Colony became an independent nation and a member of the British Commonwealth of liations on December 12, 1953. Jomo Kenyatta, as Prime Minister, headed the government of the independent nation at its inception. The following year when Kenya became a republic, Kenyatta became ics president in which capacity he has continued to serve. October 23, 1952--only a little more than eleven years before Kenya became an independent nation-the white settler government of Kenya Colory headed by Sir Evelyn Baring declared a State of Emergency. The government had come to believe that an insurrection against the settlers and the government was being pianned by certain elemente of the Africin population and that this plan was being executed gradual1y. jomo kenyatta was one of the first to be arrested, then tried and imprisoned under the provisions of the Declaration. The government incorrectly assumed that by imprisoning kenyatta, the alleged leader of what came to be called the Mau Mau, the revolt would cease. In fact, however, his imprisonment may have contributed to its growth because Kenyatta was a most respected and educated African, a revered member of the Kikuyu tribe. During the whoie of the twentieth century the Kikuyu tribe was the largest and most highly educated tribe in kenya. It remained in most direct and constant contact with the European settlers. The government 
believed that most of the rebellious activity was being organized by the kikuyu. Although almost all active combat between government forces and Mau Mau ceased by 1956 , the government did not lift many restrictions imposed by the Declaration of Emergency until the 1960's. Jomo Kenyatta was not raleased from detention until 1961.

Kenya's history in the twentieth century has been considered mainly in light of its relationship with Britain and its settlers. There have been several explanations For Great Britain's initial involvement in East Africa. For example, it may be explained as an actempt to prevent complete German acquisicion of the area. That is not to say that British explorers, businessmen, missionaries, and anti-slave crusaders were not in East Africa during the nineteenth century. Until the artificial boundaries demarking Kenya, Uganda, and Tanganika were agreed upon by Great Britain and Germany in the 1880's, Kenya as a political, geographical, and sociological unit did not exist. Later the boundaries were redrawn to their present arrangement.

Kenya, to the east, faced the Indian Ocean. Tanzania bordered kenya to the south. Uganda was to the west of Kenya, and Ethiopia and Somalia were to the north. of all these countries in East Africa, Kenya was the only one which experienced such an uprising by the African population. 
Undoubtedly, this was partially attributable to the fact that Renya possessed the 1argest European population. In adition, this population was concentrated in certain fertile areas of the colony, relatively accessible to rail transport.

The purpose of this study is not to determine and analyze the causes of the Mau Mau revolt. Selected novels and personal memoirs written by Americans, Europeans, and European settlers on the one hand and by Africans on the other will be examined. In examining these works, the points of reference will be the causes of the Mau Mau revolt and the reactions to it as expressed by the authors. Until Kenyan independence was granted, the world was exposed almost without exception to the ideas and attitudes held by whites. The information about the Mau Mau revolt which has made and continues to make an impression on the world was not on 1 y disseminated through news media but also through movies, novels, and personal memoirs. The public has seen Rock Hudson stunned upon learning that his brother-in-law had been killed and his pregnant sister maimed by the violent Mau Mau in the screen version of Robert Ruark's Something of Value. This film also has been shown on television several times. In this manner, the image of the Mar Mau uprisIng has been fashioned. Before proceeding with an examination of the various novels and peisonal memoirs, it is 
necessary to investigate the hiscorical background to the decade of the $1950^{\prime} \mathrm{s}$. This will enable the reader to better appreciate the views of the authors cited. 
Through the centuries, material and intellectual developments in Africa have contributed to the evolution of Western civilization. Europe psychologically, geographically, and inteliectually was re-introduced to this "Dark Sontinent" during the fifteenth century with the Portuguese voyages of exploration for routes to the Far East. Various ports on the African coast were utilized as refueling stations by Portugal and other European rations which became involved in the rush to the Far East. Gradually, after the sixteenth sentury, these stopping points lost importarce for the European nations, until the nineteenth century when Africa became one of the major areas of European colonization Foilowing pachs set by the explorers, missionaries, and traders. The partition of Africa by the European countries was essentially the result of the appearance of Belgium and Germany who

...had not praviously shown any interest in the continent. It was this that upset the pre-existing balance of power and influence and precipitated a state of interrational hysteria in which all the powers 
rushed to stake claims to political sovereignty and to bargain with each other for recogrition in this or that region. 1

In East Africa the writings and traveis of explorermissionary Dr. David Livingstone revealed the existence of the cruelties of East African slave trade. Livingstone emphasized the need for penetration of the area by missionaries and traders to rid the area of the slave trade. Up until 1885, the Rritish government believed it was necessary to avoid direct commitments. However, with the growing interest of France, Belgium, and Germany in East Africa and with the establishment of a German protectorate over Tanganyika, the British government took more direct control of Uganda. As a rasult of assuming Uganda as a protectorate, the British government had to establisin a settled administration and to pay for services. This meant that the resources of the country had to be developed. To improve communications, a railway, started in 1896, was built from the port of Mombasa on the Indian Ocean to Lake Victoria through the East African Protectorate later called Kenya Colony. The building of the railway was the beginning of British involvement in Kenya, although European

${ }^{1}$ Roland 0liver and J.D. Fage, A Short History of Africa (Baltimore: Penguin Books, 1962) p.182. 
explorers and a few missionaries had penetrated the interior previously.

With the realization that plans for ugandan commercial development were not to mature, Great Britain became increasingly involved in the affairs of Kenya. European settlement in the fertile and climatieally comfortable regions of Kenya was encouraged. Eurodeans were to provide technolcgical ard comercial kionledge to develop the agricultural potential of the area. With the growing involvement of the British government and of the Europeans in Kenya, changes within Kenya were certain to accelerate. From the 1880's until 1963, when Kenya became an independent naijuil within the British Comontealth, there were a number of serious crises in the relationship of the Africans and Europeans in Kenya. These crises were to culminate in the declaration of the State of Emergency and the Mau Mau uprising. In order to understand the Mau Mau uprising, it is necessary to examine the background and the causes of its development, by examining the history of certain economic, social, and political developments.

In Kenya, immediately before the British arrival in the nineteenth century, there were a number of events which led to restlessness. There was a decline in Masai power, a rise in Nandi influence, and increased assertiveness on the part of the kikuyu. The agricultural tribes 
wera coming into conflict over land with pastorialists. ${ }^{2}$ During the later half of the rineteenth certury, Kenya was plagued by epidemics of rinderpest, pleuro-preumonia, and smallpox, and by a three-year famine (1897-1899). As a result of these disasters, the balance of power between the tribes was altered. The tribes were unable to occupy all tribai land actively. ${ }^{3}$ Ail these circumstances were to affect the British control in Fast Africa. The British were able to occlipy some lands which were not being actively utillzed. They were also able to initiate and exercise some control of the Africans because some traditional tribal structures had been altered temporarily or were in a state of flux. The tribes were generally rot able to resist British interference for they were neither united from within nor from without. During the last two decades of the nineteenth century, East Africans sought to meet the demands of the Europeans. New arrangements in the African social, economic, and political organizations were instituted. These arrangements eventually developed into points

${ }^{2}$ Car1 G. Rosberg, Jr. and John Nottingham, The Myth of "Mau Mau": Nationalism in Kenya (New York: Frederick A. Praegar, 1966), p.7.

${ }^{3}$ Vincent Harlow and E. M. Chilver, ed., History of East Africa, II (Oxford: Clarendon Press, 1965), p.4. 
of conflict between Africans and Europeass. By 1920, several devejopments independently and cumulatively in the relatiorship of Africans and Europeans were leading to the growth of African nationalism. These included: primary African resistance to pacification; widespread African opposition to colonization; missionary activity; European settlement and the beginning of land ailienation; the growth of Nairobi as an urban center; mobilization of Africans for World War I; and the establishment of settlement-dominated political institutions. ${ }^{4}$.

The Imperial British East African Company concentrated primarily on developing the commercial potential of Jganda. A railrogi was built between the coast and Uganda. Along the developed line of transportation, the IBEAC estabIished depots which were to provide food and other necessities. In 1890, when the IBEAC pressured depots in south Kikuyu to be self-sufficient, difficulties developed. The Kikuyu did not want to be subservient to the Europeans. Although there were military expeditions aginst the Kikuyu, the Kikuyu, by avoiding an overall crushing defeat, never officially surrendered to tha Europeans. 5

\footnotetext{
4Rosberg and Nottingham, "Mau Mau", pp.1-7. ${ }^{5}$ Ibi.d., pp. 13-16.
} 
Western education provided by the missions was conceived by young Africans to be a means by which to gain power. Many young men had become frustrated because they were unable to gain tribal influence which was held by the elders. The elders accepted the control of the colonial power, while the young men refused it. These young men were to develop and participate in political organizations which were beyond the traditional influence of elders. This situation created tensions within the tribes and between the tribes and the Europeans. 6

The development cf African nationalism in Kenya was directed against the white settler. European settlers had shaped the social, economic, and political development of Kenya Colony. Since the railway to Uganda had to pay for itself, government policy encouraged European settlement which could develop an economy based on the export of cash crops. As a result, European settlers were to create a "white man's country". All governmental policies and European practices were devoted to that end. 7

Nineteen hundred seven saw the establishment of the a11-European Legislative Council. There was a corresponding increase in European non-official strength which

$$
\begin{aligned}
& { }^{6} \text { Ibid., p. } 17 . \\
& { }^{7 \text { Ibjd. }}, \text { PP. } 18-19 .
\end{aligned}
$$


had a greater hold in developing poilcies concerning such things as land, education, and labor. "A colonial state was being established in which the interests of European settlers were paramount." The primary goal of trie administration was the growth of a prospercus white settlement. In this economy the role of the Africans was primarily that of wage earner, for it was assumed that the Africans would be more productive working for European settlers than working for themselves and that the Airicars would become more rapidly "civilized" by comirg into direct contact vith Europeans. 8 Since the European settlers needed a Iabor force, they convinced the government that the Africans should have to pay a tax. Because the Africans could only obtain money to pay the tax by working for Europeans, the Europeans would then be guaranteed the labor force needed to produce cash crops for export, e.g. coffee and tea, 9 as well as freedom from African competition in producing cash crops. 10 After World War I, European farmers, wishing to increase their production of cash crops, demanded more labor. In order to control the labor supply, each African male sixteen years of age or older was required to have a

$$
\begin{aligned}
& { }^{8} \text { Ibid., pp. } 20-21 . \\
& { }^{9} \text { Ibid., p. } 21 . \\
& 10_{\text {Harlow and Chilver, History of East Africa, II, }}
\end{aligned}
$$
p. 336 . 
Kipande (a registration certificate). This African registration card was also used to control tax payment and desertion from European farms. ${ }^{1}$ The growth of Nairobi as an urban center on the edge of Kikuyu territory was important in the complicated relationship between the Europeans and the Africans. This rapidly expanding city planned for the European and Indian population attracted many Europeans. Nairobi became a reminder to the Kikuyu "...that the tenure of their own lands under the colonial system was highly insecure."12 In spite of this or because of this, Nairobi became the fount and focus of African politics In Kenya.13

During the First World War, Africans were drafted Into service in the British army, especially into the Carrier Corps. This experience was to increase the growing consciousness that the world was larger than the tribe. The Africans began to realize the effectiveness of organization.14 While with the British troops in Africa and other parts of the world, the Africans developed a greater appreciation and understanding of their position vis-a-vis the

11 Ib1d., p...354.

12 Rosberg and Nottingham, "Mau Mau, " p. 23.

${ }^{13}$ Ibid., p. 26.

14 Ibid., p. 26. 
Europeans in Kenya. In addition, they realized the importance of the extreme fertility of the lands alienated in Kenya by the settlers. Much land in Africa was not fertile. Indeed, most of Kenya is not a fertile country. Two-thirds of the country is desert. Therefore, the fertile areas became overcrowded with agricultural tribes who were restricted in their growing of a cash crop, e.g. coffee.15 Among the African population, fear over loss of land was at the bottom of most of the insecurity and sense of injustice which played so great a part in the African response to European impact. For the Kikuyu, land seemed traditionally to have had a deeper significance than for most other East African peoples. Their land system was usually known as the githaka system. A githaka is a plot of land owned jointly by the members of a small localized lineage, the mberi, the basic unit of rikuyu society. The Kikuyu moved through their wooded country from north to south arriving in what is now kiambu only towards the end of the last century. ${ }^{16}$ By the time the first white settlers came at the beginning of the century, many of these kikuyu had moved north again or had died because of the various epidemics and disasters, bui they did not relinquish their

\footnotetext{
15 Harlow and Chilver, History of East Africa, II, p. 338 . 16 Ibid., pp. 338-39.
} 
title to this lard. Since the kikuyu were not there, the Europeans did not think that the land was claimed. Some was alienated with no opposition and some was forcibly acquired.17 The settlers and the government alienated those lands which were fertile, especially those valuable for coffee. Those fertile lands in the vicinity of Nairobi were alienated. Many Kikuyu opined that alienation caused overcrowding and the destruction of land and life. One European claimed that this was a convenient political myth perpetrated by the Kikuyu. 18

It is pertinent at this point to mention the growth of the population in the kikuyu reserves. In i902, there were 452,000 peopie (254 per square mile); by 1931, 489,000 (283 per square mile); and in $1948,745,000$ (ca. 300 per square mile). The high density in south and central kikuyuland was largely a consequence of the growth of Nairobi, with its opportunities for wage labor and for selling cash crops. As a result of overpopulation on their reserves, there was emigration from the reserves into the towns, into European held land as squatters, and into forest land. 19

17Irarlow and Chilver, History of East Africa, II, p.339. ${ }^{18}$ Ibid., p. 340 . ${ }^{19}$ Ibid., pp. 345-47. 
Due to the political system of the various tribes in Kenya, the British government decided to employ the system of native administration based on the use of appointed authorities rather than traditional rative chiefs. In almost every tribe, local government was in the hands either of the heads of small clans and lineages (as in Luo and Luhya) or of local councils composed of elders in an ageset system (as in Kikuyu, Kamba, and the pastoral NiloHamitic groups). These systems of government had serious disadvantages from the viewpoint of the central government. The heads oi clans and lineages and the members of councils exercised jurisdiction over very small groups, and the sanctions behind their authority were usualy religious. Elders were chosen by genealogical positions, by age, or as members of an age group. Elders could not exercise authority over persons not traditionally members of the particular kinship or local groups concerned. It was difficult to widen the scope of authority. 20 The British government felt that in order to exercise its control, it was necessary to appoint chiefs and headmen as representatives of the government in the tribe. 21 The government also provided for the establishment of Local Native Councils which were to be concerned

$$
\begin{aligned}
& 20 \text { Ibid., DD. 348-49. } \\
& 21 \text { Ibid., p. } 349 .
\end{aligned}
$$


with local problems, collection of rates, and taxation.22 The administration of justice was often hampered by the governmental destruction of the traditional sanctions in the tribe. These problems were often compificat conflicts of chiefs, traditional elders, and councils with the young educated men who wanted positions in the $10 \mathrm{c} 1$ administrative system.23 By 1920 , settlers further consolidated their power by having European members elected to over one-third of the thirty-one positions on the Legislative Council, and by having Kenya become a colony. During this year, 4,560 more square miles were alienated. 24

At this time, the gradually developing African leadersilp started questioning the "paramountcy" of. European interests. The Africans began to feel changes which were sociological in origin. In urban areas, problems included wages, living and working conditions, and the EuropeanIndian conflict. In rural areas, the points of conflict included the government alienation of African land, the poll tax, the recruitment of labor for Europeans, and local government administration, especially the government appointment of chiefs and headmen.25 After 1920, Africans began

$$
\begin{aligned}
& 22 \text { Ibid., p. } 350 . \\
& 23 \text { Ibid., Pp. } 351-52 . \\
& 24 \text { Rosberg and Nottingham, "Mau Mau, " p. } 33 . \\
& 25 \text { Ibid., p. } 35 .
\end{aligned}
$$


to realize that only by a change of European atiltudes and policies would the African situation improve. Therefore, it was necessary to convince the Europeans of the necessity of change. The Africans alone would not be able to bring about change. By 1920 , the Africans had realized that they had an enemy against whom they would assert what they regarded as tineir rights. 26

By 1921, the East African Association lead by Harry Thuku was established and became politically active when wages generally were cut. 27 The East African Association "...tended to reject fundamental premises of white rule." 28 Because of his political activities, Thuku was arrested and deported. While demonstrating against Thuki's arrest, twenty-five Africans were shot and killed. On Thuku's return to Kenya in 1930 he becane a moderate.29

Approzimately 1921, perhaps earlier, the Kikuyu Association (one year later renamed Young Kikuyu Association) was established in order to secure alienated land. The p. 354 .

26Harlow and Chilver, History of East Africa, II, 27 Rosberg and Nottingham, "Mau Mau," pp. 36-37. 28 Ibid., p. 43 .

${ }^{29}$ Harlow and Chilver, History of East Africa, II, p. 357 . 
Kikuyu Association "...accepted the colony's basic poiltical structure... and sought only its modification and reform." 30 The British government had professed a desire to have the colony directed in the interests of the Africans. In 1923, the Devonshire White Paper, while attempting to settle the European-Indian conflict in Kenya, declared that African interests were paramount. However, this policy was never effectively incorporated into the Kenya government's attitudes and actions, because of the control of the political structure by the Kenya settlers. 31

In 1925, the Kikiyu Central Association, formed in mid-1924 and led by Joseph Kangethe and Jeșe Kariuki, peitioned the jovernor for the abolition of the limitations on African agricultural production, for the dissemination of laws of the colony in Kikuyu, and for the selection of a chief to represent interests of all kikuyu, as well as the liberation of Harry Thuku. Nineteen twenty-five was a year of change in the ruling generation set. This traditional system of government was clearly incompatible with the new one of government supported chiefs and headmen. Hostility grew between the elders who held government authority and who wished to maintain tribal tradition, and the younger men

30 Rosberg and Nottingham, "Mau Mau," pp. 40-43. $31_{\text {Ibid., p. } 67 .}$ 
who wanted education and the benefits of modern progress. The paradox, of course, ras in the fact that at this juncture it was the elders who wished to remain with government authority, who were going against tribal tradition, and the younger men who wished to retain it. 32 Although in 1932 Harry Thuku became president of the Kikuyu Central Association as a moderate, he left after much wrangling. In I935, he founded the Kikuyu Provincial Association which offered cooperation with the government. 33 After 1935, the KCA assumed a most powerful position, by reviring its newspaper, Muiguthania, which opposed government projects unfavorable to the Kikuyu or which might alienate more Iand. The KCA became involved in problems oi several other tribes and the Mombasa dock strike of 1939. In May, 1940, it was declared illegal and its leaders were arrested as being seditious. 34 Jomo Kenyatta became general secretary of KCA in 1927 and became the first editor of Muiguthanla. In 1929 , KCA leaders chose him to be a representative to the British government in London to present their (the African and especial1y Kikuyu) grievances concerning land and labor,

\footnotetext{
32 Harlow and Chilver, History of East Africa, II, pp. $358-59$.
}

$$
\begin{aligned}
& 33 \text { Ibid., p. } 367 . \\
& 34 \text { Ibid., p. } 368 .
\end{aligned}
$$


educational advancement and also "...direct African representation of the Legislativa Councii."35 After conferring with several British government officials and seeing that nothing was settled, he visited the European continent and Russia. Kenyatta returned to Kenya in the fall, 1930. In 1931, the KCA sent Kenyatta back to London to represent the Kikuyu before the Parliamentary Joint Comittee on Closer Union in East Africa. Although Kenyatta was late, Chief Kainange, a representative of Kenya's colonial administration, presented before the committee many of the points desired by the Kikuyu and KCA. ${ }^{36}$

Kenyatta did not return to Kenya until 1946. During his stay in Engiand, he attended college and worked in various capacities. While studying for a diploma in anthropology, he wrote several papers which formed the basis for his famous study of the Kikuyu, Facing Mount Kenya. In Facing Mount Kenya, Kenyatta called for the examination of the tribal importance of female circumcision and of the development of "Watu wa Mungu" (Feople of God--prophets) after the conflict concerning female circumcision developed. Some Europeans claimed that Eacing Mount Kenya was a plan for revolt and for eventual domination of Kenya by the Kikuyu. 37

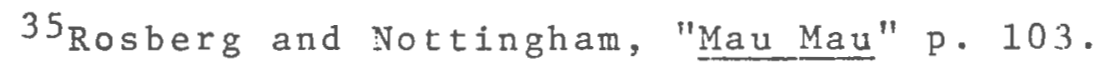
36 Ib1d., p. 140 . 37 Ib1d., pp . 133-34. 
During his stay in England Kenyatta replied to an article in The Times concerning "Uingest among Kikuyu Natives" commencing

... with all public-spirited men of my tribe...I regard with considerable uneasiness the policy which is being advocated by certain influential people, both in Kenya and in this country, of further alienating our land from us, for the use of non-natives, in conjunction with attempts to abolish wholesale our tribal customs. ...The KCA... is not a subversive organization. Its object is to help the Kiliuyu to improve himself as a Mu-Kikuyu--not to ape the foreigner. 38

In 1931, a Parliamentary committee recommended that the Kenya Land Commision should examine the question of land alienation and the land claims of Africans. In general, the Kikuyu wanted:

The repeal of the 1915 Crowr Lands Crdinance, compensation for githaka land that had been aiienated for European settlenent, control of land to be placed in the hands of Kikuyu councils, and the provision of more Iand for the greatiy increased population. 39

Although 60,000 acres of Kikuyu land had been alienated, the Commission recommended only 21,000 acres compensation, for it felt the Kikuyu had already received land as partial compensation. Three hundred and fifty to four hundred square miles at Yatta were allocated for the future expansion. "The general effect of the Commission's recommendations was to institutionalize the tribally and racially organized land

${ }^{38}$ George De1f, Jomo Kenvatta Towards Truth About "the Light of Kenva" (Garden City, New York: Doubleday and Co., Inc., 1961), p. 69 .

${ }^{39}$ Rosberg and Nottingham, "Mau Mau, "p. 155. 
system that had gradualiy developed in Renya since the turn of the century."40 A token compensation was paid for claims in the White fighlands for this area was to become an exclusive reserve for Europeans.

Conflicts are bound to come about as a result of charges when cre culture is exposed to another which is attempting to control it. There were conflicts in the changing situation of the Kikuyu. The Kikuyu feared further alienation of land and destruction of tribal customs. There were conflicts between Kikuyu tribal and political associations and Christian missions which controlled the education. These conflicts were "crystallized" in the female circumcision controversy of 1929.

Tribal custom included circumcision as part of the important initiation ceremony by which a child became an adult. Although the government had decided to use education as a means of speeding the death of this custom, the attacks by missions on the custom "...were taken as attacks not on the severity of the operation itself but on the whole initiation ceremony and so on the whole body of traditional Kikuyu custom."4I The controversy over female circumcision unified the Kikuyu. This conflict was to lead to the

40 Ibid., P. 156. p. 363 .

$4 I_{\text {Harlow }}$ and Chilver, History of East Africa, II, 
emeIgence of Arrican politicaj. crganizations directed against the Europeans. The indeperdent school movement was one of the most important and immediate outgrowths. 42 As a result of the circumision controversy two educational groups were formed: the Kikuyu Independent Schools Association (KISA) and the Ki Karinga Educational Association (KKEA). The KISA tried to work with the government to bring about changes in non-mission schools. This group was funded by the central government and local native councils. The KREA avoided any asscciation with the government. The KKEA was oriented to the Kikuyu tribal ideas and traditions: While a number of leaders of KKEA were leaders of KCA, KKEA became involved in KCA.43 In 1939, the renya Teacher Training College was founded at Githunguri in Kiambu. This college was to provide teachers for the independent schools. It later fell largely under the control of the KCA and Jomo Kenyatta. 44

There was also a break with mission churches with the development of African Independent Pentecostal Church associated with KISA and the African Orthodox Church associated with KKEA. These churches and various splinter sects acted as a sounding board for anti-European feeling. By 1947, there were a number of sects, one of which was the

$$
\begin{aligned}
& 42 \text { Ibid., pp. 364-65. } \\
& 43 \text { Ibid., p. } 366 . \\
& 44 \text { Ibid., pp. 367-70. }
\end{aligned}
$$


"dinl yo Jesu Kriste."45 According to D. H. Rawcliffe, anothex was the Mau Mau movement, but there is no real eviderce to support this. 45

By the end of the Second World War, certain changes were discernible in the form of Kenya society, marked by the decreasing importance of traditional social groupings-especially those based upon kinship--and the emergence of

.. Individualization on the one hand and of new occupational, religious, and political association on the other. The main consequence of the Second World War was certainly the immense widening of the experience of most of the men recruited. 47

Towlt the end of 1945 the representation of Africans in the Legislative Council became a burning issue. Eliud Mathu, a we1 1 -educated Kikuyu, was nominated as the first African member of the Legislative Council in 1944. This nomination led the first sustained effort of the Africans to create a "eongress organization" to cover the Africans of the whole colony. Eliud Mathu formed the Kenya African Study Union as orum of all shades of articulate African opinion. Its alms as originally declared were (a) "...to unite the African people towards an African union," and (b) "...to foster

$\dot{5}$ Ibid., p. 372 .

${ }^{46}$ D. HI. Rawcliffe, The Struggle for Kenya (London, Vietor Gollencz Ltd., 1954) pp. 30-35. PP. 385-86.

47 Harlow and Cnilver, History of East Africa, II, 
the social, economic, and political interests of the African." 48 This organization by 1945 was "...championing such long-standing African grievances as 'the abolition of the Kipande (registraticn certificate required of all Arrican adult males), the restoration of our lost lands, and more representation in the Legislative. "" The Kenya African Study Union was not seeking independence for the Kenya colony.49 On June 1, 1947, Jomo Kenyatta was installed as president of the Renya African Study Union which had in the meantime assumed the title of Kenya African Union (KAU). Between 1945 and 1953, KAU was engaged in a long and futile struggle to achieve political change by reform. In addition to the commanding issue of 1 and and to its demand that the report of the Kenya Land Commission be revised, KAU's policies were directed toward achieving equality with Europeans. Its influence upon the government, however, was negligible. British government support for the idea of equality in the Legislative Council made little difference. Because the Europeans wanted to retain their predominance, they rejected any idea of equal. representation in a Central Legislative Council. 50

48F. D. Corfield, Historical Survey of the origins and Growth of Mau Mau (London: H. M. Stationary Office, 1960), p. 49

49 Rosberg and Nottingham, "Mau Mau," p. 215. $50_{\text {Ibid., P. } 221 .}$ 
The post war era brought economic pressures, rural and urban unemployment, and overused land. Soil and cattle conservation became points of controversy. Some Europeans had permitted the kikuyu to cultivate and graze small plots on lands a.tierated by the Europeans. Throughout 1945, more rigorous administration of these squatter agreements in various sections of the Rift Valley Province, brought about a reduction of the number of stock and areas for cultivation allowed to Africans. This in turn forced many African squatters to leave European farms and return to the reserve. These "dispossessed" Kikuyu, coupled with those who had left the settlement scheme at oleaguruene, returning to the already overcrowded reserves were a potential source of trouble of which agitators were not slow to take advantage. 51

Many young African men who served in the British forces were exposed to new attitudes and ideas while abroad fighting against the Germans, Italians, and Japanese. They became trained in various skills, many of which were not marketable in Kenya on their return. Some of these unemployed became thugs and criminals; others became interested in politics as a means of achieving their goals. A number of returned servicemen became members of the "Forty Group" (Anake a 40) which hoped to bring about changes in the African situation. 52

51 Cortield, Mau Mau, p. 66.

$52^{2}$ osberg and Nottingham, "Mau Mau," p. 240. 
F. D. Corfield (a complier of the official Kenya government report on the Mau Mau) claimed that in February, 1947, Jomo kenyatta was reported as supervising an oath of secrecy binding on members of the proscribed KCA. The month before he assumed the presidency of the KAU, he assumed control of the Kenya Teacher Training College. Corfield quoted Kenyatta during this time "'Africans would obtain their freedom only through bloodshed." Corfield felt that with this "the stranglehold of KCA on KAU although not fully recognized was established." He also cited the fact that here were attempts to undermine the chief authority, e.g. by holding unathorized meetings to disrupt and halt government action on such programs as soil conservation in wich the women had been working. 53

At the end of 1947 , the District Commissioner of Fort Hall secretly informed the Director of Intelligence and Security:

There is a very strong rumor circulating that all the wrongs of the kikuyu will be simultaneously righted by the murder of all Europeans. This has come from two sources, but in neither case did the source say when "der tag" was going to be. 54

In late 1949, the Electors' Union published their "Kenya Plan", which African leaders interpreted as an authoritative restatement of European intentions to create a white-dominated

$$
\begin{aligned}
& { }^{53} \text { Corfield, Mau Mau, p. } 67 . \\
& 54 \text { Ibid., p. } 72 .
\end{aligned}
$$


British dominion in East Africa. The publication of the plan convinced them of the urgent need for far more effective political organization and above a11, unity, if their goals were to be achieved. If poittical action was to be effective in bringing about essential changes then some means had to be Found to overcome disunities within African society and to raise and sustain committment to specific political actions. 55 As a result, an oath was incorporated. The oath was used to provide a sense of unity among the Africans and to give bounds to the group. The person who took the oath made a total comiltment to the group. Each oath taker was to serve the interests of the group rather than self.56 Oathing is tzalitinnal in the Kikuyu society. Its implementation was to give strength and identity to the Kikuyu at a time when they felt they were threatened. The oath was utilized to achieve political unity and to develop organization through which to function. In addition, the oath was to develop a sense of nationalism.57 Though the economic plight and aspirations of the Kikuyu had long supplied the main drive behind African nationalism, the KAU leadership realized that the real. key to the future lay in

${ }^{55}$ Rosberg and Nottingham, "Mau Mau,", PP. 241-42. 56 Ibid., pp. $244-48$.

57 Ibid., Pp. 259-60. 
the political control of the country. By 1950, KAU had launched a campaign to gain substantial representation in the colony's Legislative Council, initially requesting twelve elected members as compared with the European settlers' eleven, and African appointees to the posts of Assistant Secretary and Deputy Chief Native Commisioner. The dramatic demands by ultra-militant urban groups in 1950 and 1951 for self-government "now" while representing a growing revolutionary force did not influence KAU's policy until 1952. Implicit in their expressed goal of a common electoral role for all races was the ultimate objective of an African self-governing state. 58

For some years discussions had been held concerning European, Asian, and African representation in the government. As this became an increasingly important issue in May, 1951 , James Grifiths, Secretary of State of the Colonies, visited Kenya. He declared that by 1952 representatives of the African, Asian, and European groups in consultation with a chafrman from outside the Legislative Council should consider constitutional changes. If they failed to come to any agreement on recommendations, Griffiths claimed that Great Britain would initiate the changes she felt best. Griffiths'recommendations were not the reforms needed. They were stop-gap masures. Neither the government of the colony nor of Britain

$$
58 \text { Ibia., pp. 225-26. }
$$


realized the impendirg crisis. By this time, the Africans realized that the government was really not concerned with the demand for political reform. The possibility of achieving political development through proportionate and direct representation of the Africans became increasingly remote. As a result those persons who advocated violence and direct confrontation increasingly gained support.59

By the time of the mass meeting in Nyeri on July 26 , 1952, the militants shoved their power. Although Kenyatta's leadership was in evidence, this meeting made it clear that he could not control those Africans who by that time were thoroughly convinced of the impossibility of achieving change Deaceiuly. Although the riklyu were linited behind the image of Kenyatta, he was not able to control all. The support for the militants' advocacy of violence was indicative of the extreme frustration felt by the African population. 60

The October 7, 1952, assassination of Senior Chief Waruhiu and increasing attacks on Europeans led the new governor, Sir Evelyn Baring, to declare a State of Emergency october 20,1952 . At that time the governor requested troops and military assistance from Great Britain.

$$
\begin{aligned}
& { }^{59} \text { Ibid., pp. } 229-33 . \\
& { }^{60} \text { Ibid., pp. 274-75. }
\end{aligned}
$$




\section{WHITE PERSONAL MEMOTRS}

In the period from May to October 1952, fifty-nine Africans loyal to the Kenya government including Senior Chief Waruhiu were murdered, allegediy by the Mau Mau. Waruhiu, a Christian, had been appointed by the government as its spokesman to the Kikuyu. His murder united all Europeans in demanding'government action. ${ }^{1}$ The first Europeans were not killed until after the declaration of a State of Emergency although, according to corfield, "...between the first of october and the declaration of a State of Emergency, the Mau Mau threat to Europeans was put into effect."2

From various officials, including provincial commissioners, district commissioners, and police officials, the government had received reports which gave evidence of the growing discontent of the Africans, especially the Kikuyu, and the development of KAU and of the Mau Mau. However, the government had done little which proved effective in combating the growth of the discontent of the Mau Mau. Although.

$$
\begin{aligned}
& { }^{1} \text { Ibid., p. } 276 . \\
& { }^{2} \text { Corfield, Mau Mau, p. } 159 .
\end{aligned}
$$


the Mau Mau had been declared a prohibited organization in September $1950,{ }^{3}$ the oath ceremonies mentioning Mau Mau which were first reported as having taken place in 1947 continued. 4 Numerous acts of violence including arson were reported and continued even after the declaration. It is possible that some of these were not connected with the Mau Mau but were manifestations of general social discontent.

It should be pointed out that the government had really done little to consider the grievances of the African population and to understand the African reaction and tactics in trying to achieve a more equal and active participation in the economic, political, and social life of the country. The goverment gave littie opportunity to Africans who might have offered suggestions and participated as moderates within the the established structure. Therefore, many Africans, even those who were moderates, felt that in order to achieve any progress for their people it was necessary to take some steps against the government. Tactics of civil disobedience on the part of some Africans were efforts to gain followers for their own interests, as well as to protest European and government policies and attitudes. 5

$$
\begin{aligned}
& { }^{3} \text { Ibid., p. } 314 . \\
& { }^{4} \text { Ibid., p. } 17 \text { and p. } 312 . \\
& { }^{5} \text { Ibid., p. } 119 .
\end{aligned}
$$


Initially, government files, personnel, and African leaders were rot acressible to those persons wishing to understand the Mau Mau uprising and its causes. Therefore, they had to rely on other sources. Among the first non-official publications were two books by the famed Kenya-born anthropologist, L. S. B. Leakey, whose parents were missionaries. During the decade of the $1950^{\prime}$ s, Leakey was the European most knowledgeable about the Kikuyu. He acquired krowledge of the Kikuyu language and customs while growing up with Kikuyu playmates. Although his primary study in Kenya has dealt with anthropological remains, he was interested in the problems of the country. For Leakey, the Mau Mau had personal significance. His cousin was kidnapped and buried alive, allegëdly by the Mau Mau. It is possible that the Mau Mau felt it recessary to get rid of Europeans who were close to Africans. These Europeans were a threat. However, some Kikuyu were not willing to join the Mau Mau forces to rid the country of the European control. The Europeans represented the European settler government which was under attack.

Leakey realized that almost all aspects of EuropeanAfrican relationships resulted in conflicts which were to eventually give rise to the Mau Mau movement. The areas of contact included medicine, education, economic structure, political structure, land, and religion. The repercussions were to be grat in the life of the Africans. As an anthropologist, 
Leakey was aware of the interrelacion between situations and the intricate interaction between peoples of different cultures. Leakey stressed the misunderstanding and change brought about by the presence of the settlers and the British administration in Kenya. He argued

...it is probably because the speed of progress has been too rapid that it has made a part of the population unbalanced in their outlook and this paved the way for movements like the Mau Mau, in the hands of an unscrupulous few. 6

Leakey was ore of the few Europeans who appreciated and understcod the position and importance of land in the life of the kikuyu and understood why the land issue was a major grievance. Land was a form of social security. Although ar African right work in the sity or a town, he would not make enough money to support his family there. His wife or wives and children would live on and cultivate the shamba (small plot of land) which might provide enough food for subsistence and possibly provide a cash crop. When he retired, this shamba would still have to provide food and shelter. If he worked on a European farm he would usually be allowed to cultivate a small plot to provide subsistence, but he would need his own land to return to when he retired.

Kikuyu transactions with tribes concerning land were accompanied with special ceremonies prior to the land purchase

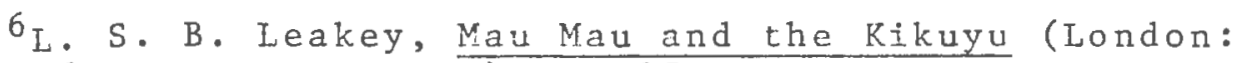
Methuen and Co., Ltd., 1952), P. 85 . 
and transfer of property rights. 7 According to Kikuyu tradition and law

land occupied and owned by other people cannot be acquired simply by conquest, for if this were done and the previous owner forcibly dispossessed, the Kikuyu fully believed that the spirits of the owners would make it impossible for the new occupants to carry out their agricultural activities with ary hope of success or with any hope of the blessing of Ngai. [Ngai is the Kikuyu god who had, according to tradition, given the Kikuyu rights to certain lands.] 8

During the nineteenth century the Kikuyu had expanded south especially into Kiambu, an area northeast of Nairobi. As a result of a decrease in population due to rinderpest, smallpox, plague, and drought which had ravaged them just before the arrival of the Europeans, the Kikuyu had withdrawn north temporarily. However, this grazing area in Kiambu was still held by the individuals and their families through the right of inheritance. This land was not held by the tribe on a communal basis. The British believed that the land was not used and did rot belong to anyone. 9 sheep and goats are very important in the social, religious, and economic life of the Kikuyu. Therefore, land was needed for grazing of sheep and goats. 10

With the derrease in natural disasters and the introduction of European medicines, the African population steadily

$$
\begin{aligned}
& { }^{7 \text { Ibid. }}, p \cdot 4 . \\
& { }^{8} \text { Ibid. }, p \cdot 2 . \\
& { }^{9} \text { Ibid. }, p \cdot 12 . \\
& 10^{\text {Ibid }}, p \cdot 16 .
\end{aligned}
$$


increased. As the population increased, Kikuyu families started to move back to the lands which they had temporarily vacated. Upon their return, they found Europeans living on and farming these lands. Some of these areas became known as part of the White Highlands. Although the settlers or the government had in some instances purchased land from the Kikuyu, these purchases were not transacted according to Kikuyu law and custom. Despite the fact that money was paid, there was no provision for a ceremony to placate the ancestral and other spirits as well as Ngai.

Therefore, the Kikuyu believel that these lands still belonged to them. However, Leakey mentioned that "...the British were wholely unaware that from the point of view of Kikuyu law these payments did not and could not ever rank as purchase of the land."Il All of the land purchased was private property. Although the amount was relatively sma11, its purchase displaced a sizeable number of Kikuyu. 12 The government failed to appreciate the fact that Kikuyu land ownership in the Kiambu area [fertile area to the northeast of Nairobi] was based on individual family holdings and was not based on tribal holdings. These holdings were well marked by the kikuyu. The government's failure to acknowledge this situation became a source of discontent. 13

${ }^{11}$ Ibid., p. 65.

12 Ibid., p. 66

13 Ibid., p. 69 
Some Kikuyu found it necessary to sell their lands to other Kikuyu who had become wealthy. This resulted in increased numbers of people being landiess. Many of the young men who did not own land and who could not afford to buy land, demanded that alienated lands be restored to the Kikuyu or that other lands be provided as compensation. 14

Numerous grievances concerning land were considered by the Carter Land Commission in 1934 and compensation was paid. The problem was complex for some of the land in auestion had been held privately and not by the tribe. The compensation was paid to the tribe and not to the individual owner, even in those cases where land was held individually and not tribally.

According to Leakey, in 1950 the Mau Mau "...started spreading the fantastic story that the raising of Naircbi to city status was to be accompanied by further 'thefts of Iand' from the Kikuyu by the British authorities." However, keeping in mind past events, one may not consider this Mau Mau story so fantastic. The Mau Mau adopted the cry "'get back the 1ard." The KCA had had land as one of its major issues since the ear1y $1920^{\prime} \mathrm{s}$. Leakey felt that the Kikuyu, in po11tical affairs, had not exhausted the possibilities of settling the question in a constitutionally prescribed manner. 15

\footnotetext{
14 Ibid., p. 69.

15 Ibid., p. 87 .
} 
In essence, the government and the Europeans prevented African utilization of the constitutional whannels. Africans were not provided instruction concerning the procedures of constitutional change devised by the Europeans.

The Africans were politically immature according to the British; but the only way one can mature is through experience and education. There were very few opportunities for Africans to learn the art and science of Western politics. It is possible that the European government did not want the Africans to learn. One must remember that the government representatives in the tribes were chosen by the government. It was very difficult to express ideas and problems through this limited line of communication. Even if the Africans had been familiar with this system and had participated in it, it is possible that their efforts would have been thwarted and prohibited.

The government allowed the Kikuyu to own land only within the reserves, the boundaries of which were established by the government. With the increase in population, the limitation of available land led to an increased density of population within the reserves. This condition contributed to the growth of Mau Mau. Leakey felt that it was necessary, especially for economic reasons, for some steps to be taken to ensure that the population did not continue to increase so. rapidly. Birth control was cssential.16

16 Ibid., p. 2.1 . 
The European economic structure and culture were to bring about orher changes in African 1ife. These changes, including the breakdown of marriage customs, contributed to the discontent and mental unrest which formed a basis for the Mau Mau movement. 17

one of the major areas of contention between the Europeans, especially missionaries, and the Africans was circumcision, especially female circumcision. Much of the information necessary in order for the adolescent to be prepared to accept his or her role and responsibilities as an adult was conveyed during the preparation prior to the circumcision and the actual rite itself. This rite functioned as one of tho educational and stabilizing elements of the society. Although Leakey did not support the use of this ritual (primarily because of its physical danger) he realized the value and the social elements it possessed. He contented

...that the failure to find an adequate substitute for the character-training and preparation for citizenship, which the age-old Kikuyu initiation rites used to give, is just one more underlying cause of the present and state of affairs in the Kikuyu tribe.18

By 1930, with the official elimination of circumcision rites and its education, Leakey felt that the education system established by the Europeans had not provided "... any real preparation for good citizenship and the responsibilities

$$
\begin{aligned}
& 17 \text { Ibid., p. } 16 . \\
& 18_{\text {IbId., p. }} 23 .
\end{aligned}
$$


for modern 1ife."19 Wichout this preparatior, many problems developed which might have been prevented if the Africans had received an education which would nave provided a basis for understanding the European culture and an opportunity to incorporate aspects of their traditional values. Without a set of values, particularly when one's society is undergoing transition, one will feel rootless and not know his responsibilities. When this situation develops, the unsettling effect on the society will be proportionate to the number of peopie who have not received a set of values and knowledge of the structure of their society through eâcation. The Kikuyu child traditionally had learned his responsibilities to his family and to society early. Through tribal education and experience, the child became well versed in the structure of the tribe.

The Kikuyu extended family relationship system, which provided stability within the family and the tribe, was misunderstood by the Europeans. An individual's family responsibilities extended beyond his immediate family. 20 Another element which united the tribe was the age-group system. The age-group to which an individual belonged was determined by the year in which he was circumcised. Usually the rite was

$$
\begin{aligned}
& 19 \text { Ibid., p. } 71 . \\
& 20 \text { Ibid., p. } 33 .
\end{aligned}
$$


not performed every year. Those initiated together were said to belong to the same age-group which recejved the name of some important contemporary event. People who belonged to the same age-group had ties and responsibilities to one another. The duties of the individual depended on the age-group to which he belonged. Later they would become elders, some of whom would compose the Council of Elders. With the prohibition of circumcision, which by 1930 included male as well as female circumcision, the age groups were not readily formed for the tribal members of the same age had not experienced suffering, socializing, and learning together. As a result, Leakey observed

...there is no longer any age-groun loyalty. The

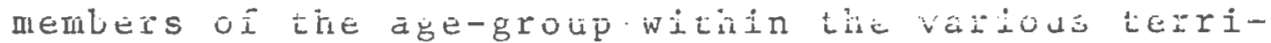
torial areas never meet regularly and therefore the fear of exclusion îrom age-group affairs has ceased to exert any power to control the action of the individua 1.21

Therefore, another form of sociological control of the individual was lost.

The Kikuyu tribe had no chief. Therefore, the implementation of the Lugard system of indirect rule was adjusted to meet this situation. There was no established direct line of control and communication which was available in other societies governed by a chief. In some. ways the kikuyu council of Elders appears to have been more democratic than 
gorerning structures in other tribes. The basic administrative body of the tribe was the council composed of senior elders whose leader or spokesman was known as Muthamaki. This term was often misinterpreted as chief by the Europeans. The council's authority was derived from subsidiary councils.22 The spokesman held no personal power. The Kikuyu system of control of the individual and the society was decentraiized. The Europeans did not appreciate its effectiveness. The colonial government appointed the spokesman of the senior council as "chief" if he served the government's interests. However, if the spokesman was not amenable to government control, another was appointed. Thus the Kikuyu were under control of a government system which was compietely alien to kikuyu practice and tradition. 23

Although the spokesman for the council of Elders was often designated as chief by the Eritish administration, Europeans were appointed to fill such positions as Provincial Commisioner and District Commissioner. It soon became apparent that it was impossible for these Europearis to perform all the functions delegated to them by the government: Educated Kikuyu clerks and headmen, therefore, acquired more responsibilities. However, many used their positions to their own advantage and were not concerned about their fellow

$$
\begin{aligned}
& 22 \text { Ibid., p. } 35 . \\
& 23 \text { Ibid., p. } 36 .
\end{aligned}
$$


tribal members. Many were djshonest. As a result, for all Kikuyu, these people gave the government a bad name. Although in many instances the government had good intentions, misinterpretation tinrough all the lines of control often produced distrust and discontent. 24

Like the governing Courcil of Elders and the family structure, religion had afforded conesion in this comparatively loosely-knit tribe. Religion in most societies functions as a controlling force and a stabilizing factor. Missionaries in many cases were among the first Europeans to settle and have direct contact with the Africans. The Europear values and culture, both material and spiritual, were part of the missionaries' baggage. Their conceptions of African life, as it was ard as it should be, did not always take into account what Africans already had and what they would experience in their contacts with other Europeans. This situation was further complicated by competition among the various missions for African converts. As a result, Africans saw that there was no complete agreement among Europeans concerning religion and that Europears did not adhere in practice to the Christian principles. Leakey pointed out that ...the breakdown of the old system and the substitution of other religious ideas has also played its part and in some cases a very large part, in the present Mau Mau situation. 25

24 Ibid., p. 63. 25 Ibid., p. 39. 
The Kikuyu religion has three basic piemises: a belief in an omipotent god; worship and placation of ancestral spirits; "...belief in certain spirits that are not in any way human nor yet linked with the concept of God."26

Religion was much a part of the Kikuyu life. ${ }^{27}$ Religion became a point of conflict. Hostility toward missionaries developed. The new religion acted as a disruptive force without the missionaries and other Europeans appreciating its effect. With the introduction of Christianity, especially throughout the mission schools, the cohesion of the Kikuyu tribe was threatened in two basic ways. Those Kikuyu who were Christian would not take part in traditional religious practices. The tribal religion required all males to take part. A religious ceremony was not valid without total participation. 28

As with all the other aspects of Kikuyu life which came into contact with European culture, one might say that Leakey felt those persons who had something either materially or spiritually to hold onto were not as apt to voluntarily become involved in Mau Mau. Leakey felt it was

\footnotetext{
${ }^{26}$ Ibid., PP. $39-43$.

27 Ibid., p. 44.

28 Ibid., p. 59.
} 
...of the utmost significance today that the leaders and also the followers of such movements of the Mau Mau are not drawn from those who are truly christian nor yet from those who have remained true to the old Kikuyu religion and who are horrified by the methods of Mau Mau and of its teaching. They are drawn from the thousands of sorcalled Christians, nominally, but only nominally atherents of one or another of the Christian missions, or from the many thousands of others who belong to the separatist kikuyu churches. 29

The latter had no spiritual traditior. Their concepts were a combination of tribal and Christian religion. One might infer from this that Leakey was more prepared to accept those Kikuyu who had truly converted to Christianity. At least he accepted those people who held to their religion and were not using it for their own ends.

In adition to the aspects of the kikuyu religion mentioned, 는 Kikug also believed in the porters of magicians and had a fear of magic powers. There were two types of magic--black and white. Genera11y, black magic designated negative and destructive powers, and white magic positive and creative powers. The tribal magician or medicine man held a very important position in the tribe for he practiced white magic to lift curses, to cure the ill, and to prophesy. The Kikuyu held complete faith in the medicine man's power. 30 Within the: tribe, the custom of oath taking had developed specifically to settle questions of individual guilt or innocence which the tribal court had not been able to settle.

$$
\begin{aligned}
& { }^{29} \text { Ibid., p. } 61 . \\
& 30 \text { Ibid., p. } 49 .
\end{aligned}
$$


By taking the ceth, the oath-taker pledged that he was speaking the truth. If he did not, then either he or his family would be struck with catastrophies. Leakey mertioned that

...fear of niagic powers was the foundation stone of all Kikuyu ceremories of oath-taling and in consequence the taking of a solemn oath was an act never lightly undertaken ard once sworr its effect upon the taker was very great. 31

The oath-taking ceremony was centered around an oath-stone, which had seven holes in it "...symbolizing the seven apertures of the human body and the unlucky number seven." The oath-stone was set upon a very special plant having seven branches together forming a platform upon which the stone could be set, and seven sticks of another were used as well. The ceremony rust take place in public in daylight and with as many witnesses as possible.

...each party was called upon to insert one of the seven sticks seven times in each of the seven apertures, while at the same time solemnly declaring that if the claim he had made before the court and which he had to repeat at the oath-ceremony was false he called upon the oath to kill him and his family. ...for the Kikuyu an oath-taking ceremony according to native law and custom was (a) one which could not be entered into lightly, (b) should be taken voluntarily and with the approval of the rest of the family. ...However, the Mau Mau violated more and more the rules governing oath-taking and so grew into something which was wholly contrary to established native law and custom. 32

31 Ibid., p. 51 .

32 Ibid., Pp. 53-55. 
The Mau Mau developed the oath in order to bind individuals to the organization. Leakey stated at first the oath was negative and not positive and required that the oath-taker ào nothing which would adversely affect Mau Mau. However, the oath-taker was required to give material aid if demanded. 33 The second oath demanded positive acticn. In this case, the oath-taker was required to actively support the Mau Mau. Support would include murdering any opponent of Mau Mau if deemed necessary. 34 If someone refused to take an oath, he would be killed.35 However, a strong fear of the "supernatural punishments" which would afflict those who failed to obey the oath managed to persuade most to obey. 36 With the advanced Mau Mau oath each person was made an outcast. It was impossible for ary person taking this oath to vecome assimilated into the rest of the kikuyu society again. This oath was to bind together very closely those who had taken it. It was necessary to transform the oath-takers "...mentally from human beings to something far beastlier than any animal in creation." 37

${ }^{3}{ }^{3}$ L. S. B. Leakey, Defeating Mau Mau (London: Methuen and Co., 1955), p. 81 .

$$
\begin{aligned}
& 34 \text { Ibid., p. } 82 . \\
& 35 \text { Ibid., p. } 83 . \\
& 36 \text { Ibid., p. } 84 . \\
& 37_{\text {Ibid., }} . \\
& \hline
\end{aligned}
$$


When an alien culture with all or some of its compoIents is slperimposed upon another, the immediate reaction may not be revolt. That often requires that the full effects of the contact permeate the whole society. While the members of the Kikuyu tribe soon after the turn of the century began to zealize the control the Europaan government was exercising, the effects oi this control had not been acknowledged by the whole tribe. Physical reaction or revolt does not usualiy develop when wo peoples first interact with one another. A people may revolt when they realize or believe that they no longer possess a culture and a way of 1 ife and when they have not been able to adapt and participate in a new culture. They feel that they are suspended without being able to move and to develop in any direction, for the old culture has been destroyed and they are not part of the imposed culture, except in isolated components. They have been given some of the rules but are not permitted to play. Leakey observed that this situation had developed to the extent that

...the breakdown of the old system of authority and the failure up till now of the new system to get fully into its stride and to have become really accepted by the masses, has certainly been a contributory factor in making the present outbreak of lawlessness--fermanted by Mau Mau--possible. 38

${ }^{38} \mathrm{~L}$. S. B. Leakey, Mau Mau and the Kikuyu, (London: Methuen and Co., Ltd., 1952), p. 38 . 
Defeating the Mau Mau, Leakey's second book concerning the Mau Mau, included an examination of materials which support his analysis of the purposes of Mau Mau, which he articulated to be (1) the recovery of iands allegedly stolen by the Europeans, (2) procurement of self government, (3) destruction of Christianity, (4) restoration of traditional custors, (5) elirination or subjugation of Europeans, (6) abrogation of soil conservation practices, and (7) development of secular education. 39 However, Leakey also contended that Mau Mau had become a religion. He examined the power and the purpose of this movement in becoming a religion. In examining some of the Kikuyu Christian hymns, Leakey pointed out that some lyrics were rewritter by the Mau Mau. Few Europeans realized the change and fewer knew the new verses. The hymo were used especially to educate illiterate Kikuyu about Mau Mau. This method was very satisfactory for the Kikuyu tunes could disseminate information and ideas without the knowledge of Europeans, especially government officials.

The aims of Mau Mau were combined in many of the hymns. Some verses of the hymns articulated desire for land; for self government; for the elimination of the Europeans and those blacks who had accepted the Europeans' ways as their own. "'As for you, you Europeans, know ye well that on the

${ }^{39} \mathrm{~L}$. S. B. Leakey, Defeating Mau Mau (London: Methuen and Co., Ltd., 1952), p. 21 . 
day when God comes to our aid you will be driven out." "40 Africans were encouraged to "'...rise up in arms so that our [African] lands may be returned to us [Africans]."141 In an effort to destroy Christianity, Mau Mau became a reijgion with kenyatta revered as a savior. The Kikuyu desire to renounce employment by Europeans and to obtain control of the government with the help of Kenyatta was expressed thus: "...never again will I be called "Boy." I will achieve self-government through Jomo Kenyatta.'1142 The following verse articuiated the Kikuyu desire to subjugate Europeans: "Oh, we shall be happy when the Europeans call us "Bwana." At present they call us "Boy" because they don't understand us. $" 143$

The relationship between the KAU and Mau Mau had been a point of concern. Leakey translated the first verse of one hymn: "I have planted myself firmly on the side of KAU," and then proceeded to show "...unmistakably that KAU is the same as Mau Mau," as was indicated in another verse which stated that "I am made strong by the oath, the oath of the children of Mumbi, I will never sell our land but remain on

40 Ibid., pp. 59-70.

$41_{\text {Ibid. }}$, p. 59.

42 Ibid., p. 69.

43 Ibid., PP. $70-71$. 
it for ever." 144 Leakey pointed out in a footnote that "the Mau Mau oath is regularly called 'the oath of the children of Mumbi,' and here it is Iinked with KAU in terms of complete unambiguity." 45 However, since Leakey did not provide the entire set of verses or ever the entire verse, it is possible that the quote was taken out of context.

rith limited material resources, e.g., arms and ammunition, the Mau Mau were forced into the position of adopting guerrilla tactics in order to rid the country of Europeans. Their objective was to make "...the position of the Europeans so uncomfortable and his [sic] economic position so precarious that the majority of white people would voluntarily pack up and go." This was to be done through the use of "harrying tactics and destruction $4 \bar{\sigma}^{\circ}$ When examining the Mau Mau, one notices that allegedly a large percentage of the members rere Kikuyu. Leakey offered several reasons why the Kikuyu dominated Mau Mau. The Ǩikuyu had more genuine grievances which could be magnified and exaggerated and used to work up feeling against Europeans.

The real leaders of the movement were kikuyu individuals with very considerable personality and qualities of leadership. The impact of these qualities naturally had a much greater effect upon their own people than upon members of other tribes. 47

$$
\begin{aligned}
& { }^{44} \text { Ibid., p. } 74 . \\
& 45 \text { Ibid., pp. } 74-75 . \\
& 45 \text { Ibid., p. } 100 . \\
& 47 \text { Ibid., p. } 104 .
\end{aligned}
$$


Leakey opined that while other tribes believed a movement against the Europeans would not be successil, the kikuyu believed that it could be. Leakey felt that had the Mau Mau movement not been so exposed as early as the declaration of the State of Emergency (1952) it would have"...spread to other tribes and other areas might have been a very real threat. $" 48$

Leakey viewed the Mau Mau uprising not just as the result of the desires of its leaders. The problems and misunderstandings which developed from the European and African contacts produced situations which were ripe for revolt. The government did little which was effective in trying to solve these problems. Problems had developed not only as a result of the European and African contacts but also as a result of the country's trying to find its role in the ever changing world.

Leakey was not concerned with naming many people responsible. His primary concerns were the Kikuyu and other African societies and their relationships with the European society. Although he did not approve of the violent tactics of the Mau Mau, he did not really offer any alternative solution. Leakey did feel that the problems should have been dealt with. The Africans should have used constitutionally established cinannels. Leakey suggested that government policy

$$
48 \text { Ibid., p. } 108
$$


be altered in. order to eliminate situations which led to the Mau Mau uprising. An educational system and curricula should be developed to prepare individuals for adult 1 ife and its responsibilities. Urban centers shouid provide Africans adequate job opportunities and services so that they would no longer need to be, at least partially, dependent on the reserves. Agricultural improvements should be initiated. Alternative arrangements for squatters should be made. The color bar should be eliminated. Communication between various elements of the population should be developed.49 These suggestions were seconded by Dr. J. C. Carothers in his pamphlet, The Psychology of Mau Mau, published in 1954. In addition, Carothers introduced the concept of "villagization" which he felt was needed "...to counteract their [the Africans] personal insecurity and give them a chance to develop new allegiances, to build up social services, and to increase employment opportunities." 50

In these proposed policies, one can see what some of the problems and situations were which gave rise to the development of the Mau Mau. If these problems had been solved or at least effectively acted upon during the 1940's, possibly violence would not have been adopted.

\footnotetext{
${ }^{49}$ Ibid., pp. 134-52.
}

$50 \mathrm{~J}$. C. Carothers, The Psychology of Mau Mau (Nairobi Government Printing office, 1954), p. 33. 
Dr. Carothers, a European psychiatrist, made observations in Kenya prior to and during the State of Emergency, as he was employed by various ageneies in Kenya. He observed that the kikuyu "...had particularly little sense of personal security for some years before the European's coming." This was a consequence of external factors, e.g., Masai raids, and internal factors, e.g., lack of centralized authority, 51

Talking about Africans generally, Carothers stated "...it has become only too clear that when European influence impinges on the African, his whole cultural machinery is apt to collapse quite quickly." He offered two major reservations. First, that the agricultural cultures fall apart more readily than pastoral or autocratic cultures. Although European education and European missions had been influential in Africa, Carothers believed that there was another explanation. The indigenous African's approach to life was mainly governed by the question of power. 52

Wherever the arrival of the alien was crowned with success and that alien was able to maintain himself in a superior fashion, the local culture was doomed precisely in the degree of his success and the extension of his influence. It is the material success of the immigrant which is first recognized and which sounds the death-. knell of the earlier culture.53

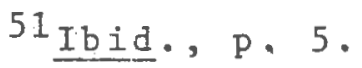

52 Ibid., p. 6.

53 IbId., P. 7 . 
Carothers felt that only a small percentage has been able to adjust to the new culcure, and tint many of the others were in a transitional state.54 The African's lack of personal security which had resulted from this situation did not allow him to realize that he might be the cause of problems. In addition, the African no longer had confidence in traditional customs and rituals. The African identified the European as the cause of problems. Traditionalys there had been an explanation of al1 events. 55

Carothers cited a number of factors which had worked on the Kikuyu more than other tribes. The Kikuyu had possessed a greater sense of individuaism. However, they increasingly had felt personal insecurity. Governmental authority was traditionally decentralized. The Kikuyu religious beliefs of a positive nature were not strong. The tribe had experienced longer and closer contact with alien cultuxes and alien "power". The kikuyu had tried to get this "power" through education. Education had led to great diversity within the tribe. There was extreme diversity in advancement within the Kikuyu society especial1y between men and women. Even with education many found that they were not allowed to participate actively. Education had given the educated "tremendous power for good or evil". The Kikuyu

54 Ibid., p. 7 .

55 Ibid., p. 8. 
conceived of education as a means of attaining power and wealth. 56

Many conflicts developed not only between Europeans and Africans but also within tribes and within individuals. For example, traditionally a kikuyu man's beliefs and behavior were molded by his mother. However, as a child matured in the twentieth century and was exposed to European culture, he realized that he no longer knew the extent of his power or the extent of his responsibilities. The rules which he originally learned could no longer be utilized. Carothers felt that the kikuyu had tried to deal with this situation in several ways.

Some Kikuyu had triad to return to the life style which existed before the arrival of the Europeans. Others had tried to make a place in the new culture. Still others took advantage of an unsettling situation for selfish reasons to gain either political power or wealth. The latter persons formed a basis from which Mau Mau developed.57 Mau Mau was the result of

...an anxious conflictual situation in people, who, from contact with the alien culture had lost the supportive and constraining influences of their own culture, yet had not lost their "magic" modes of thinking. It arose from the exploitation of this situation by relatively sophisticated egotists. 58 .

56 Ibid.: p. 8.

57 Ibid., pp. 9-11.

$5^{8}$ Ibid., P. 15 . 
As his monograph was primarily a psychological study of Mau Mau, Carothers was concerned with psychological analysis. He offered the following additional ideas concerning the Mau Mau. Africans seldom accepted responsibility for misfortunes. Misfortunes were caused by "'evil wills".After their arrival, the Europeans were considered to be the cause of all evil. Some Africans who had come to power, not Lhrough traditional channels, felt they were powerful enough to force the Europeans to leave and to take control themselves. 59

The Kikuyu did not see that there would ever be a chance for them to have an equal vote or to participate fully in the society which the Europeans had developed. As a result, frustrations increased. Thus we see again the froblem that, although many of the traditional aspects had been changed or destroyed by the introduction of an alien culture, people had not been allowed to fully adopt the new culture.

Carothers opined that it is easier to implement and to understand an autocratic government than a democratic one, ...for the application of democratic principles is especially difficult where societies are not relatively homogeneous in their level of sophistication for life in that society. This difficulty is apt to lead to an apparent inconsistency between theory and practice which, in its turn, must often lead to a sense of injustice in the others, 60

$$
\begin{aligned}
& 59 \text { Ibid., pp. 12-13. } \\
& 60 \text { Ibid., p. } 34 .
\end{aligned}
$$


The first three oaths drawn up by the Mau Mau were intended to develop a sense of tribal and national unity, according to Carothers. The foirth oath was intended to "...dedicate ard bind these people [the Kikuyu] to the purposes and fortunes of their new leader and his group, and ensure they have no other fucure."61

Let us now examine the Mau Mau from another perspective. The men who fought the Mau Mau included Africans, especially Kikuyu, some of whom were in the Home Guard;

Asians; Kenya settlers tho were in the Kenya Police or armed forces; British troops requested to arrive concurrently with the declaration of the State of Emergency; and several mercenaries. Several of these men wrote about their experierces and their ideas about the Mau Mau.

Ian Henderson, a Kenyan, who was a member of the Kenya Security Forces, was involved very deeply in the development and utilization of the pseudo-gang tactic. In 1956, this tactic was used to capture Dedan Kimathi; one of the Mau Mau generais idolized by his men.62 According to Henderson, Kimathi was "..the root of a 11 evil in the jungle."63 The Mau Mau forces in the forests were directed by men designated by the title general. The generals operated quite independently, although there was some organization among the forces

61 Ibid., PP. 16-17.

${ }^{62}$ Ian Henderson. With Philip Goodhart, The Hunt for Kimalhi (London, Pan Books, Ltd., 1962), p. 26.

63 Itid., p. 53 
brought about through their council meetings.

Henderson argued that the

...Mau Mau movement...was a blend of ancient and modern.

It owed much to the spirit of Arrican nationalism and the primitive trade union agitation which was growing in the towns. It owed more to witcheraft and the fear of witchcraft which flourished rost strongly in the reserve. Some Mau Mau leaders wanted to destroy the white marl; others wanted to uprot. every vestige of European civilization. Both these elements were combined in the loosely knit movement, but as time went on the more sophisticated agitators were replaced by the men who called for the rejection of all western ways. 64

Peter Drumond, born and bred in Kenya, was a police officer. Some of his observations and opinions have been recorded in Bwana Drum by Dennis Holman, who often interjected his own ideas. He felt that the Mau Mau revolt was partially a result of the devolopment of African rationalism which "... came from deep inside the smouldering volcano of their spiritual and economic needs." Had Kenyatta not been arrested or had he escaped and "...had he remained in control, kenya would have been spared the blood bath that was to follow" his arrest. 65

Drummond did not believe the main Kikuyu allegation that their lands had been stolen was based on historical fact. In a footnote, Drummond expressed his belief that for the smal1 amount of land (not in excess of 110 square miles)

\section{Ibid., p. 13}

65 Dennis HoIman, Bwana Drum (New York: W. W. Norton and Co., Inc., 1965), p.p.13-14. 
which had been alienated full restitution had been made. The lands in question,

...the White Highlands, were not seized as the Kikuyu agitators tried to claim, but settled as the result of a decision by the government who were concerned at the time with the economic development of vast areas of empty land, a development which was quite beyond the capabilities of the indigenous population.66

The European settlers felt that the land rightfully belonged to them. According to Drumond, the declared purpose of Mau Mau was to take possession of the alienated lands by killing the Europeans or by forcing them to leave the country. He mentioned that while many of the Mau Mau "...were not fighting for money or power but for Kikuyuland," and were "...the militant wing of a political movement," others wese "...a thig elenent...masqueradirg as Mau Mau gangs." 67 Henderson questioned the idea that Mau Mau was anti-white, for many more Africans whites were killed by Mau Mau, He felt that the Mau Mau did not have an organized pattern for revolt and had not articulated their aims even after the arrests following the declaration of the state of Emergency. 68 However, he said that after the formation of guerrilla forces in the mountain forests, Kimathi in his

${ }^{66}$ Ibid, , pp . 12-13.

67 Ibid., pp. 146.

${ }^{68}$ Henderson with Goodhart, The Hunt for Kimathi, PP, $14-15$. 
"Mein Kampi" had written how "...they wolid take over the European farms; how they would kill all those--black, white, or brown-who stood against them." 69

Henderson stressed the terror and the horror of the Mau Mau by choosing to use the following descriptions: "...they [the Mau Mau] were fanatics who had enjoyed killing children and slitting open the stonachs of pregnant women. They were savages, vicious, unpredictable as a rabid dog." 70 This behavior developed as a result of the perversion of traditional oaths by the Mau Mau leaders. These oaths forced people to promise

...to kill, to cut and burn. The taking of the oaths would be solemnified with bestial ceremonies, which included muching human brains and intercoursa with

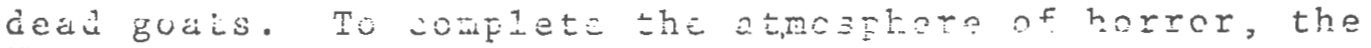
"oathing chapels" would be decorated with intestines and gouged goats' eyes.71

Holman quoted Drummond: "We were up against something more brutal and savage than the world has ever known, we had to destroy it by every means." 72

However, according to Drummond, there was no satisfactory explanation of the development of these horrors in the basically kikuyu movement for the kikuyu were a religious and human people. The horrors in the oathing ceremony were

$$
\begin{aligned}
& 69 \text { Ibid., p. } 23 . \\
& 70_{\text {IbId. }}, \mathrm{p} \cdot 142 . \\
& 71_{\text {Ibid. }}, \mathrm{p} \cdot 14 . \\
& 72_{\text {Holman, Brana Drum, p. } 66 .}
\end{aligned}
$$


not fundamentally kikuyu in character, they did not arise spontaneously out of the stresses attendant to the Kikuyu society in transition. 73

The oathing ceremony was to bind the people to the Mau Mau and to destroy their "sense of security and wellbeing". This sense of security was based on the belief that by their obeying tribal law and customs everything would be alright.74 Some unwilling initiates informed the police about the oathing ceremonies and Mau Mau activities. As a result, in 1950, the Mau Mau was declared an illegal society. The Mau Mau leaders then decided that it was necessary to oathe the whole Kikuyu tribe in order to have a united front. If a person refused to be oathed; even after being beaten he was murdered in front of initiates. 75

During the Emergency, while traveling through Kenya, an American, William Baldwin, became involved in fighting the Mau Mau as a member of the Kenya Police. Baldwin, following his service in the second World War, had been traveling around the world working when necessary. He took a position with the Kenya Police not only because he needed money but also because he was sympathetic to their cause. He felt

$$
\begin{aligned}
& 73 \text { Ibid., p. } 22 . \\
& 74 \text { Ibid., p. } 23 . \\
& 75 \text { Ibid., Pp. 12-13. }
\end{aligned}
$$


that the Mau Mau should not be considered to be "civilized persons".76 William Baldwin has written an account of his experiences and his ideas in Mau Mau Manhunt.

Baldwin believed that the basic problem which led to the Mau Mau movement was that "...too many people have tried to push the African ahead too fast and too far." The educated Africans' level of expectation were far above their abilities. These Africans should have utilized their knowledge to assist the uneducated. Instead these edrcated Africans were responsible for instigating the uneducated to participate in the Mau Mau revolt. 77

One of the lies that Baldwin felt was perpetrated by tho Africans was that the Europeans had stolen large areas of land from the Kikuyu. Baldwin claimed that three quarters of the 12,000 square miles of the land alienated by the Euro-. peans had not been utilized or occupied except by the Masai for cattle grazing. The other quarter was not inhabited. To a small area of this land the Kikuyu later laid claim. These claims were fully compensated by the government. 78

To prevent government and European knowledge of the existence of the Mau Mau, its leaders felt that it was

76.iliam W. Baldwin, Mau Mau Manhunt (New York: E. P. Dutton, and Co., Inc., 1957), P. 179 .

77 Ibid., p. 45 .

78 Ibid., p. 55. 
necessary to have all kikuyu people take an oath. 79 originally the oath was to develop a united political awareness. "...Failing this, the oath was intended to have such power over people through psychological fear that they would remain passive and not oppose the Mau Mau in any way."80 The new oath developed especially after the declaration of the State of Energency involved many types of depravity. Baldwin questioned why the government did not take action earlier to stop the growth of Mau Mau, although there had been reports of violence including rurder, oath-taking, and secret societies even 1n 1947. There had been much discussion as to the relationship of the KAU and Mau Mau. Baldwin opined that "...there is $1 i+t l e$ doubt that the KAU and Mau Mau while perhaps not synonymous, were very closely linked." 81

Baldwin described several situations, e.g., the circumcision controversy, which he felt were taken advantage of for political purposes. 82 The separatist churches and schools accepted no government funds and became increasingly antiwhite in their teaching. The children no longer received instruction in obeying the white man's law. They were instructed that the white man was an oppressor and a land thief. As

$$
\begin{aligned}
& { }^{79} \text { Ibid., pp } 57-58 . \\
& { }^{80} \text { Ibid., p. } 87 . \\
& 81_{\text {Ibid. }}, \text { p. } 58 . \\
& 82_{\text {Ibid. }}, \text { Pp. } 110-11 .
\end{aligned}
$$


a. result, by 1950 , the kikuyu had been taught to hate Europeans. The kikuyu were taught many lies and half-truths about their past. "In such fertile soil the bitter seeds of Mau Mau grew fast."83

Mau Mau ras presented as a religion. Propaganda was spread through the medium of Christian hymn tunes. This Mau Mau religion expressed faith in God and the Mau Mau leaders. Jomo Kenyatta was depicted as a savior or Jesus Christ. By disguising Mau Mau as a religion, initiates were able to convince themselves of the iighteousness of the cause and to believe that all activities were sanctioned by God. 84

$$
\begin{aligned}
& 83 \text { IUid, pp. 111-i2. } \\
& 84 \text { Ibid., p. 114. }
\end{aligned}
$$




\section{BLACK PERSONAL MEMOIRS}

St. Cla1r Drake in his introduction to R. Mugo Gatheru's autobiography, Child of Two Worlds, mentioned some American reactions to Mau Mau and to black Kenyans. Gatheru, a Kikuyu, had been studying at Lincoln University in the fal1 of 1952 when he was informed that his visa was to be revoked without explanation; however,

...the reason seemed obvious. Senator [Joseph] McCarthy was leading the lunatic fringe of American politics in a widely publicized witch hunt for communists who were known to foster revolution in colonial countries. Renya was seething with the Mau Mau disturbance which must, therefore, have been Communist-inspired; all Africans in kenya, or so it seemed to the McCarthyites, supported Mau Mau and were all ardent Communists; it was, therefore, "logical" that Mugo too was a Communist, a dangerous canker in the wholesome apple of American democracy. 1

Although Gatheru was not involved in Mau Mau, he made some observations concerning this period of his country's history. Gatheri believed that the basic problem was bound up with "...the lesson...for all to learn; all peoples have their dignity for which they will eventually resort to violence."2 He did not accept the idea that "...they organized

$1_{R}$. Mugo Gatheru, Child of Two Worlds: A Kikuyu's Stary (Garden City, New York: Doubleday and Co., Inc., 1965), PP. 13-14.

2 Ibid., p. 176 . 
Mau Mau in 1952 in an attempt to drive the Europeans from Kenya and consequently establish the Kikuyu dictatorship over the rest of the Kenya tribes, followed by a return to barbarism and darkness." 3

The British Government was an additional factor in the relationship between the Kenya settlers and the African population. Although occasionally attempts were made by the British Government to improve the African situation, its policies were eventually molded in the interests of the Kenya settlers and not of the African population.

An important aspect contributing to the loss of African dignity was the question of land alieration," "..real bitterress has been reserved for those who took our land from us."4 Following World War I, KCA had been established because the British soldiers received Kikuyu lands in payment for services in the war. 5 In 1923, the British Government's Devonshire Report stated "...that the rights of the Africans must be respected as the land was ours [The Africans]." The British Government unsuccessfully tried to have this policy implemented. However, the settlers threatened to revolt and set up an independent stace. As a result, the Devonshire policy was not incorporated or enforced. In 1934

$$
\begin{aligned}
& { }^{3} \text { Ibid., p. } 113 . \\
& { }^{4} \text { Ibid., p. } 114 . \\
& { }^{5} \text { Ibid., p. } 107 .
\end{aligned}
$$


"...about 17,000 square miles of the best land in Kenya was declared oper to white settlers on 1 y. "6 This land was added to those lands wich were already designated as White Highlands. This white settler policy of expropriating lands for their own use may be traced back to 1903.

The limitation of African participation in government was another source of irritation and frustration for the African. The following are several points which Gatheru raised. In 1947, White Paper 191 proposed that each of the three major racial groups--Africans, Asians, and Europeans-should have the same number of representatives in an East African Central Assembly. This would have provided for some more African and Asian representation in the legislature, but would have hardly provided representation proportionate to the population. At that time in Kenya there were 30,000 Europeans, 100,000 Indians, and 5,500,000 Africans. As a result of white settler protest even this concept of representation was dropped. Another which accepted "the principle of majority representation for the whites" was adopted. 7 One should remember that it was. not until 1944 that there was an African representatitive in the government. Even that representative, Mathu, was appointed by the government and not elected by the population.

$$
\begin{aligned}
& { }^{6} \text { Ibid., p. } 114 . \\
& 7_{\text {Ibid. }}, \text { p. } 89 .
\end{aligned}
$$


Another Instance of affont to the African dignity and self-respect this "child of two worlds" c1ted was the kipande system which was not abolished unt11 1950. The kipande was a registration card required for all adult Afr1can males: This oystem, begun after the First World War, constantly humiliated the African. 8 This was one grievance among the many which had developed as a result of the Europeong" tempts to keep their position of superiority.9

Kenyatta's role in trying to find an effective way to improve the Africans' situation was described in the following way by Gatheru. Kenyatta

... began to see the Kenya problem not just in terms of petitioning the British Government to rectify past injustices with regard to the land. He saw the problem as one of teaching Africans how to get enough political power to control their own affairs in Kenya...to the young people of Kenya in $1946^{\circ}$ he was an African Messiah who would now lead them towards self-government just as Azikwe In Nigeria and Nkrumah in the Gold Coast were doing: 10

Howevers he did not fndlcate how this political power could Be tratned.

Before leaving Renya to acquire an education, Gatheru

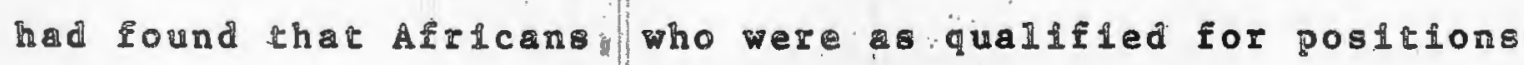

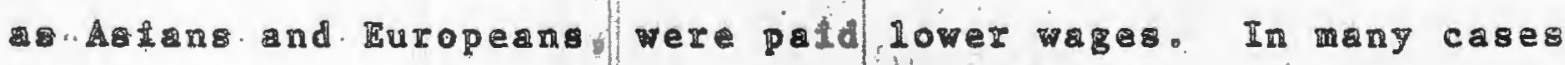

\footnotetext{
Ib1d. P. 91.

TDid:D Pa97,

10 Ibid, P, 108,
} 
Africans who were as well qualified for positions as Asians and Europeans were refused employment only on the basis of color. 11

Gatheru saw these grievances as being among the causes for the outbreak of hostilities. Perhaps one may assume that the Africans had reached a breaking point in a situation in which they were in reality less whan third class citizens in their own country. Gatheru's own experience of being refused permission from the kenya government to go to the United States to study was an example of the situation. Possibly this refusal (perhaps originating from the CID) had been based on the fact that Gatheru had been an editor for the KAU English-Swahili newspaper, The African Voice.

The position concerning Mau Mau of Tom Mboya has never been clearly defined, At the time of his assassination, Mboya, a Luo, was the Minister for Economic Planning and Development in the independent Kenya government. During the Emergency, he was involved with the organization and development of KLGWU. He was one of the first kenyans to have his observations about Mau Mau printed.

Mboya believed that Mau Mau developed as a result of the interaction of the "...weakness of the British Government, and its failure to check the increasing political dominance

1.1 Ibid., p. 79. 
cf the settlers" which brought about "...the creation of a social structure in whici the white settler established himself in a superior position, with the Asian providing the middle-class and the African the lowest social and economic class."12 In addition, Mau Mau grew from African grievances about political, economic, and social developments brought about by the Europeans' desire to retain their dominant position. 13 While al1 Africans wanted to be rid of European control, Mboya did not imply that there was a desire to be rid of Europeans. Basically he believed that it was necessary to bring about a permanent solution through the political sphere. 14 The Europeans feared proportional representation. They believed that proportional representation would result il African domination. The situation was complicated because many Europeans thought they knew better than the Africans what the Africans needed. In addition, the Europeans were afraid of losing their dominant positions. 15

Mboya felt that because the government had really restricted the efforts of Africans to change social, economic, and political conditions through the established constitutional channels and because

12 Tom Mboya, The Kenya Question: An African Answer (London: Fabian Colonial Bureau, 1956) p. 13.

$$
\begin{aligned}
& 13 \text { Ibid., p. } 13 . \\
& 14 \text { Ibid., p. } 17 . \\
& 15 \text { Ibid., p. } 35 .
\end{aligned}
$$


...African politics and politicians failed to receive the recognition which is essential for the development of "responsible" politics in any country, the blame for their extremism is equaliy shared by the government and the European community...the attitude has been to play down the position of the popular African leaders and to try to build up government-appointed chiefs and some other African who is prepared to become a yes man. This was comparatively easy in the absence of elected African members of the Legislative Council. But real African leaders can only be those who are accepted as such by the Africans themselves. 16

Although the government allowed African political organizations, it limited them to the district level and to district interests. This meant that they did not allow the development of any national African political organization. However, in order to deal effectively with the problems, Mboya felt that it was imperative for the government to allow the development of national poiticici urganizations and of African political leaders.17 Mboya dwelt on the idea that racial, political, economic, and social attitudes on the part of the European settler, the Kenya government, and the British government were responsible for the growth of Mau Mau.18 Only by expressing and discussing political views could some effective agreement have been worked out between the Africans, the government, and the settlers.

In Freedom and After Mboya said that since the beginning of the twentieth century the policy had been to develop Kenya to the advantage of the Europeans. Mboya quoted Charles

$$
\begin{aligned}
& 16 \text { Ibid., p. } 35 . \\
& 17 \text { Ibid., p. } 36 . \\
& 18 \text { Ibid., pp, } 28-32 .
\end{aligned}
$$


Eliot, British. Commissioner for the East African Protectorate writing in 1905 in East African Protectorate:

"In other words the interior of the Erotectorate, is a White Man's country. This being so, I think it is mere hypocrisy not to adnit that whice interests must be paramount, and that the main object of our policy and legislature should be to found a White Colony."19

The Europeans had preempted a sizeable proportion of the available land. Of the areas of kenya which had an annual rainfall in excess of twenty inches, more than twenty five percent was reserved for Europeans who represented one percent of the total population. 20

The Africans had not desired to use violence in trying to rectify their situation. But it became more and more evidenc that they would no: be able to ascomplish anything through constitutionally established channels. Peaceful tactics of civil disobedience were attempted. Their position became more complex when it appeared that the Europeans provoked the Africans to such an extent that the Africans could only react violently. These same Europeans had armed themselves. They were determined to use force against "a positive non-violent nationalist movement." 21 Mboya felt that although one might use non-violent methods to achieve one's rights, that it was "...always with the understanding that it could lead to vio1ence." 22

1963), p. 47 .

(London: Andre Deutsch, 20 Ibid., pp. 47-48.

21 Ibid, , p. 52 .

22 Ibid., p. 52 . 
Although Mboya realized that Mau Mau was violent, he also pointed out that the Security Forces met that violence with far graater violence, allegedly being paid according to how many Mau Mau they killed. Violence on the part of the Mau Mau did not develop without provocation.

In the cases of Algeria, Kenya, and Angola the Erustration which precipitated violence were clearly there, and the colonial powers of France, and Britain can not escape responsibility for having precipitated this violence... the question, then is... whether nationalism can be expected to remain silent when provoked to the extent it had been in these countries and when there are no constitutional channels through which nationalism can achieve its objectives. 23

Mboya further contended,

,. if one can draw a general rule, it is that in any colony where there has been considerable white settlement, violence ins beccme inevitable, although it was not the original policy of the nationalist party...the reason is that, where there has been white settlement, there has been resistance to constitutional change and this has created more obstacles to nationalism. 24

Mboya did not accept the idea "...that Mau Mau was the result of any revolt by the Africans against civilization or Christianity."25 He mentioned that

a.many tomes during the Emergency we said categorically that Mau Mau was the child of economic and social problems which had accumulated over the years and which had not found any solution through constitutional channels. They were nearly all problems of discrimination against Africans in different forms; discrimination in employment

$$
\begin{aligned}
& 23 \text { Ibid., pp. 49-50. } \\
& 24 \text { Ibid., pp. 50-51. } \\
& 25 \text { Ibid., p. 49. }
\end{aligned}
$$


and in salaries ( $I$ inad myseif been paid only one-fifth of the salary of a European doing the same job); refusal by Government to let Africans grow cash crops like coffee, tea, sisal, and pyrethrum...discrimination in post offices, hotels, and restaurants supported by a government which had made liquor laws laying down as an offense the selling or serving to an African of European liquor; discrimination by Governmert in giving aid to schools and hospitals established on a racial basis; the absence of African representation in the Legisiature or of any voice at all in the Government; the indirect rule of the African people chrough chiefs and administrative officers who did not reflect any $10 c a 1$ African opinion. All these irritations went together to create frustrations which accumulated over the years. 26

Land alienation was a most important source of frustration for the Africans. Most of the land alienated was in Central Province and the Rift Valley. 27 The Kikuyu were primarily settled in these areas. Most of the Mau Mau activities were in these areas. By the 1940's the question of land became very emotional. The Africans contended that the Europeans were wrong in assuming the land alienated was uninhabited. Although the lands were not actively used the lands in question were owned by a tribe or an individual. At the beginning of the century, some lands claimed by the whites were not heing actively utilized by the Africans because of a decrease in population due to natural disasters. 28

According to Mboya, Kenyatta was not responsible for the Mau Mau. The verdict at the trial in 1953 was not correct. Mboya expressed the belief that the trial was not fair.

$$
\begin{aligned}
& 26 \text { Ibid., pp. 44-46. } \\
& 27 \text { Ibid., p. } 47 . \\
& 28 \text { Ibid., pp. } 48-49 .
\end{aligned}
$$


The judge was biased. He was deiegated speciai powers in Kenyatta's trial. Only seiected witnesses were allowed to

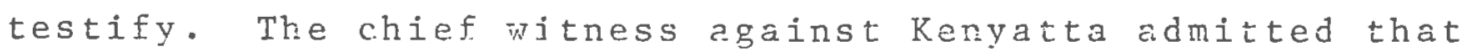
he did not testify truthfully about Kenyatta; possibly other witnesses perjured themselves. The chief witnass admitted also that he had accepted morey from the Kenya government for his testimony. 29

Jomo Kenyatta's involvement in Mau Mau and his responsibility for its development have been discussed by various writers. In very few instances have his views been noted. While in England, Jomo Kenyatta received a diploma in anthropology at the London School of Economics. As part of the course taught by the famed anthropologist, B. Malinowski, he wrote several articles about his tribe, the kikuyu, which were later published as a book titled Facing Mount kenya in 1938. Facing Mount Kenya was among the first works written about Africa by an African. Although it predates the Emergency, Kenyatta did not Iimit his observations entirely to an anthropological study. It is not an impersonal study, and it is not apolitical. He provided concise explanations and background to the customs and traditions of the tribe in addition to articulating the effect that the European settlement had had on his people.

$$
29 \text { I I I }
$$


Mogo wa Kebiro, a famous Kikuyu medicine man of the last century, through a dream foretold the coming of the white strangers with guns and later the building of the railroad. He warned his people that those strangers, empire builders, wanted to take land and everything else from the Kikuyu. The naturally hospitable Kikuyu, fooled by the Europeans, believed that the Europeans meant no harm. The Furopeans were granted

...a temporary right of occupation on the 1and...[and] cultivation or building rights. The Europeans were treated in this way in the belief that one day they would get tired of wandering and finally return to their own country. 30

The kikuyu soon realized that the Europears plarned to control the lands and Africans by force if necessary. 31 Eventually, when the railway from Mombasa to Lake Victoria was completed, Europeans

a. . began to claim the absolute right to rule the country and to have the ownership of lands under the title of "Crown Lands," where the Kikuyu, who are the original owners, now live as "tenant at will of the crown." The Kikuyu lost most of their lands through their magnanimity, for the kikuyu country was never wholly conquered by force or arms, but the people were put under the ruthless domination of Furopean imperialism through the insidious trickery of hypocritical treaties. 32

30 Jomo Kenyatta, Facing Mount Kenya (New York: Random House, 1962) pp. 41-45.

$$
\begin{aligned}
& 31 \text { Ibid., p. } 46 . \\
& 32 \text { Ibid., p. } 47 .
\end{aligned}
$$


Kenyatta illustrated the Kikuyu and European relationship with a Kikuyu story. An elephant asked his friend, a man, during a thunder storm if be could put his trunk inside the man's small hut near the forest. Gradually he moved in completely, throwing the man out in the storm, saying he needed to protect his "delicate skin". 33 Hearing the ensuing argument, the other animals gathered around. When questioned about the disturbence by the lion, the elephant, a high minister in the lion's government, said, "I have only been having a little discussion with my friend here as to the possession of this little hut which your lordsin sees me occupying." The lion commanded that a Commisson of Enquiry examine and report about this matter and promised the man that he would be heard. 34

When the Commission, organized by the elephant, was formed, the man complained that no one from his side was appointed. He was told that no one could be appointed, "...since no one from his sjde was well enough educated to understand the intricacy of jungle law... The members of the Commission were all men of repute for their impartiality in justice, and as they were gentlemen chosen by God to look after the interests of races less adequately endowed with teeth and claws he might rest assured that they would investigate the matter with the greatest care and report impartialiy."35

$$
\begin{aligned}
& 33 \text { Ibid., pp. 47-48. } \\
& 34 \text { Ibid., p. } 48 . \\
& { }^{35} \text { Ibid., p. } 49 .
\end{aligned}
$$


In front of the Comission, the elephant claimed that

the man

"...invited me to save his hut from being blown away by a hurricane. As the hurricane had gained access owing to the unoccupied space in the hut, I considered it necessary, in my îriend's own interests, to turn the undeveloped space to a more economic use by sitting in it myself."

The other members, who were heard, agreed with the elephant's version. 36

When the man commenced his version, he was told

"...please confine yourself to relevant issues. We have alraady heard the circumstances from various unbiased sources; all we wish you to tell us is whether the undeveloped space in your hut was occupjed by anyone else before Mr. Elephant assumed his position?"

He was only given time, to answer, "No, but---"' before the Commission closed the investigation. AfLar being bribed by Mr. Elephant, the Comission reached a verdict.

"In our opinion this dispute has ariser through a regrettable misunderstanding due to the backwardness of your ideas. We consider that Mr. Elephant has fulfilled his sacred duty of protecting your interest. As it is clearly for your good that the space should be put to its most economic use, and as you yourself have not yet reached the stage of expansion which would enable you to fill it, we consider it recessary to arrange a compromise to suit both parties. Mr, Elephant shall continue his occupation of your hut, but we give you permission to look for a site where you can build another hut more suited to your needs and we will see that you are well protected. 37

This procedure was repeated until all the animals had new huts. The man felt that the Commission had not reached its

$$
\begin{aligned}
& 36 \text { Ibid, } \\
& 37 \text { Ibid., p. } 49-50 .
\end{aligned}
$$


decisions fairly. The man built another hut. Presenty all the animals tried to take possession of lhat hut. Disputes concerning ownership ensued. While the animals were arguing, the man burnt the hut and the occupants. As it burned he left saying: "Peace is costly, but it's worth the expense. " The man lived happily ever after. 38

Within the Kikuyu story, Kenyatta has shown a number of the grievances of the Kiklyu in the relationship with the Europeans, especially the issue of land alienation, the alien corrupt judicial system, the limitation of African rights, and the establishment and manipulation of government institutions and economic endeavours in the interests of the Europeans.

There was, of course, the nationalist and human desire to be recognized as a people whose rights should not be withheld for another fifty or one hundred years. This tale suggested that the Kikuyu should wait until the time was ripe. The Europeans would become so confused with their own teachings, practices, and competition with one another, and would eventual1y become so engrossed. with these affairs that they would be concerned with nothing else. It was an illustration of the complete disregard the Europeans had for the Africans except in relation to what the Africans could do for them. 38 Ibia., pp. 50-51. 
Was Kenyatta also suggesting that the Africans should reta1iate if there was no great improvement in their situation? Was he suggesting that violence be used if the Europeans did not alter their attitudes and practices? Was this leader advocating violence in order that the Africans obtain their human rights and control of their country?

One can not say definitively that kenyatta categorically agreed with these jdeas. Hovever, one should consider the fact that he has included this tale and has not criticized it.

Kenyatta criticized the European system of education for Africans because he felt that it did not provide the African with the ability to function either in the tribe or In the European society. This was because "...in the past there has beer too much of 'civilizing and uplifting poor savages." The policy had been based on the preconceived idea that the African cultures were primitive. Education provided by Europeans did not take into account the hopes and ideals of the Arricans. 39

The tribes had been disruptad more since the arrival of the Europeans than they were through pre-European tribal warfare, although the Europeans felt that they had done a service in stopping tribal warfare. Why was it any better to fight in European wars, e.g. World War I, to protect 
democracy?

The reward for this was taking away the best land from the African, the introduction of kipande with its diabolical system of finger-prints as though the Africans were criminals, imposition of heavy taxation and denial of freedom of speech, of press, and of forming political or social organizations. This is what "democratic Britain" did in recognition of the services rendered by the Kenya Africans during 1914-1918.40

Kenyatta opined that in accepting the European presence the African had been relegated to being a slave. Before the Europeans arrived, an African "...man was a man, and as such he had the rights of a man and liberty to exercise his will and thought in a direction which suited his purposes as well as those of his fellow-rnan." 41

Land was the basis of all aspects of life in the tribe.

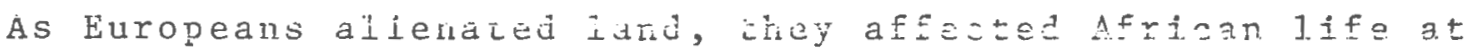
its roots. Länd was important for it ...not only unites the living member of the tribe but also the dead ancestors and the unborn posteri.ty... The dead are able to keep direct communication with the living, and the sanctions which control behavior in both the collective life of the tribe and private lives of its individual members are the approval or disapproval of the ancestral spirits. 42

Concerning the importance of land in the Kikuyu society, Kenyatta offered the following observations:

$$
\begin{aligned}
& 40 \text { Ibid., Pp. 203-04. } \\
& 4 I_{\text {Ibid. }}, p \cdot 204 . \\
& 42 \text { Ibid., p. } 42 .
\end{aligned}
$$


.. A culture has no meaning ipart from the social organization of life on which it is built. When the European comes to the Gikuvu country and robs the people of their land, he is taking away not oniy thejr livelihocd, but the matarial symbol that holds family and tribe together. In doing this he gives one blow which cuts away the foundations from the whole of Gikuyu Iife, social, moral, and economic. When he explains to his own satisfaction and after the most superficial. glance at the issues involved, that he is doing this for the sake of the African, to "civilize" them, "teach them the disciplinary value of regular work," and "give them the benefit of European progressive ideas," he is adding insult to injury, and need expect to convince no one but himself. 43

The Europeans limited the African's opportunities to share the material developments and ideas of the western civilization, e.g. medicine, advanced education. In those instances in which the African was allowed to share, the تUropears imfosed emsamely rigid rogulatinns. The Europeans harbored the attitude that it was better for the Africans to work for them. In order to insure that the Africans would work for them, the Europeans alienated the land. In addition, they greatly altered the governmental system and imposed Christianity, an alien judicial system, and morality. 44 Freedom was an integral aspect of African cultures and societies. Europeans had no appreciation of its importarce. The African would not tolerate subjugation. Kenyatta felt that it was necessary and inevitable that the Africans

$$
\begin{aligned}
& 43 \text { Ibid., p. } 305 . \\
& 44 \text { Ibid., p. } 305 .
\end{aligned}
$$


fight for freedom. The Africans should be under control of no other people or nation. If the Africans continued to be colonized, other nations would compete for control and the Africans would become increasingly weak. 45

In a letter written to The Times (London) in the $1930^{\prime}$ s, while residing in England, Kenyatta explained the aims of the African K.C.A. of which he was general secretary:

1. Land. To obtain a legal right recognized by the local government to the tenure of the lands held by our tribe before the advent of the foreigner, and to prevent further encroachment by non-natives on the Native Reserves.

2. Education. To obtain educational facilities of a practical rature to be financed by a portion of the taxes paid by us to the fovernment.

3. Woman's Hut Tax. To obtain the abolition of the Int Tay or. Tnmon--which leads to their being forced to work outside the Native Reserves, or into prostitution for the purpose of obtaining money to pay this tax.

4. Representation in the Legislature. To obtain the representation of native interests on the Legislative Council, by native representatives elected by themselves.

5. Tribal Customs. To be permitted to retain our many good tribal customs, and by means of education to elevate the minds of our people to the willing rejection of the bad customs. 46

If these aims were realized, Kenyatta felt it would be possible for Europeans and Africans to peacefully co-exist in East Africa as subjects of Great Britain. However,

$$
\begin{aligned}
& 45 \text { Ibid., p. } 306 . \\
& 46 \text { Delf, Jomo Kenyatta, pp. 69-70. }
\end{aligned}
$$


...the repression of native views, on subjects of such vitaj. interest to my people, by means of legislative measures, can only be described as a shortsighted tightening up of the safety valve of free speech, which must inevitably result in a dangerous explosion--the one thing all sane men wish to avoid. 4

Josiah Mwargi. Kariuki was detained during the Emergency by the Kenya Government allegedly because he was involved in'Mau Mav'. He described Mau Mau in his autobiography Mau Mau Detainee as a grass-roots movement which had no central direction. Kariuki stated that the Africans wanted to control the country and not allow the whites to continue to increase their domination. The Africans were preparing a group of educated persons to be able to take over the country, while movements for independence in other coun-

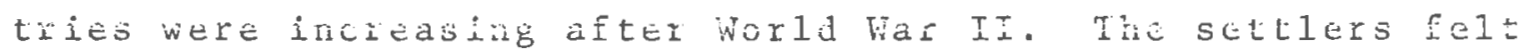
this and as a consequence tried to enlarge their power. 48

The Africans, by 1950, increasingly felt that their complaints were not being considered. When in 1951, the British Government refused to act upon moderate African demands concerning representation in the Legislative Council, "...a tougher attitude became apparent in the inner councils of the Africans." If any concessions had been made to indicate the British willingness to grant Kenyan indepentence under African control in the foreseeable future the Africans would not

\section{Ibid., Pp. $69-70$.}

48 Josiah Mwangi Kariuki, 'Mau Mau' Detainee (London: oxford University Press, 1963), p. 22 . 
have turned to Mau Mau. Fven as late as October, 1952, several political concessions would have prevented the revolt. However, the government instituted extreme measures against the Africans who felt they had no recourse except violence and rebellion. 49 Mau Mau used violence only when al1 other methods had failed to alleviate the African situation. Mau Mau grew only because other groups and individuals had not been successful in trying to bring about a situation in which the African would have self-respect and better economic, social, and political conditions. The government did not understand that Mau Mau was a result of extreme frustrations experienced by the Africans while attempting to express themselves through regularly established channels. 50 KAU, in the years prior to 1952, had tried unsuccessfully to have moderate advances for Africans instituted. The government vould provide few opportunities for African participation in the government. Jomo kenyatta was not allowed to be on the Legislative Council. This factor as well as the failure of the government to authorize political advances and concessions meant that extremists within and without the KAU were able to gain greater support. Those who were attempting to remain moderate began to lose support. Eventually, moderates became more extreme while trying to prevent

$$
\begin{aligned}
& { }^{49} \text { Ibid., pp. 15-16. } \\
& { }^{50} \text { Ibid. , p. } 23 .
\end{aligned}
$$


open conflict.

Our fair land was being sacrificed on the irreconcilable horns of the basic dilema of British policy in Kenya. The encourarement of European settlement and the entrenchinent of European privilege on the one hand, and the superficial lip-service paid to the ideals of democracy and African advance on the other.

If kenyatta had not been arrested, tried, and imprisoned, the situation could quite possibly have not developed as it did. Only kenyatta might have been able to moderate the extremists and prevent rebellion. He alone would have been able to restrain the revolutionaries. However, with his arrest, revolt was almost inevitable. 51 Kariuki disagreed with the contention that Kenyatta was involved with the oaths. Kariukj opined that

...the fact that many former KCA officials took an oath is not evidence that the two organizations were the same... [there is no] evidence in Corfield to justify his statement that Mau Mau was the direct offspring of $\mathrm{KCA}$. 5

The oath was developed spontaneously to unify the people who wished to maintain self-respect and to obtain independence when it was realized that there was no real progress through constitutionally established channels. When first utilized, the oath was not objectionable. The more the Africans became aware that cnly through unity, faith, and obedience could they possibly succeed against the

$$
\begin{aligned}
& 51 \text { Ibid, } p \cdot 19 . \\
& 52 \text { Itid., p. } 23 .
\end{aligned}
$$


government and the settlers. 53 "It was a war for our homes, our land, and our country in which the price of failure was death." 54 Kariuki conceded that some Africans, especially Kikuyu, were forced to take the oath. However, he stressed the fact that the government had exaggerated the number and that it dj.d so in its own interests. 55

'The effect of the oatin on the individual varied.

Some people were more receptive to taking the oath than others. The individual usually received little advanced notice of the time that he would be required to take it. Some other writers have stressed the fact that those who refused were often killed. Kariuki described his reaction to the first oath. He had not known until shortly before that he would be asked to participate, After taking the oath, Kariuki said, "... f felt exalted with a new spirit of power and strength. All my previous life seemed empty and meaningless. Even my education of which I was so proud, appeared trivial beside this splendid and terrible Force that had been given me." 56 He ras not offered a description of any of the other oaths, therefore we have no idea what his reaction to them was.

$$
\begin{aligned}
& 53 \text { Ibid. , p. } 23 . \\
& 54 \text { Ibid., p. } 32 . \\
& 55 \text { Ibid., p. } 32 . \\
& 56 \text { Ibid., p. } 27 .
\end{aligned}
$$


Generai China, Kikuyu Waruhiu Itote, one of several Mau Mau generals of the Forest Fighters forces, had fought with British forces in the Far East during Norld War II. During this period he had experienced "...no pride, no air of superiority from our European comrades in arms." As a result of the military experience he learned about military organization. 57

However, like many other Kenya servicemen, he had learned something which Itote felt was of far greater import: "I had become conscious of myself as a Kenya African, one among millions whose destinies were still in the hands of foreigners, yet also one who could see the need and the possibility of changing that situation." 58 He realized that Kenya" ".. was one of the last posts of feudalism, racialism, and minority privilege, and domination."59 The Africans could alter this situation and achieve independence within a generation he felt. 60

Mwangi Macharia, the founder of Anake a 40 (the Forty Group), had organized this group partly from men who were of an age-group who had fought overseas for the British and

57Waruhiu Itote, 'Mau Mau' General (Nairobi: East AErican Publishing House, 1967), p. 27.

58 Ibid., p. 27.
59 Ibid., p. 39.
$60_{\text {Ibid., }}$ p. 39. 
"... who had survived death and much hardship in the cause of a country which now seemed determined to block and humiliate then at every opportunity." 61

By 1950, some young Africans had expressed the desire to achieve indeperdence within three years. The militant spirit among the younger men was fostered by the attitudes and actions of the Europeans. The settlers had drawn up the "Kenya Plan": The Africans believed that this plan entailed Kenyai independence under settier control similar to the South African system of apartheid. "We [the Africans] even suspecied them [the Europeans] of grander designs still, of linking a White East Africa with a White Central Africa... to South Africa." 62

By the end of 1950 , Itote took the first "...oath of unity and dedication in the struggle for the freedcm of country... We were fighting with the weapons of Truth, Love, and Justice." 63 For Itote, there was "...nothing strange about people who already feel strongly about their freedom wanting to sanctify those feelings openly by taking part in a sacred oath."64 The oathing-ceremony served the purpose of unifying through traditional forms. The administrators

$$
\begin{aligned}
& 61 \text { Ibid., p. } 38 . \\
& 62 \text { Ibid., p. } 39 . \\
& 63 \text { Ibid., p. } 40 . \\
& 64 \text { Ibid., p. } 283 .
\end{aligned}
$$


explained the reasons they felt unity was especially necessary. In order to gain independence and the return of alienated lands, unity was essential.65 Each African had to be committed to the cause. Anyone who would not support the Mau Mau efforts to gain independence should die.66 Fventually, because of the cruelty of the colonial troops, a great proportion of the Africans preferred to assist the Mau Mau or Freedora Fighters, 67 rather than the government.

As the forest forces depended on support from the Africans for materials, information, and morale, Itote felt it necessary' to coerce or force people if they were not willing to take the oath. "The explanations which we gave, as We1.1 as the effect of the oath itself, hound the people to us and with understanding came co-operation." However, he denied that children were oathed. 68

By January, 1952, some Africans felt independence could rot be achieved peacefully through established channels. A "'War Council'" was organized. Some members of this council were also members of KAU. There was disagreement concerning the use of military tactics, especially between the older and younger members. Some members would not condone

$$
\begin{aligned}
& 65 \text { Ibid., p. } 50 . \\
& 66 \text { Ibid., p. } 52 . \\
& 67 \text { Ibid., p. } 114 . \\
& 68 \text { Ibid., p. } 64 .
\end{aligned}
$$


violence. 69 Supporting tive idea that force was necessary to obtain the rights and independence of the people, Itote quoted Kenyatta's specch made in August, 1952: "'...we must buy our freedom with our blood." 170 Military and propaganda training cf African forest forces and dissemination of propaganda commenced with determination on August 23 , 1952.71 Thus, before the Emergency, the Freedom Fighters were being groomed for their roles. However, General China felt that Mau Mau violcnce was only a reprisal for the Europeans' murdering of Africans. 72 The African forces would have preferred not to fight, but their "...militancy was literally forced upon" them. When many African political leaders were arrested at the beginning of the Emergency, they could only be submissive or resist. It was felt that by exhausting the colonial forces through guerilla attacks they could achieve their political objectives.73

Itote agreed with Kariuki in pointing out that among those in the movement were people who were trying to use it for their own purposes, especially criminals. The

$$
\begin{aligned}
& 69 \text { Ibid., p. } 43 . \\
& 70 \text { Ibid., p. } 45 . \\
& 71_{\text {Ibid. }}, \text { p. } 56 . \\
& 72 \text { Ibid., p. } 97 . \\
& 73_{\text {Ibid. }}, p \cdot 153 .
\end{aligned}
$$


motley forest forces included people who were committed to the fight for liberation; those who were captired and were afraid to go back to the reserves; and those who had joined to avoid being killed or detained by government forces. While the "thugs" or "ordinary criminals" operated for their own aggrandizement, the Freedom Fighters struggied to gain independence and to regain possession of the alienated lands.74 The chief motto of the Freedom Fighters was an old kikuyu proverb, "'none of our ancestors is alive.' By this slogan, we [the Freedom Fighters] meant that we must all one day die, and therefore we would fight until strength failed us, until our. death, or until we were victorious." 75

Although the expressed aims of the Mau Mau included independence from European domination, Itote opined that the Europeans would not be forced to leave the country. However, there was the possibility that those Europeans who had nothing to offer would be required to leave when Kenya became an independent country under the control of an African government. The Europeans wouid be utilized in training Africans for administrative and managerial positions. In addition, they would be needed as investment resources. 76

$$
\begin{aligned}
& 74 \text { Ibid, }, 141 . \\
& 7.5 \text { Ibid., p. } 114 . \\
& 76 \text { Ibid, p. } 208 .
\end{aligned}
$$


At least one African has collaborated with a white scholar in analyzing Mau Mau. Donald L. Barnett, an American anthropoingist, and Karari Njami, a Kikuyu who was involved in Mau Mau, report the latter's experiences and ideas in Mau Mau From Within.

Land alienation was one of the Kikuyus' basic grievances. The alienated African lands were to be used exclusively by the white settlers. The amount of land alienated was in excess of what could possibly be utilized by the whites. Even in 1940, more than i5,000 square miles of expropriated lands were not utilized for grazing or farming. As there was a shortage of African land, it had to be used constantly without opportunity to lay follow and to recover its fertility. Iittle improvement of agricultural techniques and a decrease in fertility led to a gradual decrease in productivity of Africar lands.

A steadily increasing number of Africans, especially Kikuyu, with 1ittle or no land, left the reserve and looked for work either in the towns, cities, or European farms. Occasionally, Africans were hired to work on lands which, if not alienated, would have been their own. Njami believed, "Alienation' then is a very appropriate term, for it contains the double meaning or connotation cf transference of ownership and losing something which nevertheless remains in existence over 
against one."17

In addition to the grievance about land, there were grievances concerning government taxes, salary regulations, African production and cultivation restrictions, and labor registration. The government's policies were designed to benefit the European settler. More and more, European settlenent was to effect a unity of the Africans, for there developed a broad base of interests in the landless and mobile African population. 78

Along with grievances, there were several aspects of Kikuyu society which contributed to the tension between the Africans and Europeans. The Kikuyu democratic tribal government was not centralized. The "legitinacy" of the government of the colony and of its laws were not recognized by the tribal political system. The age grade system "... wherein leadership emerged on the basis of demonstrated personal qualities such as skill, wisdom, and ability, "would not accept British-appointed chiefs. 79

In spite of the many grievances and the basically united African population

77 Donald L, Barnett and Karari Njama, Mau Mau From Within. Autobiography and Analysis of Kenya's Peasant Revolt. (New York: Month1y Review Press', 1966), PP. 31-34.

$$
\begin{aligned}
& 78 \text { Ibid., pp. 34-35. } \\
& 79 \text { Ibid., p. } 43 .
\end{aligned}
$$


....it is unlikely that the revolution would have occurred but for the integrative ideology developed over a period of thirty-odd years by numerous political, religious, educational, and trade union associations [KCA, KAU, independent church and school movements] which articulated and brolight in focus various African grievances and set forward certain political, economic, and social objectives. 80

A unity of interests and aims developed.

There was thus a good deal of overlap in both the leadership and rank-and-file membership of Kenya's African political, trade union, and church-school movements. This cross-linking of various Airican associations was tending to produce a single movement. 81

Until the middle of 1950 , KCA had restricted membership. At that time, the leaders decided to develop it into "an underground mass movement," 82 (whose members took an oath of unity) for they were beginning to believe that they would be unable to achicvé their objectives through established constitutional chaniels, and they began to fear that Kenya would become an independent nation under a settler government. The KCA realized that it might be necessary to revert to revolutionary tactics if moderate peaceful attempts through established constitutional channels by KAU's leadership failed. The situation did not improve. The government, at the insistence of the European settlers, attempted to suppress this African nationalist movement by silencing KAU and tribal publications, apprehending labor leaders, and, with few

$$
\begin{aligned}
& 80 \text { Ibid., p. } 35 . \\
& 81_{\text {Ibid. }}, p \cdot 41 . \\
& 82 \text { Ibid., p. } 61 .
\end{aligned}
$$


exceptions, prohibiting public meetings of Africans. The government did not consider or act upon the demands submitted by the Africans. 83

The aims of the Africans were expressed as

"Land and Freedom"... The tendency of this ideology to become more radical was a reflection oc the intensifying struggle between a subordirace African majority, increasingly aware cf its potential power, and a ruling European ininority, ever fearful that its privileged position night be svept away in the rising current of African nationalism. The pattern of events in this struggle should also be clear; constitutionai demands-government repression--militant reaction.84

Njami expressed the opinion that there were two series of events which led to the 1953-56 Mau Mau revolt. The first designated by ijani as "premature acts of violence" comprised such acts in 1952 as the murder of Senior chief Warukiu of kiambu and the burning of homes of persons in Nyeri district who were supporters of the government. These acts in all probability were connected with the initiation of the second oath by July, 1952, in spite of the fact that local leaders were most likely responsible. These acts of violence led to the development of a "revolutionary situation' for which the Movement was almost totally unprepared." The second set of events was initiated with the declaration of the state of Emergency, October 20, 1952. Because some Europeans acted as

$$
\begin{aligned}
& 83 \text { Itid., pp. 41-42. } \\
& 84 \text { Ibid., p. } 42:
\end{aligned}
$$


though this meant an "open season" had been declared on Kikuyu, Embu, and Meru, many Africans went into the forests. At this point, many more Africans decided that force was necessary to achieve their aims. The declaration of the State of Emergency "...was the major precipitant of rather than a reaction to Kenya's 'Mau Mau Kevolution." 85

Wj.th the arrests of many Kikuyu leaders alleged to be leaders of the Mau Mau movement, "...leadership passed into the hands of the now unlinked district and lower-level councils of Nairobi and the rural areas and a number of militant, though semi-educated or illiterate, local leaders began moving into the forests."86 People had various reasons for leaving the reserves and moving into the forests. Some who had had positions in the Mau Mau movement believed in the justice of the cause and believed that God would come to their aid. Some supported militant tactics; some sought the traditional security which the forest provided. Some were recruited after taking the "Warriors" Oath. Other reasons were hunger and fear of staying in the reserve. 87

The great percentage of those who became part of the Mau Mau forest forces were illiterate peasants. Although educated kikuyu agreed with the aims, they were opposed to

$$
\begin{aligned}
& 85 \text { Ibid, } \\
& 86_{\text {Ibid }}, p \cdot 67-72 . \\
& 87 \text { Ibid., p. } 120 .
\end{aligned}
$$


those practices which appeared to thein to be degrading. They also had to consider that they "had more to iose," especially materially. As the educated Africans had experiences and opportunities to appraise the government's power, they might have been much less optimistic about the chances of the Africans being at all successful. The forests did not seem to them to provide a satisfactory situation in which to maneuver. 88 "Though more likely an after-the-fact rationalization perhaps it was only the uneducated peasant, spurred by a confidence in Ngai's assistance not fully shared by the educated, who could muster the courage to attempt the impossible." 89

The aims of the Mau Mau are seen as inwo?ving various aspects, all of which were included for the primary purpose of unifying the African population. Among the many grievances there was the ".. desire to recover lost dignity, the surrendered 'manhood' of the tribe."90 In addition, there was the desire to improve the African's, especially Kikuyu, economic-political situation.

$$
\begin{aligned}
& 88 \text { Ibid., pp. } 150-52 . \\
& { }^{89} \text { Ibid., p. } 153 . \\
& { }^{90} \text { Ibid., p. } 202 .
\end{aligned}
$$


As a reflection of the developing relationship of tnequality between black and white in kenya society these secular aims were, in their political dimension, an expression of African nationalist ideology... symbolized in the demand for. "I and and Freedom." ..."freedom" was seldom if ever viewed as a specificaily Kikuvu or tribal objective, but ratier as the end-product of a successful African struggle vis-a-vis the Furopean adversary for independence from colonial and white settler rule.91

The issue of land alienation, however, was considered almost entirely as a tribal, especially kikuyu, concern. The attempt to achieve the aims of the Mau Mau movement "... were seen as sanctioned and legitimized by a higher, supernatural power." Since most of the activities and symbols which expressed this sanction were traditionally Kikuyu, e.g. the oath, this situation resulted in an almost exclusively Kikuyu movement. 92

Daughter of Mumbi, an autobiography by. Charity Waciuma, included comments regarding conditions and attitudes prior to and during the Emergency. Her family was educated and her parents important members of the Kikuyu tribe. These factors should, therefore, be taken into consideration when examining this book. She was influenced partially by her uncle who attended Makerere University prior to the Emergency. As a young child, she was aware of the conflicts which the presence of the Europeans had produced in the Kikuyu

$$
\begin{aligned}
& 91 \text { Ibid., pp. 199-200. } \\
& 92_{\text {Ibid., pp } 199-201} .
\end{aligned}
$$


society. The witch doctors resented the white man's medicine. They resented her father who had been trained by the white man to be a health inspector.93

Miss Waciuma was inquisitive abnut many tribal procedures, wanting to learn how many aisputes were settled. She was told that if the court was unable to djscover which party was telling the truth the people involved would have to take "Muina wa kuringa thenge'--to swear by killing a goat." Eventually, following the oath ceremony, the person who had not told the truth suffered fatal consequence. The elders were thus able to determine who had told the truth.94

Although Miss Waciuma accepted some aspects of western civilization, e.g. medicine, she aid not accept the European attitude of superiority. She realized the negative consequences of the European presence. With the Europeans' imposition of their civilization, many of the traditional African tribal customs and controls disintegrated or were disrupted. The Europeans forced the Kikuyu to reject the traditional tribal religion. As a result, they had no feeling of stability and were "an easy prey to corruption."95

93Charity Waciuma, Daughter of Mumbi (Nairobi: East African Publishing House, 1969), pp. 30-32.

94 Ibid., pr. $38-39$.

95 Ibid., pp . 43-44. 
The 1 aw of the white man drew ro respect. It did not appreciate the effective tribal laws which were respected and feared. In legal proceedings in the white man's court the Kikuyu had to swear to the white man's God. Swearing to the white man's God did not in most cases produce the desired result. This oath realiy meant nothing to the African. Before the coming of the white man, the eliers of the kikuyu tribe had provided control of corruption. However, with the coming of the white man who appointed e1ders, corruption increased greatly.96 The appointed chiefs often provided workers to the settler who needed cheap labor to care for their large holdings and to farm their cash crops. 97

Although some Kikuvu had superficially adopted Christianity, the Europeans used Christianity to their own advantage. The church condoned the alienation of land. The church exploited the African, saying that "as a good Christian one should not think of worldly possessions and riches."98 It was symptomatic of the feeling of insecurity produced by the confrontation of cultures in Kenya that there developed many new religions. Thase new religions would often integrate aspects of traditional religion with aspects of Christianity. 99

$$
\begin{aligned}
& 96 \text { Ibid., p. } 43 . \\
& 97 \text { Ibid., p. } 99 . \\
& 98 \text { Ibid., p. } 87 . \\
& 99 \text { Ibid., p. } 50 .
\end{aligned}
$$


When the Europeans first came, the Kikuyu granted them use of some lands as tenants, believing that they would leave.100 The desire for land and profit have been seen to be the overriding factors contributing to the presence of the Europeans and to their attitudes and practices. The interests of the African were not taken into consideration. The people who worked on the estates were people whose lands had been usurped by the settlers. ${ }^{101}$ According to Miss Waciuna, the displaced Africans

...became bitter, bitter to the roots, about the strangers who came and took their land. Before the White Man came they had the right to use part of the hundred of acres of their clan land and now they had to beg a tiny plot as if they were strangers in the country of their forefathers. 102

\section{Miss Waciuma stated that she}

...rapidly grew to dislike these white men who sometimes struck the grown men as if they were children and who indeed always treated us as if mentally and emotionally, we were permanently children.103

Even those who did hold some land were prevented from growing cash crops, especially coffee. 104 The Kikuyu came to believe that in order to have the government better serve the African concern, it was necessary to eliminate those African messengers and chiefs who catered only to the government's and the

$$
\begin{aligned}
& 100 \text { Ibid., p. } 91 . \\
& 101 \text { Ibid. }, p \cdot 52 . \\
& 102 \text { Ibid. }, p \cdot 99 . \\
& 103 \text { Ibid., p. } 106 \\
& 104 \text { Ibid., p. } 106 .
\end{aligned}
$$


settlers' interests. In addition to not being able to shape their ow policies, the Africans were humiliated constantly by the Europeans.

The settlers were worried about educating the African too much. The educated African would be" "..more equipped with the language and the knowledge of techniques with which to present the grievances and demands of his people." The settlers, particular1y those who had little education, felt threatened by the educated black. As a result, they often displayed the greatest discrimination against the blacks. 105 The settlers tried to limit African education to grooming laborers and servents cnly.106 The white man humiliated the African because the white man feared the African.

Miss Waciuma felt that the Europeans knew that the African would eventually be able to regain his lands.107 As Miss Waciuma learned more and more about the white man, she desired to attain a Western education so that she "...could help in turning him out."108 Many Africans felt it was of the utmost importance to be provided with the skills necessary to run the country. These skills would be utilized after the European government was overthrown.

$$
\begin{aligned}
& 105_{\text {Ibid. }}, \mathrm{p} \cdot 102 . \\
& 106_{\text {Ibid. }}, \mathrm{p} \cdot 10 . \\
& 107_{\text {Ibid. }}, \mathrm{p} \cdot 88 . \\
& 108_{\text {Ibid. }}, \mathrm{p} .59 .
\end{aligned}
$$


"..only by being educated can we [the African] claim oux rights. The White Man thinks he 18 superior but he fs only better educated." 109

Despite the fact that officlally the Africans were represented in the Leglslative Council by such Europeans as the missionarfes, thelr demands were not heard. The missionarles had no real incerest in representing African political demands. Their only concern was to gain converts. Many Rikuyu viewed the white man's God as a thief, who sent the Europeans to rake the African lands:" The church and the government were seen to be partners in a conspiracy to control the Africans and to gain the land. 110

In addition to not representing the African interests, the missionarles interfered with the traditional tribal customs. Miss Waciuma felt that female circumcision, if not made an issue of, would have died naturally. But as the misstonaries prohibited this practice, it developed into an oper avenue of revolt against the European control.111

As a result of the cultural conflict, educated Africans were often in the position netther of belng accepted frto the Western culture not of befing a part of the rraditomal culture. This produced much insecurity and instability.

$109_{\text {IbId., }} \mathrm{PP} \cdot 87-88$.

110IBId., PP. 89-91.

111 Ib1d.; PP: 89-95. 
As a tribe we [the kikuyu] have reached a critical age, waiting and hoping for a full. development to the way of life the white man has taught us to want. If he tries to hold us back at this point he will live to regret it. 112

When men returned from World war I they tried to develop various poljtical organizations in order to express some of the ideas and to put into motion some of the practices which they had acquired while serving in the British forces. As the government increasingly suppressed these organizations, the African grievances multiplied. Tha African leaders realized that their organizations must go underground. With the outbreak of World War II, the Africans were told by the British government and the allies of the fight for freedom and democracy. However, little opportunity was given for the Africans to be free and to participate in the democracy. Although several Africans were nominated to sit in the Legislative Council. (these were "yes" men), the government was more interested in considering the possibility of having Kenya become a white controlled dominion.113 Eleven elected members of the Legislative Council represented 16,000 Europeans. Until the late $1940^{\prime} \mathrm{s}$, the total five million African population of Kenya was represented by two or three white men appointed by the government. Africans felt that

$$
\begin{aligned}
& 112 \text { Ibid., p. } 91 . \\
& 113 \text { Ibid., pp. } 94-95 .
\end{aligned}
$$


they should be able to elect their representatives. The government said that the Africans did not have enough educated persons to be able to vote intelligently. Those Africans who were educated were thought by furopeans to be out of touch with the electorate.114

Although there were various groups of Europeans within Kenya, the Africans viewed them all as settlers, "...and attributed to all of them the wrongs for which... they held the settlers responsible." As a result of the lack of human respect which many of the Europeans evidenced, the African's gradually learned to hate the Europeans. 115

The settlers felt that the Africans had no legal right to the land which the Europeans claimed had been unused before their arrival. In addition to many grazing areas, the forest areas were often taken as well. The Europeans felt that their presence had been beneficial to the Africans. The kikuyu felt that aid was given only when it served the European interests. Some Kikuyu opined that they would prefer to have no aid if it meant that there would be no settlers,116 Europeane claimed that a great proportion of the money which had been brought into the country was used to pay Africans. Africans felt that the taxes levied on the

114 Ibid., pp. 104-05.

$115_{\text {Ibid. }}$ pp. 98-99.

116 Ibid, , p. 103 . 
Asians, Arabs, and themselves vere disproportionately higher than the taxes paid by the Europeans in Kenya. New agricultural methods and crops had been introduced; medical services and schools had been provided. The settlers argued that they had been induced by the government to come to develop the area. They felt they were magnanimous in providing the before-mentioned materials and services to the Africans. 117

Miss Waciuma believed that all Kikuyu had a deeper sense of grievance primarily because the kikuyu tribe suffered the most.

Who can wonder that we hate and distrust the settlers as a body? Why are we denied ways of making our views properly kinown? AlI they hear of our opinions comes from their lackey, the ahiefs. It may ue thil the governmert gave the land to the settlers, but we can see that it is the settlers who are in occupation. 118

There were no new lands into which to expand.

It was the opinion of the author

...that the major cause of friction between the African and the government in Kenya was that the District officers did not really understand the African point of view. What made it all the worse was that they thought they did. These officials made themselves trustees and guardians of what they regarded as backward and uncivilized people. 119

The Africans were humiliated by this treatment. The District Officer was all-powerfil. Many Africans, especially the

$$
\begin{aligned}
& 117 \text { Ibjd., pp } 100-105 . \\
& 118 \text { Ibid., p. } 101 . \\
& 119 \text { Ibid., p. } 106 .
\end{aligned}
$$


chiefs and headmen became "yes men" tu the District officer. The chiefs and headmen owed their positions to the District officer. Communication betreen the government, the District Officer, and the Africans was difficult. The District Officer generally ild not know any of the tribal languages. The Africans, except those who 1ived on the coast, did not have a strong command of Swahili of which the District Officer had limited knowledge. Written statements from the government often had to be translated twice--from English to Swahili and from swahili to the tribal language. In addition, before the District officer might learn about the ideas and the way of life of the area to which he had been assigned, he was transferred. However, Miss Waciuma felt that "worse than the stacling of the land, worse than the failure of communication was the lack of human respect."120 The revolt against the government and the settlers was seen by this young girl as the "Kikuyu Frecdom struggle."121 The fighting men were viewed as "true nationalists". As a result of the support the Mau Mau received from the people, the government made the Africans move into villages.122 The settlers wanted all kikuyu to be killed.123 When villages were attacked, many

120 Ibid., pP. 106-07.

12. Ibid., p. 111 .

122 Ibid., pp. 112-13.

123 Ibid.. p. 130 . 
young people vent into the sorest. The security forces often killed or critically wounded those people whose village had been attacked. Europeans no longer wanted laborers. Conditions in the villages were overcrowded. There was disease. Iittle water and food were availabie. 124

In spice of the governmert's efforts to prevent support of Mau Mau, Miss Waciuma stated that practically everyone, including loyalists, at least in her village, took the Mau Mau oath, except a few Christians. Many loyalists had been "...bribed by the government and the settlers with the promise of money, power, land, or salvation."l25 Many people in Miss Waciuma's viliage believed that if they endured pain and were strong they would eventually succeed.126

Miss Vaciuma felt that Jomo Kenyatta was considered by maly Kikuyu to be the greatest patriot. He had been "the ambassador of Kenya's Africans in England and Europe." He was looked upon as a savior. In order to keep up the morale of the viliagers against the oppression of the Fiome Guard and the government, many songs were adapted which conveyed the strength which kenyatta held. The following is an adaptation of a Christian hymn:

$$
\begin{aligned}
& 124 \text { Ibid., pp. } 116-18 . \\
& 125 \text { Ibid., p. } 131 . \\
& 126 \text { Ibid., p. } 129 .
\end{aligned}
$$


"Kenyatta shall reign where'er the sun Doth his successive journeys run;

His Kingdoms stretch from shore to shore Til moons shal wax and wane no more."127

127 Ibiu., p. 114 
CHAPTER V

WHITE NOVELS

A number of novels have been written about the Mau Mau revolt. The majority have been written by Europeans and Americans. Most of these were written before 1963--the year Kenya became an independent nation. The majority of novels which have been written since 1963 have been written by black Kenyans. Several of these will be published shortly.

Some of the novels have only a few references to the May Mau, while several have Mau Mau intricacely interwoven

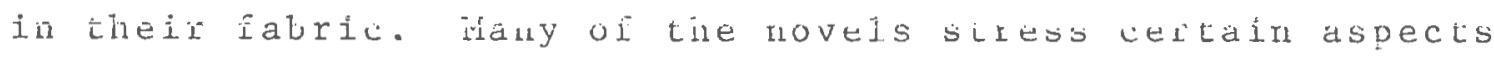
of Mau Mau, almost to the complete exclusion of other aspects of Mau Mau. One must remember that they are novels and not. historical treatises. Materials used in any novel are selected according to the purpose of the author.

Mollie Hamilton's Later Than You Think, a murder mystery, was set in the White Highlands during the latter part of the Emergency, in 1.958. This British author accompanied her husband to kenya in the 1950's while he was serving as a government administrator. Although by 1958, active Mau Mau and government forces' conflicts had been reduced, people believed there were stili men at large who had been actively 
irvolved, and that at sometime they night try to seek revenge against their former enemies, either the European settlers or the loyal Africans, for not all the Mau Mau had been arrested and detained. Despjte the feeling that the Mau Mau might be anywhere, many of the white settlers trusted their own servants to such an extent that they rould not believe that they could be members of Mau Mau. ${ }^{1}$

In Miss Hamilton's book, an English girl, who had come to live in Kenyil while conversing with a Eormer member of the Government Security Forces became angry about his keeping record of the Mau vau whom he and his men had killed. He replied that it was the Mau Mau who had been barbaric, emphasizing the horrors of the oath and the attacks on the white men. 2 In addition, this former member of the security Forces made the folloring comments about the purpose of the oathing ceremonies.

"It has been fairly conclusively proved that someone who kills once and gets away with it, will kill again ${ }^{3} \ldots$. That's why the initiation rites of any secret society of the Mau Mau description include a murder. Because it's only the first killing that is difficult.... The men we were aiter had deliberately bestialized themselves by acts and oaths and ceremonies that were so unspearably filthy and abominable that the half of them have never been printed, or believed by the outside world. If any of us were caught--and a good many of us were-me knew

LMolite Hamilion [M. M. Kaye], Later Than You Think (New York: Coward-McCanu, Inc., 1958) p. 16.

${ }^{2}$ Ibid., p. 87.
${ }^{3}$ Ibid., p. 88. 
just how slowly and unpleasantly we should die. You cannot conduct a campaign against a bestial horror like the Mau Mau with gloves on. Or you can--i.f you have no objection to digging up a grave in the forest and finding that it contains the body of your best friend, who has been roasted ailive over a slow fire after having certain parts of him renoved for use in Mau Mau ceremonials." 4

Continuing he spoke of one of the loyal Africans who had been working with the security forces since the Lari massacre in 1953. The Iari massacre was an alleged Mau Mau attack against the loyal Kikuyu living in Lari, a village in Kiambu. As a result of this attack, the whole European population became united against the Mau Mau. Many of the Kikuyu who had been sitting on the fence then came over to the government for by now they realized fully that this was no longer Nau Mau againgt whte settlers but also Mav Mou gajinst piluyu. 5 When the English girl mentioned that "...it is their [Kikuyu] courtry," he retorted that it was only through the work of the white settlers that the country had developed as it did, and that the settlers did not take the land from the Kikuyu, that only a part of it belonged to the Masai who were compensated with other land. He felt that only through the exhausive efforts of persons like Delamere was the land made productive. No one complained when the land was alienated.

$$
\begin{aligned}
& { }^{4} \text { Ibid. }, p \cdot 114 . \\
& { }^{\text {Ibid. }}=p p \cdot 115-16 .
\end{aligned}
$$


Only when these laras were made fertile did the Africans, citing "nationalism", demand the return of the land. HowEver, this settler felt there was enough land for the Africans to prove they were capable of ceveloping prosperous agricultural concerns. He believed, however, that the Africans could not achieve this objective for they did not possess the same mental faculties and perseverance as the Europeans. This settler planned to stay in kenya. Only if ordered by the Unjted Nations would he leave. 6

Look Not Upon Me, written by Denys Jones and published in 1955 was situated in Kenya before the Emergency was declared in October, 1952. In fact, some references indicate that the tale was set during the Second World War.

"...War or no war, it seemed most likely that they were working for some other alliance of the darkest kind. They might wait for the outer, vaster, war to end before they launched what was the consequence of their own grievances and hates. Meanwhile the little outbursts, murders, and outrages, occurred." 7

However, there were direct references to Mau Mau, so it would seem that either the author was exercising the privilege of a movelist to arrange time for the converience of hịs tale or he felt that the Mau Mau had started to develop during the Second World War. For example, when speaking about an

\section{${ }^{6}$ Ibid., p. 117 .}

7 Denys Jones, Look Not Jpon Me (New York: Criterion Books, 1955) p. 127 . 
attack on an Airican guard, an Afrjcan said that the attack was the work of: tịne Mau Mati. The African emphasized the terror of the Mau Mau by using words connoting death to the African. "'...It is Mau Mau, sir.... It is a word which is spoker out of the darkness, sir. A word at the fang-end of the spear, sir. It is the voice of the hyena's teeth, sir, chewing upon the meat of his eneiry. " 8

Although it was not designated as Mau Mau, the Europeans began to become aware that a secret society had been organized by the Africans, especially the Kikuyu, but they seemed to pay Iittle attention to it. ${ }^{9}$ More especially, they did not do anything to alleviate the grievances and the deplorable conditions of the Africans. Did the phrase "keep the red flag flying over Kenya'" mean that the kikuyu were developing dangerous situations in kenya? or did it imply that the Communists were involved in or interested in fomenting a revolt? 10

The author incorporated some of the Africans' grievances into the tale, e.g. the ideas of the white settlers and their position with regard to the Africans. When a British soldier questiored the manageress of a hotel as to why an African had been refused service and why there were

$$
\begin{aligned}
& { }^{8} \text { Ibid., p. } 33 . \\
& { }^{9} \text { Ibid }, p \cdot 272 . \\
& { }^{10} \text { Ibid., p. } 273 .
\end{aligned}
$$


rules prohibiting service, she answered: "'There aren't five milion of them in England, with only a handful of us to keep control over them. If there were, you would find the same kinds of rules as we have to have out here."11 The rules were part of the color bar which had been established in elmost all economic, political, and social activities. of the African. The Europeans had many servants who accepted the attitudes to the extent that they felt that the Africans should not try to change the rules. This acceptance may have been adapted only for expediency, or in the desire to achieve a sense of their own eminence comparnd to other Africans. 12 Learning of the murder of a European family, the soldier immediately assumed that it was tho Kikuyu who vero responsible. "Ha! Those bastards! I bet if anybody has done anything up here, that's who it is--kikuyus!'" However, an African reminded him that it was a kikuyu headboy who was trying to get help.13

The terror and horror of the deaths were emphasized:

"It looked as if some atrocious savage rite had taken place, some sacrifice of a sheep or pig or calf which obscenely and pervertedly had required abuse of a Europear bed and bedroom and the slashing of a woman's clothes and undergarments. A disgusting letier of flesh and entrails steamed, knotted and partly wrapped in bloody fragments of cloth and silk... Spurred by the knowleàge and proximity of such filth, [all was] such utter outrage to a 11 human credulity and sanity." 114

$$
\begin{aligned}
& 11_{\text {Ibid. }}, p \cdot 116 . \\
& 12_{\text {Ibid. }}, p \cdot 117 . \\
& 13_{\text {Ibid. }}, p \cdot 121 . \\
& 14 \text { Ibid., p. } 122 .
\end{aligned}
$$


Because of the var effort, the censor office did not allow ary macerial to go out that implied that the murderers were Arrican, although the governiment and the population believed thot this was so. "...official evasjueness. was prompted by the current necessity for smothering any suggestion of internal troubles...to present the enemy with some sembiarce of united fronts and comradeship in arms and shoulder-to-shoulder."15

Jones stressed the horror of the murders. One of the white soldiers realized, however, that although there had been biack murderers and thieves, there were some legitinate Africar grjevances and frustrations which the settlers should have considerad and alleviated. Otherwise, a revolt would easily develop. 16

Later, when talking to an African who was to become an important figure in the African drive for rights, the soldier was confronted with some of the other grievances of the Africans. The Africans desired equality between the races. Some Africans felt that Russia understood this desire, while the settlers and the British government did not. The British soldiers themselves exhibited the attitudes of the government, although military regulations prohibited the

$$
\begin{aligned}
& 15_{\text {Ibid. }}, p \cdot 126 . \\
& 16_{\text {Ibid. }}, p \cdot 127 .
\end{aligned}
$$


British from conceiving of the Africans as savages. These regulations in and of themselves vere an insult and humiliation to the Africans. 17

Throughout the novel, one is increasingly given the impression that the whites and the army were becoming more aware that something was developing with the Africans, but that nothing was being done to alleviate the problems. Also, they were becoming aware of a change in the attitudes of the AEricars towards their work and towards the Europeans. The Africans seemed to be part of something else while at work. They seemed to be closed into themselves and to be reaucing any interaction between themselves and the Europeans. Interaction between Europeans and Africans was extremely jimited. While accepting some of the ideas and trappings of the Europeans, the Africans were also developing or trying to develop their own life which would be apart from the European life. The Arrican in responding to the soldier, emphasized that, in the future, African ideas and opinions would count. This African was working to gain African control of the government and the nation. However, one was left with the impression that the means for accomplishing this might be violent. 18

17 Ibid., pp. $277-78$.

$18_{\text {Ibid., pp. } 277-78}$ 
There dij not seen to be any cooperation on the part of the government in trying to solve these problems. The government should have at least acknowledged the problems and developed governmental programs in which Africans could participate to solve these problems. There seemed to be little concern with why these murders had occurred. There did not seem to be any real comprehersion of the reasons.

Henry de Montinied in his Sous 1 a Masule Mau Mau of fered a number of observations in his preface concerning the Mau Mau. He implied that the Russians had contemplated using Jomo Kenyatta for he appeared to be the "...precise instrument of dis order to break up the most beautiful. English colony." Kenyatta went to Russia at the invitation of stalin, who requested him to compose a Swahili-Russian dictionary to be utilized by the Russian embassies. The independent school pupils in Kenya were acquainted with soviet methods. 19

The independent school pupils became part of "secret society founded by Jomo kenyatta under the cover of KAU." KAU members whose greeting among themselves was Mau Mau were called Mau Mau. de Montfried contended that Mau Mau had no meaning, but that Mau was the kikuyu name of one of the mountains in the Abedare range. Kenyatta had gone into seclusion there on several occasions. The represcntatives to leaders of regional groups were required to give the password

19 Henri de Monteried, Sous la Masque Mau Mau (Paris: Gossett, 1956) p. 1.1. 
Mau to which a guard answered Mau, hence the term Mau Mau. 20 By 1947 , the goverriment had put a price on Jomo Kenyatta's head. He was subsequently arrested while in the hospital. 21 Jomo Kenyatta and others were distressed by the government's lack of concern about the African's grievances. 22 Kenyatta and others tried to convinice the government of the need to alleviate forrendors political, economic, and socjological conditicins. de rontfried seeme! to sympathize with at ieast some of the African grievances. Africans were victims of European practices and attitudes, de Montfried felt. He was not optimistic about the possibility of drawing up peaceful solutions to the grievances. 23

The grievances of the Africans included not only the 1oss of land (this author constantly referred not only to the destruction of forest areas but also to the takeover of grazing and farm lands) and the necessity of working for Europeans in menial positions, but also the necessity of fighting for England in the Second World War where the blacks were taught to kill white Germans. These black Kenyans realized, as a result of this experierce, that only their skin color differentiated them from the Europeans. After the Second World war, the revolt developed, accompanied by the murder of white

$$
\begin{aligned}
& 20 \text { Ibid., p. } 13 . \\
& 21 \text { Ibid., p. } 15 . \\
& 22 \text { Ibid., p. } 14 . \\
& 23 \text { Ibid., p. } 16 .
\end{aligned}
$$


settlers. 24 Tncreasingly, =olonists brought about the revolt by tryjng to ancrce laws which discriminated against the Africars. 25

The power of magic and oathing over the African "... which too easily we [whites] cheapen because to us it is inconceivable," was recognized by this author. He suggested that inability to accept its potver was because "...our [white] spirit has come from a very different evolution."26 de Montfried described several oathing ceremonies. In one ceremony, the oath taker swore "...in the name of right, liberty, and justice... [to cause] the blood of our oppressors redden and make fertile the soil they have stolen." The oath taker also swore to be loyal. to the "virtues of Man Mau" which included obedience and perseverence.27 A number of oathing ceremonies were held around the countryside, while waiting orders from Jomo Kenyatta who was still in England. 28 This meant that de Montfried felt that oathing had begun before 1946 or that he was using time sequences at his pleasure.

$$
\begin{aligned}
& 24 \text { Ibid., pp } 18-19 . \\
& 25 \text { Ibid., p. } 19 . \\
& 26 \text { Ibid., p. } 77 . \\
& 27 \text { Ibid., pp } 186-87 . \\
& 28 \text { Ibid., pp. 189-90. }
\end{aligned}
$$


de Montfried described a second oathing ceremony, details of which he claimed he heard from a servant. Before the juitiate sure the oath, the eyes, the stomach and the genitalia vere cut out of a living goat and put near an arch of banana leaves, while the head of the goat was impaled.

The initiate was then cut and toid to swear:

If ore oxders me to bring the head of my brother may this oath kill me with all of my family if I refuse. If one orders me to bring the finger and ear of my mother may this oath kill me with all my family if I refuse.

If one orders me to bring the head of an European may this oath kili me with all my family if I refuse. If I do not submit inyself to the oath of the Mau Mau this oath will kill me.

-If I reveal the hiding place of my brother may this oath kill me with all my family if I refuse.

If I see one of my brothers steal from a European

I swear to sav nothing or inay this oath kill ne with

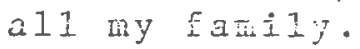

If I say a word to save a European may this oath kill me with all my family.

After swearing the oath, every villager passed through an arch. The men ate the entrails and drank the blood of the sacrificed goat; however, the women did not partake in the eating. 29

The Mau Mau movement, by 1949, was sti11 in stages of development. de Montfried felt that it "...had not yet taken on the character which the terrorists added to it with the refinements of cruelty." de Montfried opined that later

29 Ibid., pp. $192-94$. 
the movement vas to incorporatc "..more sadism than of the traditional black magic which had formed the soul of the peoples of Central Africa."30

One of the major questions in Neil Sheraton's African Terror was that of foreign intervention. His hero saw the possjoilities of great development, especially economic, both in the interests of the white and black man in Kenya. If the Africans pushed the whites out, Sheraton wondered whether the former would be able to progress as weli without the assistance of the latter. ${ }^{31}$ He seriously considered whether a foreign power was instigating the Africans to revolt in order to push out the British. 32 Many factors seemed to point to the Germans. One of the settlers whose fainily was murderea by the Mau Mau had opined that the Germans were resporsible for inciting the Africans to rid themselves of the British. This settler felt that the Germans were trying to build an empire from Fast to South Africa. At least they wanted to control East. Africa. 33 Although a number of Germans were involved with the terrorists, they were primarily businessmen who were interested in, making a profit from the sale of arms and munitions. 34

$30^{\text {Ibid., p. } 194 .}$

31 Neil Sheraton, African Terror (London: Robert Hale Ltd., 1957) p. 30 .

$$
\begin{aligned}
& 32 \text { Ibid., pp. 1.5, 109-10. } \\
& 33 \text { Ibid., p. 59. } \\
& 34 \text { Ibjd., pp. 121, 156-57, 172, } 176 .
\end{aligned}
$$


One Chitstian black African loyal to the government described the movement's development. The Africans believed that

...Almighty [God] is a white man. He builds churches for Africans to attend and when they put their money into the collection boxes the Lord uses this money to buy farm land for wite men. The vhite man make much profit for tivemselves from African crops and they pay Africans sinall moneys to work their lands. The African works hard and becomes too tired to think, and on his day off he goes to church and so god tells him to work some more and put more money in the boxes. 35

This black Christian continued to explain that the terrorists (the Mau Mau) preached a new religion which advocated the killing of all whites and all black Christians. Africa would be controlled by black Africans. They would no longer pay homage to the white man's God, but would worship their own God.

Although religion was stressed, its importance lay in the fact that religion was being developed by Africans in order to gain political control. In order to accomplish this, material aid was recruited Irom interested whites. These whites were particularly concerned with their own profit and not with the interests of the Africans. The profit was not only from the sale of arms. The Europeans sold advice in "the art of leadership." 36

$$
\begin{aligned}
& 35_{\text {Ibid. }}, \text { pp. 1i-12. } \\
& { }^{36} \text { Ibid., p. } 172 .
\end{aligned}
$$


The methods and procedures of killings were thought to be part of the religion which was developed and strengthened through the use of oaths. Many Africans had been forced into oathing; ". .once they had taken [the oath] they knew they were doomed, that they'd sold their souls, and so thev carried out their appointed tasks biindiy, rather than suffer a terribie, agonizing, tortuous death."3\% It seemed that quite a number of the Africans had to be persuaded originally by physical force to join the terrorists. They did not join voluntarjly and they did not join for political or ideological reasons. They were tortured and threatened with worse consequences if they betrayed Mau Mau. 38 Sheraton thus conveyed the idea that many Africans who were part of Mau Mau joined those forces only decause their lives and the lives of their families were threatened.

Another European in the novel described the African terrorists as "...fanatical, raving monsters who do every antiChristian and innunan deed for some crazy ideals that they can't understand themselves."39 The African fighters were considered by whites to be beasts and their techniques of murder were described in detail emphasizing the horror. For

$$
\begin{aligned}
& 37 \text { Ibid., p. } 157 . \\
& 38 \text { Ibid., p. } 11 . \\
& 39 \text { Ibid., p. } 48 .
\end{aligned}
$$


example, a man's decapitated head had been stuck on the top of a spike driven into the ground. 40

In his foreword, Sheraton set readers to expect savagery. Africa was a continent of the unknown and the little that was known seemed to smack of barbarism. "There is always sone kind of terror in Africa because it is a continent of conflicting moods and emotions, where anything and everything can happen."41 The temper and the attitudes were pictured: "Everyone [the suropeans] here has a gun and they can use 'em. If a woman sees her husband hacked to pieces by a damn black terrorist--t'aint in ccid blood that sine shoots--eh?"42 Sheraton emphasized the horror Africa holds for the Eurcpeam. However, I suggest that nne should keep in mind the fact that Africa appeared to be "dark" to the European for psychological. and intellectual reasons. Many of the Europeans who had settled in Africa had little comprehension of the existing African societies and the customs of those societies. They integrated their lives very little with these societies.

When this book was written, the Furopeans themselves were recuperating from the Second World War. This war was a highly mechanized operation. The guerrillas of the Mau Mau movement were forced to resort to more intimate attack because they lacked the sophisticated weapons of war. One of their

$$
\begin{aligned}
& 40 \text { Ibid., p. } 61 . \\
& 41 \text { Ibid., forward. } \\
& 42 \text { Ibid. , p. } 7 .
\end{aligned}
$$


primary weapons was surprise. It was necessary for them to be close to their victim in order to be sucressful, since their weapons could only be ased at short range or directly. Perhaps this nore direct hand-to-hand, face-to-face combat was more terrifying to the European because of the human contact. The Europeaus had become more accustomed to the type of war where machines play an important role and where men vere just extersions of the machines.

The Tribc That Losi. Its Head was claimed by its author, Nicholas Monsarrat, to be entirely fictitious. The events took place on Pharamaul, an imaginary island off the coast of South West Africa. This island tuas a British colony and was administered by Britist officials. The two major groups or trikes were the Maulas and the U-Maulas (as a result of an argument the latter had broken away from the Maulas). Was it a coincidenee that the names of the tribes and the island were variations of the word mau? The implication might be that the author was writing about the events in Kenya colony. Within the novel, there were several references to the Mau Mau. One of the leaders of the revolt against the British administration was described as trying to get "...the black man in and the white man out--now." It was suggested that there were similarities with the Mau Mau. 43

${ }^{3} \mathrm{Nicholas}$ Morsarrat, The Tribe That Lost Its Head (New York: William Sloan Associales, 1955), pp. 125-26. 
There were a number of factors which contributed to the explosion within the tribe and to the tribe's revolt against the 3ritish administration. The resident comissioner was portrayed as a mail who felt that his "'...backward sons [tl:e Africans]... would never quite grow up." 144 Although he adnitted that evertually the Africans would be able to govern themselves, he felt it was his and the British colonial administration's responsibility to look after them until such time they were prepared sufficiently for self-government. ${ }^{45}$

The new Eritish-educated Maula chief, Dinamala, felt at the time of his return from England to assume his position, that his people were not reacy to govern themselves completely. 46 His London friends, who were not acquainted with the situation, argued theoretically that the Africans of Pharanaula should receive immediate self-government. They were but another element in this complex situation. 47 The new chief became the focal point of the situation and was a symbol of the conflict between txadjtion and new ideas. Several young british-educated members of the tribe revolted against Dinamaula's avowed policy of initiating change through established channels. ${ }^{48}$

$$
\begin{aligned}
& 44 \text { Ibid., p. } 8 . \\
& { }^{45} \text { Ibid., p. } 9 . \\
& 46 \text { Ibid., p. } 17 . \\
& 47 \text { Ibid., p. } 17 . \\
& 48 \text { Ibid., pp. } 63-64 .
\end{aligned}
$$


There were many different pieces of wood that kindled the explosion. Although the British administration was trying, it thought, to serve the interests of the people under its charge, it was unsuccessful in many instances because of a distinct lack of communication between the African population and the adrinistration. 49 The British officials, at times, vere not aware of what caused changes in the African attitudes. They were not able to alter conditions which were responsible for changes in outlook. The officials were not able to commicate the rationale for those conditions to the Africans. The government which may have wished to act in the best interests of the "natives" had difficulty in explaining the purposes of its policies. 50 One government official expressed the problem in the following manner:

...it was impossible to find a policy which everyone in any given "dependent country" found adequate. If Britain granted independence too early, the country concerned became a prey to the corrupt, or worse still to the inefficient. If she held on too long, she might be blown out by thugs and replaced by political gangsters. If she held on indefinitely, she was pilloried as a colonial cespot or Fascist saboteur, reviled by half her own electorate. cursed by the Americans, burned in effigy by the Indians, and self-taxed to extinction in order to pay for it all.5I

As conflicts worsened, communication decreased. The agitation of the foreign press exacerbated the situation by incomplete and slanted reporting iacreasing outside involvement

$$
\begin{aligned}
& { }^{49} \text { Ibid., p. } 326 . \\
& 50 \text { It,id., p. } 343 . \\
& 51 \text { Itid., pp. } 574,583 .
\end{aligned}
$$


and misunderstanding. Thejr reporte tended to make each side's position less Elexible. 52

With the introduction of twentieth century ideas and practices, particularly political and economic, the tribal inembers were caught in an extremely stressiul period in which the new ideas were coming into contact with, and in many cases into conflict with, tradition. The transition of the society into the twentieth century was too rapid to allow the society to examine carefully and to adapt ideas and practices which suited its own situation and background. The trital members were trying often to adopt ideas and practices which were without background in their own society and which needed time and experierce to integrate successfully.53

Many of the men who initiated the revolt against the British administration and who wanted self-government did not act in the interests of the tribe, but were primarily acting in their own interests and in their desire to gain power and position. With the exception of the new chief, the men who led the revolt did not feel a real sense of responsibility for what they advocated and instigated. Their creed was hardly definable in terms of political ideology--black rationalism. "It was not communism. It seemed to include no whjte men nor any sense of tribal hierarchy either; it

$$
\begin{aligned}
& 52 \text { Ibid., P. } 314 . \\
& 53 \text { Ibid., p. 309, 357-58, 492. }
\end{aligned}
$$


included only personal power for whoever could grasp it." Their cry "'Freadom for Pharamaul' might mean anything from political justice to political tyranny."54 one of the revolutionaries promised power in return for each person's vote.55 The revolutionaries criticized the color bar which prevented the blacks from enjoying the same rights, privileges and responsibilities as the whites. The chief was instigated by a European reporter to challenge the color bar in a hotel bar. The weak line of communication was again evidenced. The chief was provided no way to alter his position without losing face with his own people. The differences between the government and the Africans became even more acute and more difficult to resolve peacefully. Each side operated without full understanding of and appreciation of the actions and posture of the other. Each became less flexible and tolerant.56 A government official, who purportedly had the interests of the Africans at heart, when asked about the color bar was reported to have said, "A colour bar? Nothing of the sort. But naturally a black man couldn't drink with a white man, eh? That was going a bit too far."57 Although this official believed there would be improvements in the African's situation, these were to be accomplished slowly. 58

54 Ibid., pp. 63-64.

$55_{\text {Ibid., }}$. 271 .

${ }^{56}$ Ibid., Pr. 275-76.

$5 \%$ Itid., p. 308 .

58 Ibid., p. 308. 
The revolutionaries, in order to develop a more

closely knit group of leaders, performed oath ceremonies to prepare themselves for a "blood battle". This oath-taking bound them through degradation for "...they were exiled beyond the pale of normal living, doomea cr dedicated to a pach of hatred and violence." The oath-taking forced the participant to promise to force all white men out of the country by murdering them, if necessary.59 This ceremony stressed the inhumanity of man. It emphasized those aspects of his nature which were of an animal nature. The description of the'capture, torture, and death of the district commissioner, his wife, and a priest depicted those Africans responsible as animals. The three bodies were defiled. The attackers used some of the body parts for other oathing ceremonies. The district commissioner's wife was cruelly and repentedly violated; entrails of the bodies were pulled out, and the priest was hung on a cross to die a slow torturous death. 60

Monsarrat was horrified by the alleged cruelty of the Africans. Monsarrat seemed to support the position of the colonists and the government. However, he realized that there were some circumstances, e.g. lack of communication, for which neither side was completely responsible. The Africans were experiencing the conflicts of a society in a

$$
\begin{aligned}
& 59 \text { Ibid.. p. } 279 . \\
& 60 \text { Ibid., p, } 541 .
\end{aligned}
$$


transitional state. Monsariat felt, however, that some segments of the African population were attempting to move too rapidy into the twentieth century. They were not yet capable of assuming the responsibilities of governing themselves.

Robert Kuark introduced his novel Something of Value with a Basuto proverb: "If a man does away with his traditional way of living and throws away his good customs, he had better first make certain that he has something of value to replace them." 61 one should take into account what had caused a man to give up his traitional way of life. Had this been his own decision? If this decision had been made for him, how deeply had the new culture been explained and transmitted? One may infer from this novel that Mr. Ruark did not think that the Africans, more particularly those Kikuyu who became members of or who were sympathetic to Mau Mau, had iound something of value. The Mau Mau had destroyed a way of life which had not yet been replaced.

To a certain degree, Ruark's attitudes reflect those of a number of Europeans, both inside and outside Kenya. The ecomomic structure and development of Kenya colony depended greatly on the overabundant and cheep labor force available to the settlers. 62 one of the young European settlers in

61Robert Ruark, Something of Value (New York: Porket Books, 1957) Opening quotation, no page number given.

$$
62 \text { Ibid., p. } 450 .
$$


Ruark's novel, before the Second World War, mentioned to a teenager

...you aren't going to see the white man and the African on even footing out here. There's no place in the scheme for it for. a long time. These people just aren't out of the tree jong enough. They were eating each other and seling each other just yesterday. 63

The responsibilicy of the Europeans, as they saw it, was to provicie positions for the Africans, but to limit their education and their Jevel of expectation. 64

The whites felt it necessary to protect their positions as they were so greatly oltnumbered. In kenya, each European was' outnumbered by two hundred Africans. They felt they could protect their own interests only by controlling through social, economic, and legal practices ${ }^{6}{ }^{\text {the }}$ activities of the Africans who were conceived as being little more than savages.66 Before the Second World War, as well as during and after, the Africans resented the treatment meated out to them. Their position was attributed to their color. Thejr resentment grew to the extent of wanting to kill.

\section{Ruark mentioned that the Africans wanted primarily} the material goods and power which they saw the white Bwanas (masters) 67 possessed. Few Europeans realized that their problens had developed as a result of the contact of the new

$$
\begin{aligned}
& 63 \text { Ibid., p. } 45 . \\
& 64 \text { Ibid., p. } 45 . \\
& 65 \text { Ibid., p. } 219 . \\
& 66 \text { Ibid., p. } 1.05 . \\
& 67 \text { Ibid., p. } 66 .
\end{aligned}
$$


Testern culture or civilization with the traditional African patterns of lise and thought.68 Few people realized that much of the African way of life and thinking had been uprooted and in many instances destroyed when tradicional laws and customs were banned. Nothing relevant and meaningful to the African was substicuted.69 Many of the recruits of the Mau Mau movement were the rootless young people who had left the farms in dissatisfaction with the altered traditional patterns. They moved to che cities where they were employed in menial tasks by the bwanas or became thieves, spivs, or bums. 70 Many Europeans felt that the Africans were not prepared sufficiently to participate in making any of the decisions and lavs wich would affect the iives of all the people. The Africans were not allowed to participate in the government. il

Even before the Second World War, the Africans were concerning themselves with learning the ways and knowledge of the white men. They realized the importance of the white man's education. In order to compete with the white man, to become an equal, and to rid themselves of white control, it was necessary to acguire the white man's knowledge. 72

$$
\begin{aligned}
& 68 \text { Ibid., p. } 222 . \\
& 69 \text { Ibid., p. } 222 . \\
& 70_{\text {Ibid. }} \text { p. } 329 . \\
& 71 \text { Ibid., p. } 225 . \\
& 72 \text { Ibid., p. } 66 .
\end{aligned}
$$


One of Ruark's princirie characiers, a European settier, was a chjldhood friend of a kikuyu who became a Mau Mau genera1. The European gradualy came to realize how the conditions in Kenya spanned the Mau Mau. The Europeans

..had civirized the outside of him ithe Mau Mau general ḱmani in particular, and Mat Mau in generall and forgot all about his insides. They slapped a coat of paint on hin and that's supposed to hide the Esct that his insides are just as icaming with iemons and full of darkness as hjs grandfather's insices were...civilization takes over and good-kid Kimani becones a thug and then a murderer and Einally a Man Mau general. You multiply hin by a few thousands...they weren't kinani any more and they weren't white men either. They were cirilized enough to want cars anc radios and to use guis and steajing to get cars and radios, when everyone of them was still a naked savage underneath the spiv suits and the yeilow shoes. We educated them and made them want things and took away their old securities and then didn't give them any other securities to replace what we'd taken. We gave them want and didn't give them any way to gratify wants... So now all the old ceremonies have been jazzed up to spell Mau Ma. 73

Even before the end of the Second World War, some young men formed a group called "the Forties". Its arowed purpose was to regain land, to re-establish traditional customs ard way of life, and to rid the country of the white man.74 Mau Mau was partially an outgrowth of this group. One of the leaders claimed to have given the name Mau Mau which had no meaning asserting that "...it is a very short name and will fit nicely into newspaper headines."75

73 Ibid., P. 593.

74 I.bid., F. 297 .

75 I bid., p. 318. 
In Robert Ruark's 1952 preface to his Uhuru [Freedom] he accused Jomo Kenyatta of being the head of the Mau Mau and of being responsible for all the destruction and violence in Kenya. Ruark claimed that kenyatta planned and developed "..the massive operation of murder."76 Ruark's concern. was prinarily for the destruction brought about in the 1ives cf the Europeans during the Mau Mau.77 Ruark blamed people who were "...city dwellers and detribalized wenches" for preventing, a peaceful consideration of grievances.78 He blamed kenyatta for using these people "...to do the dirty work" for he was powerless "... When the thugs ran wild. Al1 the planning went for nothing."79 Ruark believed the superficial grievances of the Mau Mau were exaggerated and developed by these people.80 Ruark seemed even more vehemently opposed to the blacks' demand for selfdetermination and self-government. 81

They couldn't spell freedom, let alone define it, much less practice it. Their freedom was a freedom to kick the hell out of each other. Uhuru. And how will you have your uhuru when it comes? In a package or in a bcttie? 82

76Robert Ruark, Uhuru (New York: Fawcett World Library, 1962) preface p. VII.

$$
\begin{aligned}
& 77 \text { Ibid., pp. } 25,55-56,139 . \\
& 78 \text { Ibid., p. } 194 . \\
& 79 \text { Ibid., p. } 200 . \\
& 80 \text { Ibid., p. } 194 . \\
& 81 \text { Ibid., p. } 74 . \\
& 82 \text { Ibjd., p. } 85 .
\end{aligned}
$$


Ruark mentioned that many of the people who were a continuing force behind the Mau Mau were never caught, often continuing to hold government positions. If the settlers had been allowed to deal with the situation, it would have been settled more eficiently. One of the European settiers commented: "...As it was it cost a bloody fortune and proved nothing excapt that the only thing a coon really understood was a boot in the backside."83 Ruark envisioned a retaliation by the blacks for their treatment by the whites and government during the Emergency. 84

Tile purpose of the Mau Mau was to eliminate the white man, to return the land to the Africans, and to "...creale our [African] new nation outsidc tha cld structure." 85 With the start of the uprising, Jomo kenyatta, among other leajers of the Mau Mau, was jailed. With the beginring o: the use of force by the Mau Mau, Jomo kenyat a no longer controlled the organization. Mau Mau orientation charged from political to criminal under new leadership willch drew primarily on the criminal elements of the society.86

83 Ibid., p. 116.

84 Ibid., p. 140.

85 Ruark, Somethirg of Value, p. 322.

86 Ibid., p. $538-39$. 
Mau Mau eventialiy cane to be directed on the premise that Mall Mau would be "...so terrible that not to be a member of it is worse than being hanged by the serkali the governmert police]."8? Terror would either be administered subtly or violently by the Mau Mau. The Africans were to attack the Europeans for whom they had been working. 88

Thjs revolt against the white man as conceived by many of its leaters would be accomplished by violence, including murder, arson, robbery, and the destruction of animals. The revolt was not to begin until the leaders believed that most of the Kikuyu had joined Mau Mau. This meant women and children as weil. By having the majority of Kikuyu as members it was hoped that all would give aid. Death was to be the answer for aryone who refused to become a member. 89 The members were to be initiated in oathing ceremonies. The following description of an oathing ceremony was given by Ruark. The oath adninistrator cut the wrist of each participant. The blood from each was mixed with the blood of a dead Tilan and a dead boy. Each person was then required to take seven sips of the mixture. After each participant completed

$$
\begin{aligned}
& 87 \text { Ibid., p. } 318 . \\
& 88 \text { Ibid., p. } 318 . \\
& 89 \text { Ibid., p. } 325 .
\end{aligned}
$$


this aspect of the ceremory, he was required to take sever tastes of a mixture of the brains of the too dead individuals, while repeating the oath which began"... if I am ordered to bring my brother's head and I disobey the order, this oath will kill ine." 90 me oath which Ruark cited in i.ength was the same as that cited by deMontried.

As more people began to resent the Mau Mau, scronger oaths were developed. The oathing ceremonies became "...simply orgies of obscenity."91 one of the settlers claimed that the oathing ceremonies involved "...fornication with animals and the drinking of unspeakable things."92 In Uhuru one of the settlers was abducted, later killed, and dismembered. His parts were ircorporated into an cathing sacrifice.93 In another oathing ceremony, the heart and brains of a small child whose father had refused to take the oath were used. The father was forced to watch his child beirg killed and then was forced to eat several parts of the body.94 Not only was Ruark concerned about the use of the humans in the ceremonies, but a 1 so about the maiming of animals. 95 In Uhuru,

90 Ibid., pp. $360-61$.

91 Ibid., pp. $538-39$.

${ }^{92}$ Ruark, Uhuru, p. 497.

93 Ibid., p. 56.

94 Ibid., pp. $70-71$.

95 Ib.d.,$~ p .74$. 
published the year before Indeneadence, Ruark asserted that ninety percent of the black adult population had been oathed.96 In Somethino of value he claimed that ninety percent of the adult Kikuyu population had been oathed.97

The Mau Mau planned, pending success in enljsting the rikuyu tribe to revolt against the whites, that the movement would spread to ocher tribes in kenya and eventually to a11 of East Africa and the Congo. 98 one of the leaders of the Mau Mau mentioned that although he had in the past tried to achieve change through estabiished channels such as politics andi trade unions, opportunists acting in their own interests nad negated all his attempts.99 He ielt that since peaceful methodis had not been successful, it was necessary to impor: advice, equipment, and arms.100 This led to the involvement of Russians. A Russian, unofficially meting with the leaders of the revolt, referrad to the 1917 Russian revolution and ics outcome remarking that one of the major results was equality of all the survivors. The leaders planned to accept the aid from Russia. They did not think

$$
\begin{aligned}
& 96 \text { Ibid., p. } 56 . \\
& 97_{\text {Kuark, Somethirg of value, p. } 429 .} \\
& 98 \text { Ibid., p. } 325 . \\
& 99 \text { Ibid., p. } 313 . \\
& 100 \text { Ibid., p. } 313 .
\end{aligned}
$$


they were making any comitment to the Russians. 101 However, the Rusians imagined

. how pathetically easy it would be with England gone and three hundred different trikes makirig war on each other, to walk in and bring order out of chaos...

All you cyer needed was just a little simple nationalism and a fer oid customs to pervert when you dealt with simple peopie, and they would do most of the dirty vork theinselves.102

Another: source of material aid was those Indians of East Africa dissatisfied with English treatment j.n all aspects of their economic, social, and legal 1ife. The Indians had also seen that the people in India were at last successful in their fight for independence.103

\section{Ruark ciescribed the scenes of Mau Mau destruction} and asserted that Africans love destroying. In each Furopean household attacked, those responsible vere often those Africans whose positions were relatively important or close to the Europeans.104 Not only Europeans were killed, but also those Kikuyu who would not take the oath, who would not become members of Mau Mau, or who would not aid the Mau Mau. 105

$$
\begin{aligned}
& 101_{\text {Ibid. }}, p \cdot 314 . \\
& 102_{\text {Ibid. }}, p \cdot 325 . \\
& 103 \text { Ibid., p. } 313 . \\
& 104 \text { Ibid., pp. } 409,425-26 . \\
& 105 \text { Ibid., pp. 427-28. }
\end{aligned}
$$


During the first muths of the revolt, the European settlers felt that the uprising constituted a var. I'he British government fol a long while proceeded under the assumption that the settiers were exaggerating the situation and that the conditions would return to normal. The majority of the settlers thought it was not possible to deal with the worsenjig situation through law. These settlers wanted to retaliate in a like manner--"We'll chop a head or so, and burn a few villages, " for they felt that the Africans were "a flock of dirty murderers." The uprising was considered initially to be a "...tribal thing and the ray to stamp it out is to really pitch into the old kikuyu and show him a thing or two about terror."106

Robert Ruark did not seem to place the blame on either one side or the other.

Whose fault all of it was didn't make any real difference now. You couldn't blame children for playing with matches and burnj.ng down the house, and you couldn't blame the man who made the matches, either. But after that you tried to keep the matches out of the reach of the child.j.07

In 1954 Elspeth Huxley's A Thing to Love was pub1ished. At this time the fighting between the guerrilla

$$
\begin{aligned}
& 106 \text { Ibid., pp. 436-37. } \\
& 107 \text { Ibid., p. } 592 .
\end{aligned}
$$


forces and their wite settler opponents was a coristant element in the political and military scene in the country in which this author had lived and about which she had primarily written. The author presented a number of ideas concerning the causes ard growth of Mau Mau througin the various characters in this tale. Through the characters, one can see some of the strands winch have contributed to weaving the cloth of Mau Mau.

Sam, a settler, while returning to kenya, pictured a black Kenyain traveler as believing

...that all the troubles, frustrations, and evils of the world--his [the African] world, anywa--would vanish like smoke if only he and his tribesmen could have thejr country to themselves, go back to the days when their dark forests kept out all people, all chasges,

Then, miraculously, would dawn an age of prosperity and easy living, ar age in which men respected one another. The Africans would do anything to achieve this. The settler believed that the Africans would destroy the improvements the Western civilization had brought to the Africans. 1.09

Sam pictured Pat, a teacher in a rission who was a daughter of a settier family, as

108 Elspeth Huxley, A Thing To Love (London: Chat to and Windus, 1954) p. 16.

109 Ilid., p. 16 . 
...druming a lot of useless norisense into those black. wolity heads--turning out future prostitutes and swollen headed youths who thought themselves too grand for mand work and went to sweil the rarks of spivs in the town. 110

The missionary couple who headed the school held certain standards to be absolute ard the need to inculcate a sense of standards overriding. The root cause of African poverty, fickleness, and impatience was the weakness in the African character expressed the principle: "Let's make that do." 111 In adition, they felt that poverty was due to the fickleness and impotence of the Africans. The root cause was not, as the Africans claimed, exploitation by whites. The missionaries also were very concerned about preventing female circumcision for they felt it was a bartarous custom.112

Another young settler farmer criticized not only the mission schools for the African children's lack of respect for people including their elders, but also the independent schools whose teachers he claimed had "...been kicked out of the inissions for immorality or stealing." These independent school teachers taught only sedition.113 Following an

$$
\begin{aligned}
& 110_{\text {Ibid. }}, p \cdot 26 . \\
& 111_{\text {Ibid. }}, p \cdot 144 . \\
& 112_{\text {Ibid. }}, p \cdot 144 . \\
& 113_{\text {Ibid. }}, p \cdot 30 .
\end{aligned}
$$


argument with one of the men who worked for him, the settler's herds were slashed with pangas.

Some had their feet cut off and some were hamstrung and puljed themselves round vith their hind legs useless and sone were cut open and wälked about with their guts hanging out, bellowing. Il

The settler felt that the persors who were responsible were filled with hatred.115

The settler complained that although there had been evidence that there would be difficulties, the government had done nothing to control the situation.1.16 However, Pat felt that urban growth "...or great discontents--stifle the life within them [the Africans], the spirit in the seed, so that they didn'i grow but simply rotted inside."117 Although she

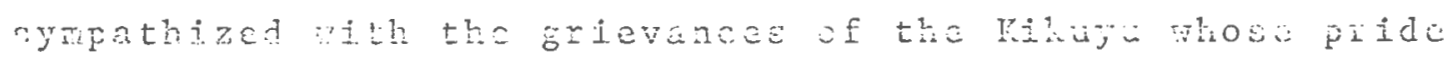
had often becn hurt, she felt that "...a conspiracy founded on hatred by seekers after power and built up by intimidation, couldn't be the arswer."118

Her father opined that ruch of the material in certain publications was written by dishonest urban Africans whose only interest was their own profit. The material was

$$
\begin{aligned}
& 114 \text { Ibia., p. } 74 \\
& 115 \text { Ibid., p. } 141 \text {. } \\
& 116 \text { Ibid., p. } 144 \text {. } \\
& 117 \text { ILjd., P. } 6 \mathrm{C} \\
& 118 \text { Ibid., p. } 64 \text {. }
\end{aligned}
$$


believed by the squatters and the people who lived on the reserves and led to increased agitation which would only profit a few. 19 He felt thar some of these agitators had received "instructions from the communists."120 The increase in the rate of crime bothered hin. He attributed those disturbances to Africans who were working for their own personal interests. 121

I.t seemed that the Africans viewed the Europeans as Having all the porver and position and control of African lives. It was difficult for most sett]ers to realize that what they expected for themselves was also desired by the Africars. The AIricans did not see a structure of society awong the Eurcpcans thich produced poor Firopean feople. The poor people in the country were Africans. Perhaps if the African had experienced seeing poor Europeans, he would have not become so bitter. However, he on]y saw Europeans as people who held the wealth and control. of the country. He could only attribute his own position to the fact that he was an African. He realized that the country was not being run in his interest.

119 ILId., p. 66 .

120 Ibid., p. 27.

121 Ibid., p. 144 . 
Sam's ex-vife, when talking to an African clerk, remarked about the problem of the lack of housing and of the poor housing provided: "I suppose it's the same everywhere, the housing shortage, I mean. I believe there are íailies of English people living in old army huts and bicycle sheds at home," to which the clerk replied: "But not in Kenya." 122

African oppositior to the settiers and the government was not united. Some of the Africans felt that those who were opposing the settlers and the government did not comprehend their own actions and the "forces they rad cha1lenged." However, Europeans had only a superficial knowledge of the Africans; the Furopeans believed themselves to be very superior to these Africans. 123

Although the movement was directed against Europeans, especially the English in Kenya, there were other Furopean countries willing to aid the movement for various reasons. 124 As a result, according to Miss Huxley, this confrontation was not completely an internal kenya affair. The aid was not

$$
\begin{aligned}
& 1.22 \text { Ibid., p. } 43 . \\
& 123 \text { Ibid., p. } 47-48 . \\
& 124 \text { Ibid., p. } 53 .
\end{aligned}
$$


only moral. but also material. With the acquisition of this aid, the members in control of the movement desired to attack imediately "... while the Furopean still sleeps like a man who has gorged himself. on beer and meat." Many of those in control of the movenent believed that violent action agairst the government and settlers was necessary. The leaders had long before resolved to "...speak with the voice of the government." People had started to question: "What has become of that ímous movement? It is mere talk after all like the KCA? What has happened to the knives and simis [swords]? Where are the dead Europeans they spoke about?" 125

Some of the African agitators tried to obtajn the alienated lanas and Independence from the turopean oriented goverment. These agitators demanded the restoration of traditional religion and customs.126 There seemed generally throughout the novel the concept that the Africans were revolting against the Europeans and the government primarily in order to return to the time before the arrival of the Europeans. There was no concrete plan for governing and structuring the society which had been altered by its contact with western culture.

125 Ibid., p. 55 .

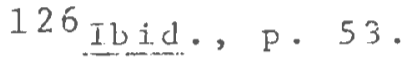


In order to rit the country of the Europeans, the Mau Mai planred that men would form guerrilla forces in the forests. These forcas were to harrass the sectlers and the government forces violently. These tactics were to draw the white troops and loyalists into the corests where the forest fighters or guerrilla forces veie to hold an advantage over them. This would be very costly for the government both in terms of men and material. Without the many kikuyu who had pledged support to the Mau Wau, the European settlers suffered. The kikuyu labor force was no longer arailable to the Europeans. Consumed with fear of the destruction of possessions ard of the murder of family members, the Europeans would leave Kenya. "Then at last the whole of Kenya would bejong to the kikuyu, who, as liberators, would be able to command the other tribes."

As more and more Africans joined the movement they were initially united through the oath and thus became 127 acquainted with the plans developed in order to gain "that power, wealth, and the enjoyment of their ancient customs."12.8 one of the oathing ceremonies so necessary for unity was described as taking place in an atmosphere which was designed

$$
\begin{aligned}
& 12.7 \text { Ibid., pp. } 159-60 . \\
& 128 \text { Ibid., p. } 58 .
\end{aligned}
$$


to unite the Iiving with their ancestors. This particular oathing caremony Encorporated the use of sheep. A Iong strip of flesh from the underside of the sheep's body from neck to tail was cut. When this was completed, the people who were to be oathed crawied through the customary arch of banana leaves. The oath administrator prayed.

Lut it seemed to many present that any god must have turned his head ana from the events that followed, when each in turn, in full public eye, lased his manhood for a putpose no god had ever intended. For surely gods had mada... the act of procreation to concern the living not the dead and to devour the source of life must be an ultimate profanity for which no man should hofe for pardon or forgetfulness. These acts would forever remain in their memory.

Each participant's commitment through the oath, forced or not, was irrevocable, whether or not he agreed with the. activities and ideals of the Mau Mau. izg While the participants ate the sacrifice they swore:

"If I am crdered to kill a European, I will do so and not turn back... If. I. am told to steal a gun, I will do so, and not turn back... If I am told to maim a European's cattle, I vill do so, ard not turn back... If I am told to burn a European's crops, I will do so, and not finch.... If any man who has eaten this oath asks for help I will give it to him at all times... If I am told to kil] an askari I will. do so, and take his gun.... If J reveal this oath to any man or woman, I shall die."130

Those who refused to take the oath, were usually tortured and kijled. These tortures included severing parts of

$$
\begin{aligned}
& 129 \text { Ibid., p. } 193 . \\
& 130 \text { Ibid., p. } 193 .
\end{aligned}
$$


the body. Some of thosi who refused to take the oath were Christians, especialiy, ministers. While dying after being tortured by Mau Mau, one African minister was told that he was considered to be a "white Kikuyu" for he had adopted so many European practices and ideas.131

Some Africans, who had accepied the fact that Europeans had taken over control of the country berause of their strength, began to question how effective and just that strength vas. The government seemed to do nothing to prevent the perversion of customs and laws and the death of innocent people.132 The European religion which had been preached was viewed by Africans as a device for controlling the population for they did not see the Furopears destroyed for disobedience. 133

There ware many Africans who wera persuaded to give money to the "conspiracy" by promises made by the leaders that they would receive land, position, or power when the Africans were able to get rid of the Europeans and were able to assure control and restore the customs of ancestors.134

$$
\begin{aligned}
& 131 \text { Ibid., p. } 233 . \\
& 132 \text { Ibid., p. } 173 . \\
& 133 \text { Ibid., p. } 184 . \\
& 134 \text { Ibid., pp. 185, 212-3.3. }
\end{aligned}
$$


reople who had been loyal. to the nuropeans would be "destroyed". Some of the Africaria felt they were trained, ready and able to assume control. They feit that the Europeans would not have been able to survive and obtain their power without the assistance of the Arricans. 135 However, some of the Airicans still felt a dependence upon the Europoans for their technology and medicines.136 some Africans felt that the conspiracy would not solve anything; it would bring only more trouble and would benefit only the leaders.137

The attention of the European settlers seemed to be primarily or the horrible attacks by the Mau Mau, both on Europeans and loyal Africans. There was little mention of the treatment meted out by the kenya settlers, servicemen; and loyal. Africans to the people they suspected of being Mau Mau and of planning and executing attacks, or of aiding and abetting Mau Mau. The author described some of the attacks: Kimani's head smashed to pulp, the seared backs of Matthew and Njombo, the bloody fragments of the Foxley, living children with their feet cut off, dying women with their bellies slashed to drag the embryo out of the womb.138

The attackers were described as being desperate and depraved

135 Ibid., pp. $76-80$.

136 I.bid., pp. $120-123$.

137 Ibid., Pp. 120-123.

138 Ibi.d., p. 244 . 
men. Miss Mringy's pottrayal. ot tha Mau Mau vas unsympathetic. Apparently, she felt the Africars rere not justified in their demands for greater participation in the eccnomic, political, and social structures of kenya. Although she might have been willing to consider some moderate demards, sine felt most of the leaders were either criminals or dishonest persons working for their own interests. The only way these leadere were able to obtain support was by forcing allegiance through the horror of the oathing ceremonies. 


\section{CHAPTER VI}

\section{BLACK NOVELS}

As of the present time, few black Africans have Witten novels in which Mau Mau and the Emergency have been incegrated or in which comments about the Mau Mau have been incorporated. East Africa has not experiensed the same modern literary development which West Africa has. Possibly, this was aue in part to the attitude of the Kenyan colonial government toward black education. Universal primary education was not provided for blacks. A very limited number of black students who completed primary school successfully were allowed to continue to secondary school. Of those who completed secondary schooling a relatively small proportion were able to continue their studies. Opportunities for Africans ior higher education were not provided by the gcvernuent. Educational facilities were linited in Kenya. In Eact, a number of Europeans sent their children to Great Britain for their high school education as well as university. Presently, Nairobi University College is the only degree granting institution in kenya. Therefore, the majority of kenyans must seek higher, cducaticn in other countries, e.g. United Kingdom, U.S.S.R., the Unjted States. Less than 
fiftean percent of the black chjldren who complete primary school and sit for the primary school certificate are able to gain admission into secondary school at the present time. However, the government is devoting j.ts energies to this probI en.

In the main, before Independence, sfrican children attended missionary schools. These schools were racially segregated. The missionaries felt it was their duty not only to provide Western education and reljgion but also to eradicate most customs and traditions of the African society through their African students. As a result, students were instructed to implant Western ideas and customs into the tribe and to encourage tine tribal members to abandor traditions.

Some Africans may prefer not to acknowledge their feelings held during the Mau Mau conflict and, therefore, will not write about this particular period. They may feel that the current world image of Kenya's stability would be shaken if further revelations about that tumultuous period were made. They nay not want to jeopardize their own present positions. By constantly bringing this period to the attertion of the nation and the world, the government's struggle to develop a sense of national unity would be extremely hindered. It is possible that the government is not encouraging materials to be writcen about the period. 
Each of the novels examined in the following pages was written by a Kikuyu. cif all the tribes, the Kikuyu had the greatest percentage of peopje participating in, affected by, or controlled by the Mau Mau. They had the greatest contact with the Suropeans and the Energency. More kikuyu are educared and $k_{2}$ ve becone influential in tine independent government, than persons of the numerous other tribes in Kenya. The Kj.kuyu are also the largest tribe in Kenya. In 1964 the first black novel about the Mau Mau emerged, Weep Not Child. James Ngugi, the author, studied writing at Makerere University, Uganda. He has written for one of the major kenyan newspapers The Nation and is a professional writer. In 1965 and 1969 , Weep Not Child was followed by Ngugi's The River Between and A Grain of Wheat, respectively. In all of these novels, the characters were affected by and involved in the tensions of the period of the Emergercy. The black men who had fought in the second World War had seen whites killing whites and had had sexual relationships with white women. Almost from their arrival in Kenya, the whites had tried to implant the idea that they were gods. The war completely'shattered any such illusions that the biacks may have had. ${ }^{1}$ The black soldiers were

LJames Ngugi, Weep NoL Crild (Londou: Heinemann Educational Book, Ltd., 1964) pp. 5-12. 
trained and ordered by the British officers to kill whites, albeit Germans and Italians. The blacks were forced to fight Hitler who in their eyes had "...not wronged" them. They were forced to"...save the British Empire from defeat and collapse."2 A qumber of Africans were killed in combat. The futility of war was evident. Why. should blacks have to participate in the white man's war? Why should they have to die for the white man's cause?. Why should they have to defend the British Empire and thereby help perpetuate colonialism? ${ }^{3}$

Some Africans wondered why the British had left Europe and had comé to Kenya.4 The majority understood that the whites were drawn by the promise of a good life. The colonial. government's expropriation of the most fertile land for Europeans caused irritation and hostility among the Africans. Many b1acks were forced to work for the settlers on the alienated 1 and in order to pay taxes imposed by the government. Many people were forced off land on which their families had lived for generations. The reserves which were overcrowded were the only place to which these dispossessed people could go. Others were allowed to cultivate a small fractior of

2 J.bid., pp. $64-65$

${ }^{3}$ Ibid., pp. 5-12.

4 Ibid., pp. 4-5. 
their forme: iands in raturn for working for the settlers.5 The settlers believed that the blacks had no rights to the alienated jands. They felt the land rightfully belonged to themselves. One settier expressed the idea in tive following fashion: "lhis is my land." The blacks realized that because of both the quantative and qualitative wealth of the lands the white men held, the Europeans were

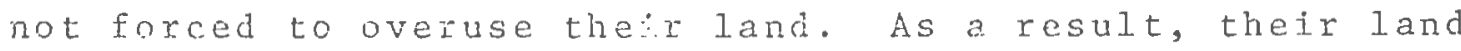
remained feztile and yielded abundant quality crops and 1ive stock. Because the blacks held so little land, in relation to the population, it was overused. The yield frotr the land held by a black family would generally not even provide subsistance and would provide nothing ior trade. The situation was described by one of the African characters in the following manner: "You could tell the land of the Black People because it was red, rough, and sickly, while the land of the white settlers was green and not lacerated into small st:ips." 7

5 James Ngugi, The River Between (London: Heinemann, 1965) E. 72 .

$$
\begin{aligned}
& { }^{6} \text { Ngugi., Weep Not Child, p. } 145 . \\
& { }^{7} \text { Ibid., p. } 8 .
\end{aligned}
$$


"Would these people never go?" This was the cry within the heart of every African. An old Kikuyu seer who had prophesied the coming of the Furopeans had also claimed that they would eventually leave. ${ }^{8}$ However, this seer believed

...you could not cut the butterflies [he had prophesied that the settlers' ciothes would resemble butterfly wings] with a panga [an African machete used primarily for gardening]. You could not spear them until you learnt ard knew their ways and movements. Then you could trap, you could fight back.9

Within the tribe and within individuals a conflict gradually developed whether to rid the country of the whites directly by fighting or by learning their ways through education. 10 some blacks believed that preparation for "the recovery of the lost londs" was the primpry or only value of Western education. 11 However, others believed that education would provide a better life and adopted the Western faith as wel1 as education.12 Many of Ngugi's characters advised that it was vital to learn everything the white man knew and to understand the white man and his ways. Many Kikuyu

$$
\begin{aligned}
& 8 \text { Ibid., p. } 36 . \\
& { }^{9} \text { Ngugi, } \text { The River Between, pp. 22-24. } \\
& 10^{\text {Ibid., }} \text { pp. 109-10. } \\
& 11_{\text {Ngugi, }} \text { Weep Not Child, pp. 43-44. } \\
& 12^{\text {Ibia. }, ~ p . ~} 55 .
\end{aligned}
$$


children were sent to missionary schools in order to becone "... wise in the affairs of the white man."13 By 1946 , many biacks, includifg those who had returned from the war, were concerned with their role in the country's future, the problems of unemployment, as well as the return of the 1and. Men wanted to work in their own interests and not to continue working in the interests of the whites. 14 Some of the men who were unable to Iind jobs and who had no 1 and went into politics to seek possible solutions to both personal and the Africans' problems. 15

$\vec{L}$ and was the major issue of conflict between whites and blacks. As previously discussed in Chapter Three, the Kikuyu particularly conceived of lard as a major link between past, present, and future, 16 and as the primary form of wealth.17 Land performed physical and spiritual functions. It was the altar upon which to offer a sacrifice to Ngai.18 On almost all points concerning the kikuyu concepts of land Leakey and Ngugi agreed. According to Kikuyu custom, land

${ }^{13}$ Ngugi, The River Between, pp. 44-45.

${ }^{14} \mathrm{Ngugi}$, Weep Not Child, p. 57.

${ }^{15}$ Ibid., p. 64.

${ }^{16}$ Ibid., p. 59.

17 Ibid., p. 22.

18 Ibid., p. 84. 
could not be bought or sold without placating the ancestors. As traditional ceremonies had not been performed when the Europeans took control, the blacks did not feel that the land ownership had bëen officially and properly transferred.19 Sometime between. 1946 and 1952 , during a political rally, a speaker reminded his listeners that the land given to their ancestors by $\mathrm{Ngai}$ had been taken away through religion and force. "The Bible paved the way for the. sword."20 Missionaries had been sent in advance to prepare the way for the coming of the settlers. 21 The settlers had found little initial resistance, but their influence which continually spread like ripples in the water was of a destructive nature.22 The missionaries had preached to the blacks of the necessity of their laying "...treasures, in heaven where no noth would corrupt them." Meanwhile, each settler had "..1 aid his on earth." 23

Upon the return of black soldiers to Kenya from the First World War in which they had aided the British troops, they found that the colonial government had given their lands

19 Ibid., pp. 68-69.

20 Ibid., Pp. $64-65$.

${ }^{21} \mathrm{Ngugi}$, The River Between, Pp. 74 and 125.

22 Ib L I. , p . 83 .

23 James Ngugi, A Grain of Wheat (London: Heinemann, 1967), P. 18. 
to the British soluiers in lieu of monetary payments. 24 Many blacks $3 y$ the end of the First World war wero iviter with their aldass, whom they blamed for allowing the white Inan to take control. initially.25 protest against government policies was organized by kariuki and other jmportant Kikuyu. This protest against the policies of taxation, land alienazion, black salaries had begin immediately after the First World War. Kariukj was arrested for his involvement in the activities. With his arrest the Africans', especially the kikuyus', hopes of success in forcing the Europeans to change policics had diminished notably. 26 Later other tactics were developed by the blacks to express their discontent with the attitude and practices of the settler and the settlec-oriented government. One of these tactics was to be a strike which would include all black persons in the employ of Europeans and the government.

The Government and the settlers had to be shown that black poople were not covards and slaves. They, too, had children to feed and to educate. How could people go on sweating for the children of the white man to be well-ted, well-clothed, and well-educated?27

$$
\begin{aligned}
& 24 \text { Ngugi, Weep Not Chj1d, pp. 64-65. } \\
& 25 \text { Ibid., p. } 17 . \\
& 26 \text { Ibid., p. } 47 . \\
& 27 \text { Ibid., p. } 58 .
\end{aligned}
$$


By the mid-1940 $\mathrm{s}$, Africans were becoming increasingly aware of independence movements elsewhere in the world, e.g., Gandhi fighting for Indian independence from British control.28 The Kikuyu in their attempts to alter their situation looked to Jomo Kenyatta for leadership and conceived of him as Moses. He had been delegated by God to free them from the control of the white man. They felt that since Harry Thuku had not succeeded, he would be able to bring into action the words found in Exodus 8:1:

And the Lord spoke unto Moses Go unto Pharaoh and say unto him, Thus saith the Lord,

Let my people go. 29

Even after his arrest and the declaration of the Emergency the people bolieved that Kenyatta would eventualy succeed for "God would not let his people alone."30

The KAU was a black organization which wanted "Wiyathi" [Freedom], return of alienated lands, higher salaries for blacks, and the abolition of the color-bar. The blacks' secondary position in the society was due to the imposition of the color-bar by the. government and the settlers. 31 Laws were passed by the settler-oriented government ${ }^{28} \mathrm{Ngugi}$, A Grain of Wheat, pp. 95-97, $102,109$. 29 Ibid., pp. 16,37 . ${ }^{30}$ Ngugi, Weep Not Child, p. 81 .

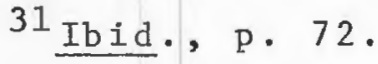


which supported the European take-over of 1 ands and the control of the blacks. ${ }^{32}$ In spite of the rumber of laws governing the blacks, the whites often took the law into their own hands. Their actions were directed by their attitudes towards the blacks. ${ }^{3} 3$ one of the few whites portrayed in Weep Not Child conceived of blacks as savages deserving little more consideration than animals. "He [the settler] wquld reduce everything to his will. That was the settlers" way." 34

When Kenyatta was arrested, many Kikuyu who had been working for indépendence had to decide whether to take a chance of being arrested or whether to join the guerrilla forces which were forming. 35 one young black who joined the Mau Mau forces gaid that the purpose of Mau Mau was to regain stolen lands. He felt it necessary that some die in order that the Africans break the control of the white man and gaj.n freedom. 36 Dedan Kimathi was designated as the head of the Freedom Army, while Kenyatta was described as the head of KAU. It was suggested that although these two groups

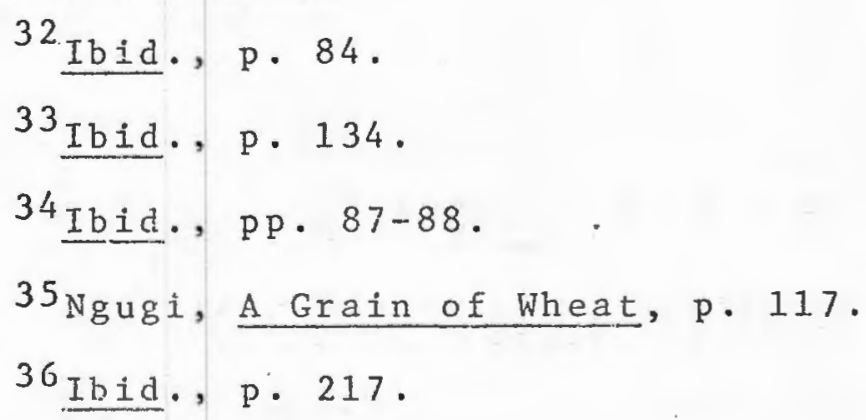


and their heads may have had different tactics, they had the same aim. That aim was the "freedom of the black people." 37

Those Kikuyu who were detained by the government agreed not to divulge any information about Mau Mau. "How could anybody reveal the binding force of the Agikuyu in their call for African freedom?" They felt that endurance in the African cause would lead eventually to success. 38 Those detained as well as others discussed plans for the future when freedom was won and Iands regained. These inciuded pláns for education, agriculture, and government. 39 Ngugi portrayed the disruptive and destructive effects of the white man's presence, attitudes, and laws on the Kikuyu society. As a result of the white man's presence, the blacks experienced shame and humiliation in almost all aspects of living. It was felt by many Kikuyu that the white man was able to control the blacks only because "he rules with the gun, the lives of all the black people of Kenya."40 With the spreading influence of the missions and

${ }^{37}$ Ngugi, Weep Not Child, p. 82.

${ }^{38} \mathrm{Ngugi}$, A Grain of Wheat, p. 121 .

39 Ibid., p. 124 .

$40_{\text {Ibid. }}$ p. 112 . 
settlers, the members of the tribe became increasingly concerned with preserving the integrity and the purity of the tribo.

As conitions did not seem to improve, many people began to take the oath of allegiance to the purity of the tribe. "Nobody could break this oath. Noboay who had taken it would ever betray the tribe." Beliefs in the power of the oath was so great for some people that they believed that "everybody who takes the oath of Unity to change things in Kenya is a Christ."41 However, some of the Freedom Fighters beljeved that some kikuyu would not keep secrets about the Mau Mau without taking the oath. 42

one of the major aspects of the tribal life which came into immeiate contact and confict with western ideas was religion. The imposed Western religion took into no account the traditions of the tribe. There was no stability in a society which was not allowed to maintain roots in the past.

A religion that took no count of people's way of life, was useless. It would not satisfy. It would not be a living exferience, a source of life and vitality. It wouid only main a man's soul, making him fanatically cling to whatever promised security, otherwise he would be $10 \mathrm{st} .43$

$$
\begin{aligned}
& 4.1 \text { Ibid., p. } 110 . \\
& 42 \text { Ibid., p. } 218 . \\
& 43 \text { Hgugi, The River Between, Pp. 162-63. }
\end{aligned}
$$


The missions' insistent attempts to rid the African society of the practice of female circumcision was to have many repercussions. The kikuyu could not understand the missions' condemnation of female circumcision for the Bible did not even mention this practice. 44 The missions did not provide something of value when trying to eradicate many traditional custors. Circumcision was important not only physically, but was primarily important psychologically, socially, and educationa11y.45 The missions did not realize its significance and importance. They consideredit barbaric and against religious tenets. 46 For the tribe, circumcision was an important ritual.

It kept the people together, bound the tribe. It was at the core of the social structure, and something that gave meaning to a man's life. End the custom and the spiritual basis of the tribe's cohesion and integration would be no more. The cry was up. Kikuyu Karinga. Keep the tribe pure... It was a soul's cry, a soul's wish.47

Uncircumcised girls were not pure. Their inpurity would displease ancestral spirits who might seek to punish the tribe. To the tribe, the death of a circumcised Christian

$$
\begin{aligned}
& 44 \text { Ngugi, A Grain of Wheat, p. } 100 . \\
& 45_{\text {Ngugi, The River Between, }}, 163 . \\
& 46_{\text {Ibid. }} \text { pp. } 26,30,42 . \\
& 47_{\text {Ibid. }}, \text { p. } 79 .
\end{aligned}
$$


girl was a warning of the ancestral spirits to the tribe to adhere to traditional customs and religion. 48 To the mission the death confirmed its point of view. Circumcision had to be stopped in order that there would be any hope of African selvation. 49

Almost all grievances of the Africans were connected with the presence of the wite man. It was felt that if the country were rid of the white man that in many cases the probleins would be jmmediately solved. Not only did people want to be rid of the power and control of the white man over their Jives, they wanted to develop self-expression through political independence. 50 one of Ngugi's principle characters, a teacher and regjonal leader in the tribe, was caugh in the conflicting forces developing prior to the outbreak of hostilities. He realized that people wanted "expression at the political level" and that "education for an oppressed people is not a11."51

One of the major problems which had to be overcome by the Kikuyu and the other African tribes was disunity. A number of leaders had to concentrate on unifying the people in their fight for the return of the lands and for political

$$
\begin{aligned}
& 48 \text { Ibid., p. } 62 . \\
& 49 \text { Ibid., pp. 63, } 65 . \\
& 50 \text { bici., pp. 135-36. } \\
& 51_{\text {Ibja. }}, p \cdot 160 .
\end{aligned}
$$


expression. This meant unification was necessary, e.g.

among Christians, and non-Christians, peoples of different areas. It was imperative to unify through education, for only through unity was it possible to obtain political Ereedom. 52

In $A$ Grain ot Wheat James Ngugi develoged several European characters to a greater extent than in his previous novels. One who had come to Kenya as an adininistrator was the head of a detention camp in which a number of prisoners died due to mal-treatment. He had conceived of his coming to Kenya as' part of a mission of the British Empjre. He was "...convinced that the growth of the British Empire was the development of a great morai idea."53 The British Empiré was to be based on the concept of equality of all men. The empire woulc include persons of all races and creeds. This adninistrator believed that

...to be English vas basical1y an attitude of mind; it was a way of looking at life, at human relationships, at the just ordering of human society. Was it not possible to reorientate people into this way of life by altering their social and cultural environment? 54

52 Ibid., p.p. $1.39,147$.

${ }^{53}$ Ngugi, A Grain of Wheat, p. 62 .

54 Ibid., pp. $62-63$. 
Later during the Mau Mau, this administrator was to write that it was necessary for the Europeans to use violence in trying to bring the Mau Mau under contro1. It was imperative that the Africans support the government. He opined that "Mau Mau is evil; a movement which if not checked will mean complete destruction of all the values on which our civilization has thriven." 55

Godwin Wachira, prior to working on the staff of The Nation, had been a politician and had been involved with the formation of trade unions. His first novel ordeal in the Forest was concerned with the effect Mau Mau and the Emergency had on the kikuyu. Wachira contended that many circumstances had contributed to the development of Mau Mau. Education was conceived of by some of the elders as a means of eliminating the humiliations and indignities which the Africans experienced in their relationships with the settlers.56 The Africans were treated like dogs and were considered to be "black apes". 57 Even the young children were aware of these experiences and some, full of hate,

$55_{\text {Ivid., pp. } 64-65 .}$

${ }^{56}$ Godwin Wachira, Ordeal in the Forest (Nairobi: East African Publishing House, p. 168) pp. 1, 28.

57 Ibid., p. 41. 
planned revange.

It [the land and the cattle] is ours, we'11 get it back off those white men, even if it means war... these Whites will suffer for what they have done to us, and so will their children and their children's children. We will make them creep and crawl in front of us. 58

The European settlers continued to operate under the assumption that they were the masters and they intended to remain so.59 The Europeans were little aware of the hatred and loathing they inspired by their attitudes and practices. The Europeams considered the Africans to be "... Iittle better than animals $60 \ldots$ black rats... [who] don't understand our [European] language. They haven't the brains for that."61 As the Africans tried various means of expressing their discontent. the settlers hecame increasingly more frightened about the stability of their positions. They were concerned, for they felt that they and their families had invested so much time, money, and effort.62 In spite of their material interest in the aspects of the country which provided profit and superior existance, the settlers knew little about and cared little about the thoughts and ideas

$$
\begin{aligned}
& 58 \text { Ibid., p. } 7 . \\
& 59^{\text {Ibid. }}, \text { pp. } 55,58 . \\
& 60 \text { Ibid., p. } 47 . \\
& 61_{\text {Ibid. }}, \text { p. } 55 . \\
& 62 \text { Ibid., p. } 59 .
\end{aligned}
$$


of the kikuyu. Very few of them could speak or read the vernacular. They did not undersiand that freedom had meaning for the Africans.63 The Europeaus felt that they were teaching the Africans a civilized way of 1 ife. ${ }^{64}$

The bIack men who joined the British troops during the second World War. learned that although their white masters had tried to convince them otherwise, they were not superior and their God did not protect them to any greater extent than the blacks. The freedon fighters, many of whom were members of the "Age groups of 40", vowed to reclaim 1.ands and wir freedom for their country. However, in order to win more members, leaders of the age group of 40 said that only those Europeans who refused to leave would be killed.

The Africans were weary of trying to cbtain their lands peacefully-- they had asked the government to return them and were refused.65 The Africans felt that they "...must chase the white man off our [Africans'] soil. This is our land."66 When approached about the issue of 1and the Europeans replied "...they want their country. Their country! We have nade it ours." 167

$$
\begin{aligned}
& 63 \text { Ibid., pp. 62-63. } \\
& 64 \text { Ibid., p. } 67 . \\
& 65 \text { Ibid., pp. 23-29. } \\
& 66 \text { Ibid., p. } 139 . \\
& 67 \text { Ibid., p. } 139 .
\end{aligned}
$$


Another issue was soil conservation. The Africans questioned the procedures, believing that they were another form of persecution. The settler-oriented government required the Africans to dig trenches on the African-held lands. The law was erforced brutal1y. However, in the lands held by the Furopeans these trenches were not required. Africans, especially after the Second World War, were required to dig trenches in an attempt to prevent soil erosion in the reserves. The reserves tended to be located in hilly and semi-fertile land. The government, in an attempt to raise the subsistence level, had instituted these schemes. 68

Religion was an important aspect of the African society. The Europeans controlled or tried to control the African spirit by trying to convert the Africans to Christianity. The missionaries' opposition to many African religious practices and to female circumcision were bones of contention. The missionaries would not accept the explanation of the tribe about the significance of ceremony of circumcision. "If we die uncircumcised we cannot go to join our ancestors." 69

$$
\begin{aligned}
& { }^{68} \text { Ibid., pp. 30-31. } \\
& { }^{69} \text { Ibid., p. } 31 .
\end{aligned}
$$


In an attempt to preserve their identity and selfrespect and to reduce the white man's control, the Africans developed several tactics. The oathing ceremony was designed to unite the Africans against the Europeans. The oathing ceremony was traditional, but the Freedom Fighters altered it. By taking an oath the Kikuyu were assured that the oath taker "...no longer be the white man's stooge but a worker for freedom."70 The oathing ceremony was described as incorporating the sacrifice of a lamb. Its blood symbolized "...the blood which would be shed in fighting." The drinking of the blood signified that the oath taker "... would never give up the fight. for freedom until the last wite man has either left the country or been k.j11ed."71" In addition, the oath taker had to promise to obey the leaders, to not divulge any information to people who had not taken the oath, to make any sacrifice required.72 After the Declaration of the State of Emergency people who had not taken the oath were forced to do so because the leaders felt this would prevent betrayal.73

70 Ibid., p. 74.

$71_{\text {Ibid., p. } 77 .}$

72 Ibid., pp. 77-78.

73 Ibid., pp. 106-109. 
The Europeans, in order to keep their positions of power secure, often used laws to tileir own advantage. 74 They even perjured themselves. They felt compelied to retain their superior positions under any circumstances and through any means. 75 Before the Declaration of the State of Energency, inany of the settlers tried to persuade the government to allow them to shoot all the trouble-makers. The Declaration Iurther convinced the Africans that the white man intended to retain his position of control. This increased the Africans' desire to gain independence. They had confidence in their leaders to gair the dignity and the freedom which they had been denied. With the Declaration of the State of Emergency,

.. the utter injustice of the Government and the brutality of the settlers towards any man with a biack skin was beginning to cause a blind hatred which hit anywhere and anyhow. The Africar was inore determined than ever to wipe out the cruel oppression at any cost. The Governirent's action, especially in arresting the leaders, caused the whole freedom movement to snap out of control.76

The Emergency prevented many traditional aspects of Kikuyu life from continuing. For example, the communal system of living which was the essence of their existence was brutally prohibited. 77

$$
\begin{aligned}
& 74 \text { Ibid., pp. } 37,170 . \\
& 75 \text { Ibid., p. } 49 . \\
& 76 \text { Ibid., pp. } 98-99 . \\
& 77 \text { Ibid., p. } 98 .
\end{aligned}
$$


Many Europeans attributed the uprising to outside intervention and conceived of it as "...a war on a nationa1 basis rather than a local Kikuyu uprising."78 However, one would be led to believe that the author thought that there was no intervention from abroad and that it was purely a Kikuyu-European conflict. Not all the people who joined the forces in the forest joined because they agreed entirely with the aims and the tactics of the Mau Mau. However, for many the forest seemed to be the only sanctuary; the only practical decision was to join the forest forces. Following a raid by the forest forces the security forces would arrest, interrogate, and torture the young people of the viliage. l'hese security forces assuned the character of "Jords of creation". If the African members of the security forces conceded openly that they supported the government, the freedom fighters would attack their families. The forest forces were not peacefully unified. Many resented the fact that they had to obey young leaders. 79 The morale of the fighters decreased as the number of defectors to the government increased. As they lost men, their admissions requirements became less stingent. Consequently, many of the new

$$
\begin{aligned}
& 78_{\text {Ibid., pp. 107-08. }} . \\
& { }^{79} \text { Ibid., pp. 174-75. }
\end{aligned}
$$


nembers of the forces were actual1y spies. 80 There was increased competition among the leaders.81 A few of the forest leaders came to the conclusion that they could best serve the irterests of their people by leaving the forest and by working direatly with their people. They began to feel that they were not able to accomplish anything consiructive in treir forest forces as they had hoped. 82 Those who were captured by the security forces were subjected to various degrees of mental as well as physical torture. Many Kikuyu suffered, withether or not they had becone members of the forest armjes. In addition to the sufferings brought about by the various methods of torture by the security forces, many siffered for they were not sure what position they should take and how their actions would affect their families.83

Wachira commented that although the forest fighters seemed to have lost, the fight proved "...to be the decisive point, the point where the white man started to think about our Uhuru [Ereedon]. "84 The Kikuyu had begun to realize that when the physical fight had not realized its aims it was necessary to develop an underground movement and forma

$$
\begin{aligned}
& 80 \text { Ibid., p. } 178 . \\
& 81 \text { Ibid., p. } 181 \\
& 82 \text { Ibid., pp. } 217-18 . \\
& 83 \text { Ibid., p. } 221 . \\
& 84 \text { Ibid.. pp. } 280-81 .
\end{aligned}
$$


political party. Through politics and pressure, world opinior would oventual1 force the colonial government to grant independence. 85

Ali Africans were not united against tine Europeans. Some remained loyal to the government, to the settlers, and to Christianity. However, many of those who opposed the Europeans' practices and policies, blamed their elders for allowing the Europeans' to settle in Kenya. The blacks had initially accepted the whites on the supposition that the whites were to remain temporarily. The Europeans cane with the intention of settling permanently. The Africans were exposed to an alien culture but were given limited acess to it. The Europeans had no interest in the African cliture except to the extent of forcing changes of those practices which were not in the settlers' interests or which to them vere repugnant.

In a few material aspects, e.g., education and medicine, the Africans benefitted from the presence of the Europeans. However, everything the Furopeans provided was to serve the Europeans' jnterests, the Africans believed. Many elements of the Africans' culture including the political, sociological, and economic structures were destroyed by the

35 Iidd., PP. $280-87$ 
Europeans' or government's policies. Those aspects of the European culture which were superimposed on the Africans were not relevant to the Africans' experience and life. The Africans had neither their own culture nor the Europeans' culture in which to function and operate.

The Africars were humiliated by the European attitudes and practices. Their attempts to reach a reasonable, moderate settlement with the Europeans concerning participation in the government, society, and economy were frustrated constantly by the Europeans. The European reticence and lack of sensitivity to the Africans' interests and feelings exacerbated the conflict.

These African novels indicate that the Africans were forced into assuming a position of violence by the policies and practices of the Europeans. However, there was hope for the future. Violence would not completely solve the problems which had been brought about by the presence of the white man. Change might be brought about eventually through politics. Mutual understanding between Europeans and Africans would be essential. 


\section{CHAPTER VII}

\section{CONCLUSIONS}

The preceding chapters have examined a number of interpretations of the Mau Mau. Each author's conceptualization of Mau Mau--its development, causes, tactics--was greatly affected by his background, his educational, sociological, and more particularly, his racial background. Differences in racial background explain the basic misunderstandings, points of view, attitudes, and interests.

one becomes are that there were basically two points of view: that uf the white, $i$ e., the white settier, the European, the American on the one hand, and that of the black Kenyan on the other. As a rule, until the decade of the $1960^{\prime} \mathrm{s}$, the world was exposed almost exclusively to the views of the whites Ipt only in the literary forms (personal memoirs and novels) which have been examined in this study, but also through other media such as movies, news, papers, magazines, radio, and television. All these media during the Energency were directed to white audiences. Actual1y, the exposure through television during the Fmergency was limited because relatively few persons had television in the Urited States and Europe. Television was not available in Kenya. However, klevision has become an importait 
vehicle for projecting several movies during the last decade.

The blacks' viewpoints were not afforded a similar exposure through all these media. Access to the media and the media themselves were controlled by whites both within Kenya and without, especially during the Emergency. In addition, the blacks who were involved in Mau Mau or detained did not usualiy have an environment and materials condusive to recording events and ideas. Although some of the alleged Mau Mau members as well as those loyal to the government were literate, much history among African tribes was still not preserved in written form. The past was transmitted through the spoken word. People were accustomed to learri of situations, policies, and events by word of mouth. Retribution, not always deserved, wight have been inflicted upon those blacks who had decided to try to publish during the Emergency, either by the government or by the Mau Mau. The government and the settlers would have been extremely suspicious of any black writing. Even if works had been completed, the blacks would not have had access to publication. One point which must be considered is that none of the books examined which were written by blacks have directly criticized the Mau Mau. However, there is concern with violence. None of the black writers examined was loyal to the government. Most of the black authors were not actively 
involved in or did not actively support Mau Mau. They straddled the fence and ostensibly supported neither the government nor the Mau Mau.

As distance from an event, measured in terms of time, increases, the objectivity of an author generally increases. When writers experience the pain of having friends and relatives murdered violently it is difficult for them to be objective. One fact that must be kept in mind is that the novelists were not concerned primarily with providing accurate information. One must be fully aware of the fact that the whites were writing during the Emergency. The effect the events had on their interpretaticn, no doubt, was enormous, especially in those cases where they were writing before the heat of the conflict had diminished. In the novels and personal memoirs written by the whites, readers are exposed to the concept that the Mau Mau were excessively violent. This was partiy because the information concerning the Mau Mau attacks, activities, and combat was purveyed by the government and disseminated through the white grapevine. A fewer number of whites proportionately were killed by the Mau Mau forces than vice versa. According to the statistics cited by Corfield in the Historical Survey of the Origins and Growth of Mau Mau, ninety-five Europeans, both civilians and members of the 
security foree were kilied while 11,503 Mau Mau were killed.1 Information about the incidents of the murders of the whites was used for propaganda purposes and as a rationale on the part of the whites. The settlers and their government must have feli that jit was necessary to save face in front of the watching wor 1 d.

In order to rationalize their own behavior and that of their government, the whites painted an extremely violent picture of Mau Mau. The enemy was pictured as concrete and tangible. Each black person was required to take a stand either for the government or for the Mau Mau. The whites warted to know defiritely whose interests the blacks planned to serve. Violence, in especially bizarreforms, produced a feeling of hatred for the perpetrators. Those white persons undecided about which rights the blacks should be given, were forced to choose the white's defensive pcsitior.

The whites needed to show why they were unable to overcome their enemy easily, although the former had the aid of Great Britain in the form of men trained in modern warfare, advanced weapons, and supplies. Many of the grievances of the blacks were the result of certain white attitudes and practices which were carried through governmental procedures. The whites needed to show that they had ample reason to fight.

1.T. D, Cotfield, Historical Survey of the origins and Growth of Mal: Mau (London: H. M. Stationary office, 1960 ), 
Violerice on the part of the blacks seemed to be the justim fication.

Violence, however, increased after the government declarec a state of Emergency. When the governinent declared the State of Energency, was there actually in existence a clear and present danger? Did the deciaration only verify an established situation and fact? Or did violence develop as a resuli of the harrassing tactics adopted by the goverilment? After the Emergency was declared, had violerce become a means of comnunication for the blacks? The blacks may nave viewed'violence as the only means that would convey to the whites their feelings and ideas. In return, the whites used violence as a means of reply. The whites did not want to change any of the situations, practices, and attitudes whish had produced the black violence. Both sides found themselves in a position of having to save face.

If the purpose of violence on the part of the blacks was to force change, it was not until much later that this purpose was served. One often sees that the violence was used or was interpreted as means not to force charge in the white paoplea' and the government's policies and attitudes, but to force the settlers to leave the country. If the settlers left the country, black people would have been free to function without white control and interests. The blacks were utjlizing force to bring about change, while the whites were utilizing force in an effort to naintain the status quo. 
The setclers and the world were so shocked at the violence because they could not comprehend what the blacks wanted. The white worlo has vieved colcnization as a policy which, although a burder to the mother country, was for the good of the colonized people.

Problems develop when one society determines what is gcod for another. The coiony was generally directed in the interests of the colonial power and not in the interests of the indigerous population. The whites felt that they had the right to determine the limit of the rights of the blacks. Although blacks had been exposed to the whites' practices and ideas, they had not been allowed to participate in the whites' society: economy, and government. Only the blacks' skin color prevented them from participating. If the white population and government were so concerned that the blacks were not educated sufficiently to participate, why were not educational facilities provided in sufficient qualj.ty and quantity? The few changes that had been introduced were brought about under great pressure ard in conjunction with increased power for the whites in other areas. Rebellion, sucir as Mau Mau, could only happen in those instances where the oppressor is in very close proximity to the oppressed and where the differences of position are artificially based on racial criteria. The Mau Mau primarily involvad those who had been in contact with white values. 
The wites themselves were aware that situations and people were changing. Many settlers were becoming increasingly aware that their positions and power were threatened by the seeds that had been sown throughout the twentieth century. The whites liad carried to all corners of the globe ideas and practices which were often contradictory, e.g., the rights of man and the superiority of the whites.

Whites wanted to preserve the status quo berause it served their interests.. The whites in kenya knew that their privileged positions did not rest on merit. They wanted no change except that which would increase their cortrol. Change, any change, which might force them to share rights would mean that they would no longer possess that which distinguished them from the rest of the society. A number of setilers had not been successful in their home countries. Others felt that their attempts to obtain a position had been thwarted by the establishment either because they did not come from the right families or receive education at accepted institutions. Still others had been given land in Kenya by the British government in payment for wartime services. In addition, there were people who were serving temporarily as representatives of the British government. Those Eurcpeans who had not been successful in their home countries had set up social, political, and economic barriers in order to elevate themselves into a position of artificial superiority. They were the people whose positions would be most 
atered. As a result tiley had to develop a violent rationale for themselves and the world.

Orie must remember that, in addition to the fact that the media and access to the media were controlled by the whites, the media were geared for consumption by whites. Materials were written in English. Therefore, the audience primarily was composed of those who knew Fnglish. In some instances, the materials were translated into the tribal languages or Swahiii by English-speaking Africans. Materials disseminated through radio and novjes required knowledge of English. Generally, whites were the only persons who could afford to own radios or to go to the rovies. Therefore, these media did not utilize the languages of the blacks.

in many instances, at ileast initlaliy, the sociological siructure predetermined by race may prevent persons of one race fror enotionally and intellectually appreciating and comprehending the others' practices, ideas, and way of 1.ife. This especially was true of the whites in Kenya. To a large extent, however, the blacks exhibited a great comprehersion for they, in many instances, functioned within the white system. The blacks were required to support that system while not being considered equal participants. The whites imported Western society to Kenya. To serve their own interests, they superimposed their society on the country. As far as the settlers and the government were concerned there 
was really no feason to understand the black society. The whites never worked within the blacks' structure. Blacks were bent to be subservient to the whites, but not to participate on equal footing in the white structure. The whites' knowledge of blacks was of a differert nature. Their behavior was not bent to the black structure. Their relationship with the blacks was external, $\dot{i} \cdot e .$, they did not function within the black society. On the other hand, the blacks' relationship with the whites was internal, in that they functioned in the white society, albeit at the command of the white. The' situation might be expressed in the following way. The whites allowed the blacks into their game. The rules, however, were different for each team. The whites were allowed to score. The blacks were not. In fact, the blacks in essence, were only to help the whites to score.

As the blacks functioned within the structure of the whites they became more knowledgable. When the blacks became the enemy they were far less fathomable for the whites. As a result they were viewed as a greater threat. The point has been made by some that a considerable number of the whites who had been relatively close to blacks were killed. Why? The whites' relationship with the blacks was often paternalistic. The blacks wanted no father figure in the white. Why were the missionaries so vulnerable? Africa, as other parts of the non-Western world. was opened first by the missionarles. Other interests, including commercial interests, 
supported the missionaries for introducing the christian religion, they introduced Western civilization, both the 1deological and material aspects of that civilization. The missionaries in Kenya were the first Westerners to offer educational facilities. However, they generally felt that the blacks would not be sufficiently prepared to participate in the white society and culture for a long time. Missionaries, purveyors of the Western culture, required that the Africans give up some of their unique traditions and adopt Western practices. The missionaries were so utterly convinced that their mission was to save the damned. They may not have been aware that their attack on tribal practices was not only destroving these practices but also the structure of the society.

When Christian missionaries were subjected to violence ard their practices questioned, Europeans reacted in extreme. The white God had been attacked by those who were damned. The concept held by the Kenyan whites was that they were providing an opportunity to the blacks for salvation from damation. The white world saw the attack on missionaries as well as on other whites as the total black rejection of the white society and the white power structure. In the main, the whites were not alarmed that the black rejection of the white society would result in a chatic situation if the whites were to leave. The whites werc primarily concerned that their interests would no longer be served. 
The hlacks saw that the survival of the white life style was dependent upon the blacks. However, the white was not necessary for black survival. Their way of life had been altered by the white. The whites felt they had contributed to the well-being of the blacks. However, although some facilities and sorvices, e.g., medical, were made available to blacks, at least on a limited basis, adequate provisions were not devised to take into account the consequences of such exposure. Also one must remember that when a society is exposed to the material aspects of another, the level of material expectation in the former radically rises. The people of developing areas of the world primarily desire to emulate others materially. Generally, they do not desire to change spiritual1y.

The existence of the color-bar permitted the inclusion of the black in the white system only to the point he served the white. There was, on the other hand, nothing designed to exclude the white from the black society. The white felt that there was nothing for the whites in the black society. There was nothing which forced him to serve in the black society. With the onset of the black attacks, the white man was unable to look to himself as the cause. He was not aware (or if he was aware, he did not care) of what his presence had done to the black. Without understanding the causes for black unrest, the whites felt compelied to stress the horror of the attacks. 
Especially in those instances of attacks on families, the blacks involved often worked for the family. In some instances, these people had been forced by Mau Mau to participate in the attack. The fact that the settlers came to believe that they were attacked by the own servants made the horror of the situation more intense. Not only then were attacked but whole families. Although many women and children had died during the world wars, the English families had not experienced death directly at the hands of the Germans, but through long range veapons which did not involve personal contact. The enemy was not seen and the enemy was not known during the world wars. The whites stiess their horror in the fast that the attacks were made by the Mau Mau, on a person to person basis, utilizing weapons which required direct contact. The blacks had not been considered able to organize themsalves to such an extent. The whites had not realized the intensity of the black frustration.

As far as literary value is concerned, one, of course, Is dealing with the age old situation of good versus evil, God versus the devil. The analogy carried to color, from the white point of view, would have white symbolizing goodness, God fighting to survive against the black, symbolizing evil, the devil. The blacks viewed the situation from the opposite point of view. In these instances, the color representation is carried to skin color. There could be no more simplistic 
manner of expression. What happenea to those blacks who supported the whites in this conflagration? Those blacks, as the Mau Mau expressed it, had white hearts. They were no longer considered by other blacks to be black because they had forsaken the black ideas and traditions while submitting themselves to the white man.

since the white writers were directing themselves to whites they realized their audiences would readily accept horror perpetrated by the blacks. The black writers seemed not to stress the horror so much. They were more concerned with the background and causes of the revolt. The horror they depict is not that of attack on families, but the tormert-mental, physicall, and spiritual--brought about by consistantly brutal treatment of individuals who had been captured by government forcles. The objective of the captors was to break the spirit of those captured, so they would no longer be biack in spirit but would become completely submissive to the will of the white.

The difference in depiction of horror would seem to be the result of the differences of outlook of each race toward the other. The white seemed to be concerned with physical attacks on his person and on his status quo. Although. the black suffered physical trutality, the black authors were more concerned with the effect on the spirit of the man. The fear of Mau Mau physical attack caused great emotional strain on whites. 
Although almost without exception the comments and attitudes expressed by the authors drew them into two groups-the biack and ine white--there was an area of grej exhibited ir some works. All the blame for the creation of the situation of the Energency was not laid completely at the feet of cne by the other. For exampie, one of the principle European characters jn Rodert Ruark's Sometling of value stated in the closing pages that part of the overall problem lay in the fact that the black customs and way of life had been taken away by the whites but had not been replaced by "something cf value".

The Europeans wished to maintain the privileged positions which they had structured. The Africans wished to regain the velued positions, rroperties, and respect vhich they had possessed prior to the arrival of the Europeans. Thus, basically both had similar desires. However, the difference lay in the fact that the Europeans' privileged positions were authorized and supported by the government's policies. The Africans initially attempted to realize their goals through established constitutional. channels. However, those channels were closed by the Europeans. Eventually, the Africans resorte to violence. They became thoroughly convinced that the Europeans wolid act only in their own interests. The government offered no alternative to the Africans when it declared a State of Zmergency. The Declaration sparker violence, it was not an answer to violence. 


\section{BIBL IUGRAPHY}

Bajdwin, William W. Mau Mau Man Hunt. New York: E. P. Duttor and Co., Inc., 1957.

Barnett, Doñld L., and Njama, Karari. Mau Mau from Within: Autobiograhy and Anaivsis of Kenya's peasart Revolt.

Bentett, George. Kenva: A Political History. The Colonial. Period. London: Cxtord University Press, 1963.

Bchannan, Pau1. Africa and Africans. Garden City, Neb York: The Natural History Press, 1964.

Carothers, J. C. The psychology of Mau Mau. Nairobi: Governmen't Printing, office, 1954 .

Corfield, 5. D. Histortcal Survey of the Origirs and Growthof Mau Mau. London: H. M. Stationary Office, Cmd. No. 1030, 1960.

Delf, Geotoe, aud kenyatta, Jomo. Towards Truth Áout "the Lisht of Kenya". Garden City, New York: Doubleday and Co., inc., i.961.

Gatheru, R. Mugo. Child of Two Worlds: A Kikuyu's Story. Garden City, New Iork: Doubleday and Co., Inc., 1965.

Hamilton, Mollie (M. M. Kaye). Later lhan You Think. New York: Cowdad-Macann, Inc., 1958.

Harlow, Vincent, and Chilver, E. M. (eds.). Historyof East Africs. Vol. rI. Cxford: Charerdon Press, 1965.

Henderson, Ian (with Phil-p Goojicrt). The Hunt for Kimathi. London: Pan Books Ltd., I962.

Holman, Dennis. Buana Drym. New York: W. W. Norton \& Co., Inc., $196 \overline{\bar{j}}$

Itote, Waruhiu. 'Mau Mau' Genera1. Nairobi: East African Publishing House, 1967 .

Jones, Denys. Look Not Upon Mo. New York: Criterion Books, 1.955. 

Kariuki, Josiak Mangj. Yau Mau' Detainee. London: Oxádord

Kenyatta, Jomo. Facing Mt. Kenya. New York: Random House, 1962 .

Leakey, L. S. B. Defeating Mau Mau. London: Methuer and Co., 1955 .

- Mau Mau and the Kikuyu. London: Methuen and Co., Lt d., 1952.

Majadalary, Fred. State of Emergency: Tle Full Story of the Mau Nau. Toronto: Iongman's, 1962 .

Mboya, Tom. Hreedom and After. London: Andre Deutsch, 1963. - The Kenya Question: An African Answer. Iondon: Fabian Colonial Bureau, 1956.

Monsarrat: Nicholas. The Tribe that Lost its Head. New York: William Sioan Associates, 1956.

Montfied, de Hcruri. Sous la Mascue Mau Mau. Paris: Gassett, 1956.

Ngugi, James. A Grain of Wheat. London: Heinemann, 196 ?. - The River Between. London: Heinemann, 1965. - Weep not Child. London: Heinemann Educationai Book, Ltd., 1964 .

Oliver, Roland, and Fage, J. D. A Short History of Africa. Baltimore: Penguin, 1962 .

Rawcliff, D. H. The Struggle for Kenya. London: Victor Gollancz, Ltd., 1954 .

Rosberg, Carl G., Jr., and Nottingham, Jahn. The Myth of "Mau Mau": Nationalism in Kenya. New York: Frederick A. Eraeger, 1966 .

Ruark, Robert. Sometring of Value. New York: Pocket Books,

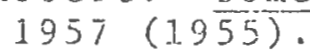

- Uhuru. New York: Fawcett World Library, 1962.

Sheraton, Neil. African Terror. Iondon: Robert Hale, Ltd., 1957. 
Wachira, Godwin: Ordeal in the Forest. Nairobi: East Africantpublishing House, 1968 .

Waciuma, Charitl. Daughter of Mumbi. Nairobi: East African fublisting House, 1969 . 